University of Louisville

ThinkIR: The University of Louisville's Institutional Repository

Electronic Theses and Dissertations

1939

\title{
The treatment of the factory in English novels, 1830-1914.
}

Clara Bell McLellan

University of Louisville

Follow this and additional works at: https://ir.library.louisville.edu/etd

Part of the Literature in English, British Isles Commons

\section{Recommended Citation}

McLellan, Clara Bell, "The treatment of the factory in English novels, 1830-1914." (1939). Electronic Theses and Dissertations. Paper 1831.

https://doi.org/10.18297/etd/1831

This Master's Thesis is brought to you for free and open access by ThinkIR: The University of Louisville's Institutional Repository. It has been accepted for inclusion in Electronic Theses and Dissertations by an authorized administrator of ThinkIR: The University of Louisville's Institutional Repository. This title appears here courtesy of the author, who has retained all other copyrights. For more information, please contact thinkir@louisville.edu. 


\title{
UNIVERSITY OF LOUISVILLE
}

The Treatment of the Factory in English Novels

$(1830-1914)$

\author{
A Dissertation \\ Submitted to the Faculty \\ of the Graduate School of the University of Louisville \\ In Partial Fulfillment of the \\ Requirements for the Degree \\ of laster of Arts \\ Department of English \\ by \\ Clara Bell McLellan
}

Year

1939 
Name of Student

Title of Thesis: The Treatunent of the Factory in English Novels (1830-1914)

Name of Director

Approved by a reading committee composed of the following members:

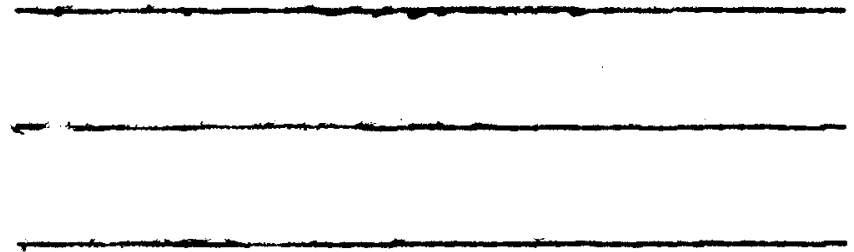

Representative of the English Department:

Datefomuary 1939 
THE TREATMENT OF THE FACTORY

IN ENGLISH NOVELS

(1830-1914) 
Then, in full many a region, once like this The assured domain of calm simplicity And pensive quiet, an unnatural light Prepared for never-resting Labour's eyes Breaks from a many-windowed fabric huge; And at the appointed hour a bell is heard-of harsher import than the curfew-kmoll That spake the Norman Conqueror's stern behest-A local summons to unceasing toil! Disgorged are now the ministers of day; And, as they issue from the illumined pile, A fresh band meets them, at the crowded door-And in the courts--and where the rumbling stream, That turns the multitude of dizzy wheels, Glares, like a troubled spirit, in its bod Among the rocks below. Nien, maidens, youths, Nother and little children, boys and girls, Enter, and each the wonted task resumes Within this temple, where is offered up To Gain, the master idol of the realm, Perpetual sacrifice.

From Wordsworth's Excursion, Book VIII, lines 165-185 
TABLE OF CONTENTS 


\section{CONTENTS}

Introduction

$$
\text { Page }
$$

Orerviow

4

Chapter I--The Problem of the Introduction of Machinery

Chapter II--The Problem of the Exploitation of Women and Children

Chapter III--The Problem of Labor Organization and Strikes

Chapter IV--The Problem of the Literary Effectiveness of the Novels 112

Conclusion 124

BIbliography 
INTRODUCTION 


\section{INTRODUCTION}

The treatment of the factory in English novels is a subject that has been curiously neglected. The only work that bears on this subject is an untranslated French study of the social novel in England from 1830 to $1850 .^{1}$

To limit the scope to factory conditions and to extend the time from the beginning of the nineteenth century to 1914, promised an interesting investigation which would shed light directly on the historical problem by ascertaining the response of the British mind to new social conditions, and indirectly, on similar contemporary problems, since the struggle between capital and labor is still going on today. Since 1914 or the World War period, however, the novelists have written for a different class of readers and their method of dealing with the problems has necessarily undergone a change.

In the nineteenth century, most of the novels dealing with factory conditions were "purpose" novels, that is, novels written to call attention to the need for social reform. They are primarily social pamphlets rather than literature. The aim of this investigation, therefore, is two-fold: first, to analyze the authenticity of these novels as social pamphlets, and secondly, to consider their literary effectiveness.

The materials for this investigation are first, twenty-five novels

1

Cazamian, Louis, Le Roman Social En Angleterre (1830-1850), (Paris, 1903). 
'about factory life,' and secondly, requisite background studies on the social conditions of the period. A few novels such as The Frobishers (1901) by Rev. Sabine Baring Gould, and The Master of Life (1913) by Sir Philip Gibbs, that might have boen helpful, could not be obtained. 2 Since most of the agitation and legislation until 1860 concerned textile manufacturing, it is not surprising to note that the factories in almost all of the novels I studied are textile mills. It is interesting that John Halifax, Gentleman (1865) by Mrs. Craik, whioh portrays the ideal man of the age from a middle-class point of view, also portrays the rise of the hero from an apprentice in a tannery to a manufacturer of a cotton mill. Of the total number of novels, sixteen have the factory in the foreground and are, therefore, partioularly revealing; the rest put character delineation to the fore and the factory to the background.

The major problem was to see if the picture presented by the novelists coincided with the development of the factory system as it was shown by historians.

The historical materials are: first, general histories such as Traill's Social England (1905). Cheyney's Introduction to the Industrial and Social History of England (1907), and White and Shanahan's The Industrial Revolution and the Economic World Today (1932), and secondly, monographs on the factory or factory problems such as Lincoln's The Factory (1912), "Alfred's"

1

Derived from Baker, E. A., Guide to Historical Fiction, (New York, 1914). Baker, E. A., and Packman, James, Guide to the Best Fiotion, (New York, 1932). Dixson, Z. A., Subject Index to Prose Fiction, (New York, 1897). Caramian, Louis, Le Roman Social En Angleterre (Paris, 1903).

2

Nelther the Louisville Free Public Library nor the University of Louisville Library could locate these books through the inter-library loan service.

Dixson, lists also two anonymous books, Strike in the B----mills, and Rival Apprentices, but no indication of date or place of publication is given and these books could not be traced to ascertain if they would be helpful. 
History of the Factory Movement from 1802 to 1847 (1857), Engel's Conditions of the Working Class in England 1844 (1887), and Webb's History of Trade Unionism (1894).

In the development of the factory there were three phases: first, the period from the end of the eighteenth century to about 1815, when the problem of invention and machinery was to the fore as a result of the Industrial Revolution; secondly, the period from 1802 to 1847 , when the exploitation of the women and children brought about the "factory acts"; thirdly, the period since 1846, when the problem of labor organization with its attendant strikes and violence was uppermost.

The novels illustrate these phases of historical development. Accordingly, each of the first three chapters deals with one of these phases. The fourth chapter deals with the factory novels as literature. An overview of the factory conditions with the novels pertaining to them immediately follows, particularly for reference in reading the first three chapters. 
OVERVIEW OF FACTORY DEVELOPMENT 
IMPORTANT HISTORICAL FACTS REDATE IATING TO FACTORY DEVELOPMENT

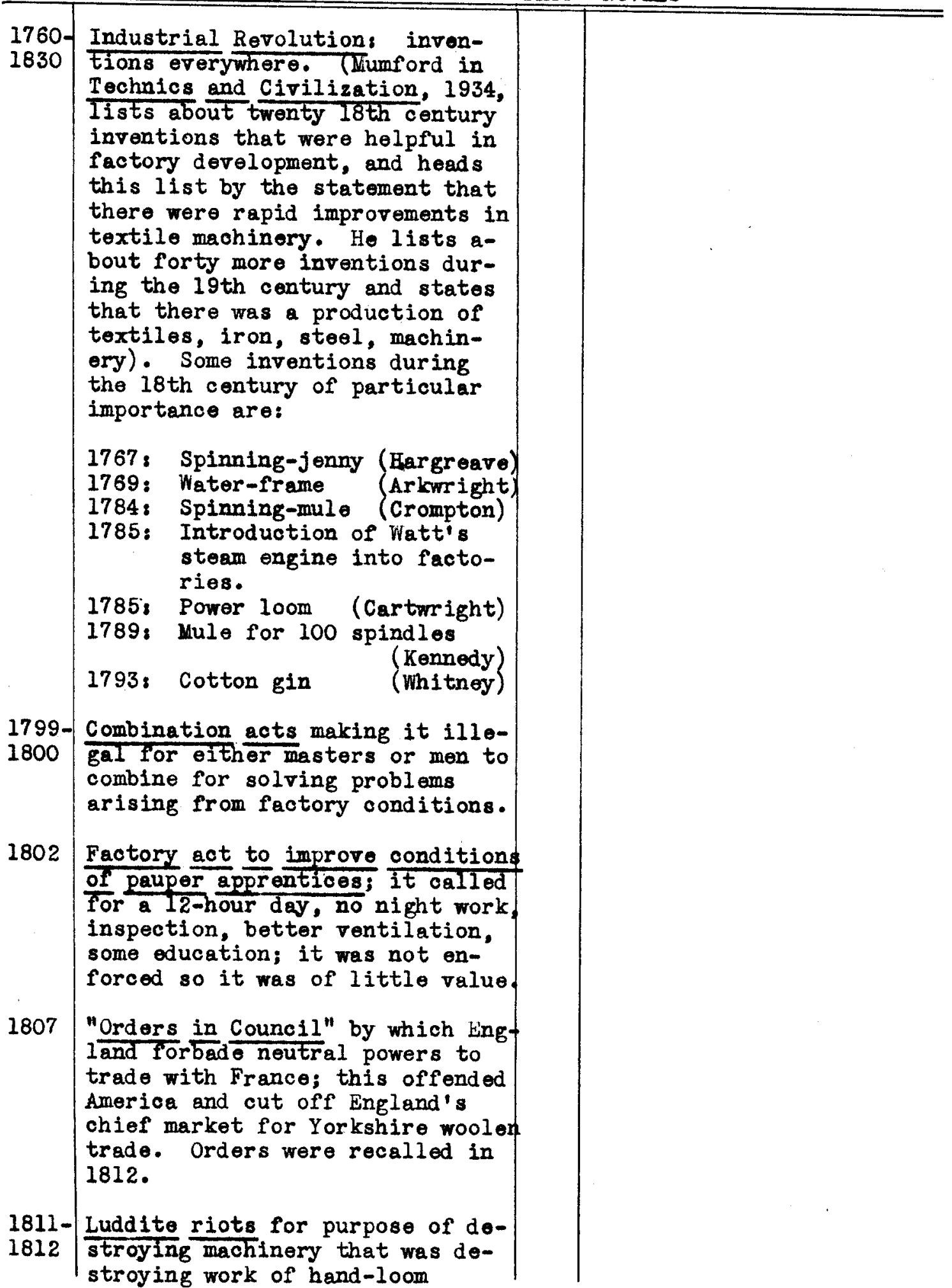
weaver 8 . 
1815

Corn laws forbidding importaEion of corn until English price reached eighty cents per quarter; these laws were responsible for the high price of food. They also restricted trade and lessened the manufacturers' markets.

1819

1824

1825

1825

1832
Factory act for all factory children; no ohild under 9 years to work in factory; those from 9 to 12 to work only 12 hours daily, exclusive of mealtime; administration of this aot was in the hands of justices of the peace.

Repeal of combination acts.

Act allowing workers to combine to talk over methods of better ing conditions, as long as meetings carried on quietly and orderly.

Factory act making a 12-hour day for those up to 16 years, with 9 hours on saturday.

Factory act making a 12-hour day for those up to 18 years, and no night work for anyone under 21 years.

Passing of Reform bill calling for a redistribution of seats in the House of Lords according to the population at that time. This gave more seats to the industrial towns, and more power to the middle or manufacturing class.

Factory act: children from 9 to I3 years to work not more than 48 hours a week; young people not more than 68 hours a weok; no one under 18 years to do night work; children 9 to 13 years must attend school; inspectors appointed to enforce act.
A Manchester Strike by Harriet Martineau; a narrative, not a novel, but important because it is the first fiction written about factory problems. 
Rise of Chartists with platform of universal suffrage, vote by secret ballot, abolition of property, qualifications for nembers of Parliament, annual elections, division of country into equal electoral districts, salaries for Parliament.

\section{Formation of the Anti-corn} Law League

Factory act making children work only hall-time, and making manuf acturers fence in dangerous machinery.

Repeal of the corn laws when famine threatened land; policy of free trade established.

Factory act, famous "Ten Hour Act," making a ten hour working day for women and children employed in factories.

DATE

Michael Armstrong by Frances Vilton Trollope, first novel that was written with the direct purpose of showing the mistreatment of factory children in the early part of the century.

1841 Helen Fleetwood by Charlotte Elizabeth Tonna, purposely written to arouse public sentiment against the exploitation of young women and children working in the factories.

Lary Barton by Elizabeth Cleghorn Gaskell, a discussion of the labor struggles from the worker's viewpoint.

Shirley by Charlotte Brontë, written about the period in factory development from 1810 to 1815 and shows a millowner's reaction to rioting and machine wrecking. 


\begin{tabular}{|c|c|c|c|}
\hline & & & \\
\hline 1850 & $\begin{array}{l}\text { Faotory act allowing mills to be } \\
\text { open only from } 6 \text { A. M. to } 6 \text { p. M., } \\
\text { Saturday only half time. }\end{array}$ & $\begin{array}{l}1854 \\
1854 \\
1856\end{array}$ & $\begin{array}{l}\text { North and South by Elizabeth } \\
\text { Cleghorn GaskeI,, a fairer } \\
\text { and saner discussion of the } \\
\text { labor situation than that } \\
\text { shown in Mary Barton. Both } \\
\text { the master's and the worker's } \\
\text { views are given. } \\
\text { Hard Times by Charles Dickens } \\
\text { written to denounce material- } \\
\text { istic viewpoint of middle } \\
\text { class manufacturers. } \\
\text { John Halifax, Gentleman by } \\
\text { Dinah Varia Muloch Craik, } \\
\text { written concerning period } \\
\text { from late eighteenth cen- } \\
\text { tury to about } 1810 \text {; a } \\
\text { character study of a middle } \\
\text { class gentleman, who rose } \\
\text { to be a mill-owner during } \\
\text { the troublous times of } \\
\text { machine-wrecking. }\end{array}$ \\
\hline 1861 & $\begin{array}{l}\text { American Civil War; great dis- } \\
\text { tress and famine in Lanceshire } \\
\text { because England could not ob- } \\
\text { tain cotton from the South. }\end{array}$ & 1862 & $\begin{array}{l}\text { Abel Drake's Wife by John } \\
\text { Saunders, primarily a char- } \\
\text { acter study of the young } \\
\text { wife of a leader of a strike } \\
\text { who later returns as an in- } \\
\text { ventor. Factory in the } \\
\text { background. }\end{array}$ \\
\hline
\end{tabular}

Employers' Liability Acts; employers to pay componsation for personal injuries to workers while in service at the mills.

Sheffield Outrages, notorious crimes or "rattening" arising from unionists' anger at lockouts. The explosion of a can of gunpowder in a workman's house in Sheffield aroused antagonism toward Trade Unionism.

Appointment of a Royal Commission, as a resuIt of sheffield outrages, to hear from representative workers as well as 
1871 representative masters regarding trade unions. Commission advised legal protection of trade unions, but opposed violence of union men either to employees or to fellow workmen. Formation of boards of conciliation and arbitration.

Act legalizing trade unions but forbidding even peaceful picketing.

Trade Union Act further extended: no action of a union was punishable unless same act was criminal if committed by a single individual.

New trade union formed based on. ideas of "Iaissez-faire."

Compulsory el ementary education
Put Yourself in His Place by Charles Reade, a denunciation of trade unions and violence by union men.

Mistress of Langdale $\mathrm{Hall}$ by Rosa Nete, a character study of a young girl who leaves her family home in a factory town, to live in the mansion of an eccentric aunt with whom her parents have quarreled. Not of importance in the development of the factory.

The Manchester Nan by Mrs. G. Iinnaeus Banks, a character study of a foundling, Jabez clegg, who became a partner in a manufacturing concern. It deals with the period before machinery.

Wenderholme by Philip G. Hamerton, a character study of the Ogden family, cotton manufacturers, showing the gradual degeneration of the two sons, the one from miserIiness, the other fror. drink. Factory setting, but not of importance in factory history. 


\begin{tabular}{|c|c|c|c|}
\hline 1878 & $\begin{array}{l}\text { Factory and Workshop Consolida- } \\
\text { tion } \text { Act; A factory code con- } \\
\text { taining a vast number of provi- } \\
\text { sions for the regulation of in- } \\
\text { dustrial establishments. }\end{array}$ & $\begin{array}{l}1880 \\
1881\end{array}$ & $\begin{array}{l}\text { Probation by Jessie Fothergill, } \\
\text { written concerning years from } \\
\text { l860 to } 1863 \text { when Lancashire } \\
\text { was suffering from a cotton } \\
\text { famine as a result of the Amer- } \\
\text { ican Civil War. Shows a kind- } \\
\text { ly mill-owner's method of } \\
\text { averting poverty. } \\
\text { The old Factory by William } \\
\text { Westall, } 3 \text { vols. tracing the } \\
\text { rise and struggles of a manu- } \\
\text { facturing family over a pe- } \\
\text { riod of about fifty years. } \\
\text { of particular interest in the } \\
\text { account of invention and ma- } \\
\text { chinery, of the master's } \\
\text { views as opposed to that of } \\
\text { the poor hand-loom weavers } \\
\text { during the years from } 1810 \\
\text { to l816. }\end{array}$ \\
\hline 1884 & $\begin{array}{l}\text { Reform Acts; franchise extended. } \\
\text { Parliament now represented whole } \\
\text { population, not just the aris- } \\
\text { tocracy and the bourgeoisie. }\end{array}$ & 1885 & $\begin{array}{l}\text { Through the Fray by G. A. Henty, } \\
\text { a story of the Luddite riots at } \\
\text { the time of bringing in of ma- } \\
\text { chinery. It is a juvenile book } \\
\text { but is historically correct. }\end{array}$ \\
\hline 1886 & $\begin{array}{l}\text { Rise of "new" trade unionism } \\
\text { that wanted an eight-hour day } \\
\text { by legislation, and municipal } \\
\text { organization of workshops. }\end{array}$ & 1887 & $\begin{array}{l}\text { Thyrza by George Gissing is a } \\
\text { character study of a superior } \\
\text { factory girl. It is important } \\
\text { from the factory standpoint } \\
\text { because the author portrays an } \\
\text { idealistic, cultured manufac- } \\
\text { turer with an interesting but } \\
\text { impossible idea of helping the } \\
\text { workmen by educating and rais- } \\
\text { ing the standards of a few } \\
\text { superior workers. }\end{array}$ \\
\hline
\end{tabular}




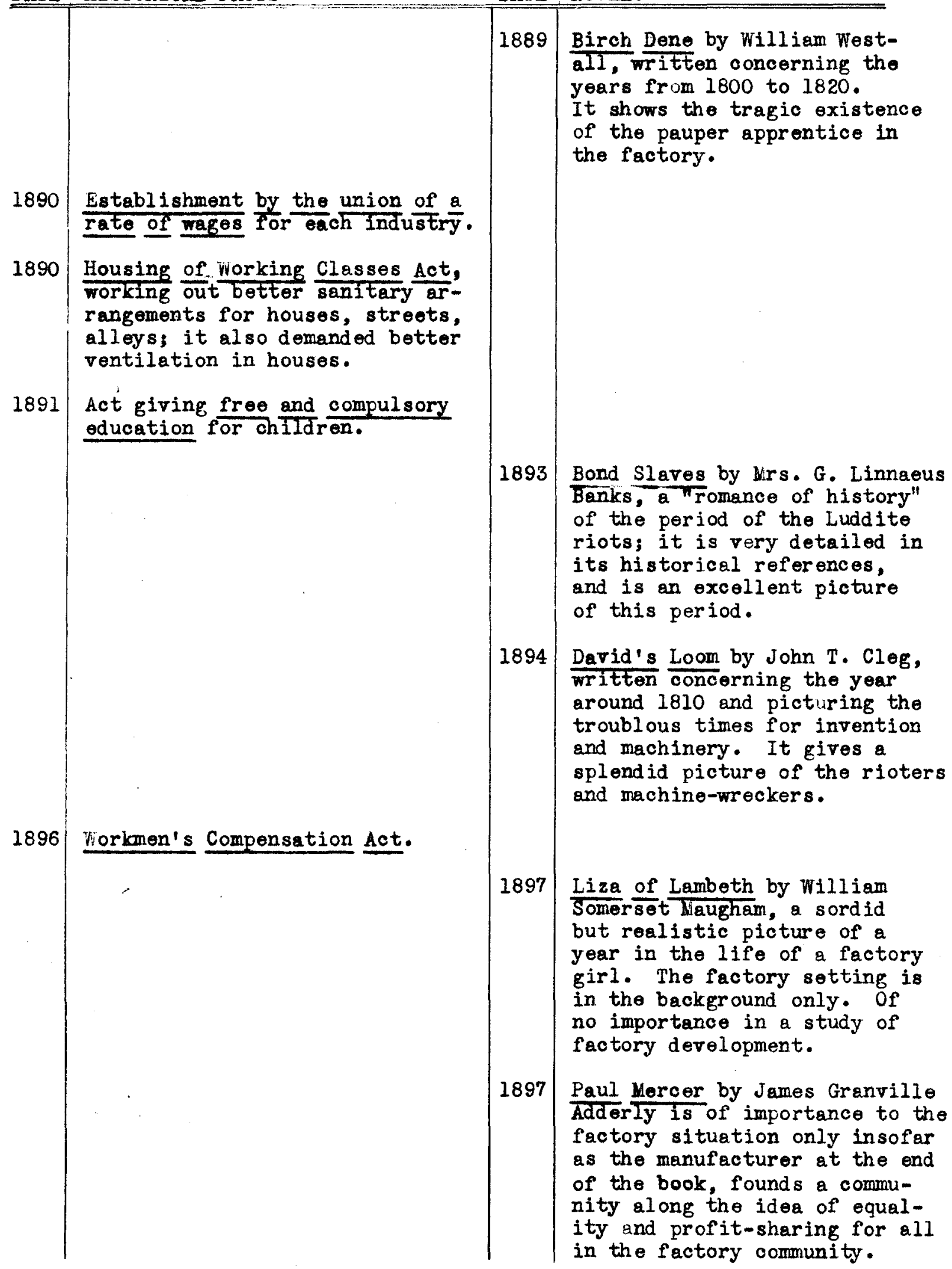


1901 Nistress Barbara by Halliwell Sutcliffe written about the period around 1825, and doals with the oppression of children in the factory, and the resultant unrest among the workmen resulting in strikes and hard times.

Forest Folk by "James Prior" (James Pryor Kirk), a story particularly of the reaction of farmers to machinery and land enclosure, but of some importance for a few statements concerning troubles in the menufacturing centers. It was written concerning the time of the Luddite riots, and is chiefly a character study.

The Story of Stephen Compton by John Edward Patter son, gives a sane and interesting account of the labor struggle towards the end of the ninetoenth century. 


\section{CHAPTER I}

The Problem of the Introduction of liachinery 


\section{CHAPTER I}

The Problem of the Introduction of Machinery

The first problem in the development of the frotory is that of the introduction of machinery. The overview shows the increase in the invention of machinery, the increase in food prices because of the corn laws and the "Orders in Council," the bringing of machinery into the factory, and the increased use of women and children in the factory. All of this caused a contention between capital and labor, and resulted in riots, bloodshed, and havoc. These riots were known as the "Luddite Riots."

No novels were written at the time of the riots partly because Luddism was a very secret organization, and partly because English literature had not developed sufficiently to begin a study of England's social problems. The novels that were written about the Luddite Riots appear after the middle of the century , and are all from a middle class point of view.

These riots were the outgrowth of the "Industrial Revolution." Various machinery such as the cotton-gin, the spinning jenney, the steam engine, the power loom, had been invented during the latter part of the eighteenth century and these brought about a great change in the industrial world. There were many changes involved besides

1

It is significant also that Gerhart Hauptmann's play The Weavers, which deals with the wearing conditions in Germany in the 1840's and $1850^{\prime} \mathrm{s}$, and treats the first crisis in German labor, was written in the latter part of the nineteenth century in 1892, and that Ernst Toller's play The Machine-Wreckers, which deals with the English Luddite Riots, was written in 1923. There is also, therefore, an interest in Germany in riots over machinery that corresponds to the interest in England. 
the adoption of machinery and artificial power, for a much greater amount of capital was needed, work was carried on much more extensively, and the scattered laborers were collected in well-organized, strictly-regulated establishments. This of course did not happen overnight but grew slowly from about 1760 to 1830 . It took time to perfect the machinery, to raise capital, to build factories, to organize labor, but

$$
\begin{aligned}
& \text { the men who had money and business ability } \\
& \text { applied the inventions of the eighteenth } \\
& \text { century and made large fortunes. But the } \\
& \text { time called for alertness and enterprise } \\
& \text { in business, and no manufacturer was like- } \\
& \text { ly to succeed who closed his mind to the } \\
& \text { new ideas.1. }
\end{aligned}
$$

Before these inventions, spinning and weaving were done at home in the cottages. The man worked the loom while his wife and children spun the yarn. Oftentimes an apprentice or two helped the family, but they all worked together using the simple machinery owned by the craftsman for making his cloth. Usually the family had a little land around the cottage which was farmed or used for pasture and thus they often raised their own raw material. There was, naturally, between the craftsman and those working for him in his little cottage, a warm, friendly feeling of kinship, and the craftsman was satisfied and contented even though he worked hard for long hours, for he was his own master.

But the advent of machinery brought about changes that the master craftsman in his little cottage did not understand and with which he could not cope. The hand-loom weaver could not compete with the machine, either in quantity or in quality. For generation the hand laborers, especially the weavers, kept up a desperate, miserable struggle for existence, but the result was inevitable; they either

1 Traill, H. D., Social England, Vol. V, p. 592, (Now York: G. P. Putnam's Sons. London: Casseli and Company, 1905). 
became agricultural laborers or went into the factories.

The period of transition from the domestic to the factory system of industry . . . was of almost unrelieved misery to great masses of those who were wedded to the old ways, who had neither the capital, the enterprise, nor the physical nor mental adaptability to attach themselves to the new. I

They were loathe to enter the factories or move to the cities but the spinners soon found it necessary; the weavers gathered around the factories and tried to eke out a bare living by working up the yarn which the master-spinners gave out. But the power loom even ended this effort of the weavers, and wages fell until the poor weavers were starved out.

Engels, a German historian who wrote on the conditions of the English class in the first half of the nineteenth century, was bitterly opposed to the indifference and parsimoniousness of the bourgeoisie or manufacturing class. He gives this interesting account of the hand-loom weavers:

I have been in many dwellings of such weavers, in remote, vile courts and alleys, usually in cellars. Often half a dozen of these hand-loom weavers, several of them married, live together in a cottage with one or two work-rooms and one large sleeping room. Their food consists almost exclusively of potatoes, with perhaps oatmeal porridge, rarely milk, and scarcely ever meat. Great numbers of them are Irish or of Irish descent. And these poor handloom weavers, first to suffer from every crisis, and last to be relieved from it, must serve the bourgeoisie as a handle in meeting attacks upon the factory system. "See," cries the bourgeois, triumphantly, "see how these poor creatures must famish, while the mill operatives are thriving, and then judge the factory system!" as though it were not precisely the factory system and the machinery belonging to it which had so shamefully crushed the handloom weavers, and as though the bourgeoisie did not

1

Cheyney, Edward P., An Introduction to the Industrial and Social History of England, p. 236, (Macmillan Company, New York and Lond on, 1907). 
know this quite as well as ourselves! But the bourgeoisie has interests at stake, and so a falsehood or two and a bit of hypocrisy won't matter much.l

These workmen felt they were persecuted first, because the machinery lessened the number of men required; secondly, because it cheapened their labor since they no longer needed to be skilled artisans but only guardians of machinery; thirdly, because they were no longer property owners or owners of their own looms, when they joined the factory workers; fourthly, because their years of freed om made them loathe the daily supervision and orderly, regular methods of the factories. Therefore, they destroyed machinery whenever it was possible. The years from 1811 to 1816 marked a siege of rioting in Yorkshire, Lancashire, and Nottingham by combers, spinners, and weavers who attributed their distress to the introduction of machinery. These rioters called themselves "Luddites" after a youth, Ned Ludd, a halfwitted boy who made himself notorious by destroying his father's stocking frames with a frame hammer. As a matter of fact, much of the distress of these workers was due to the long Napoleonic Wars and when peace was declared with France, prosperity also returned, and nothing more is heard of the hand-loom weavers, spinners, and combers. Nachinery took its place in factory development, and they took their places using the machinery in the fectories.

But these Luddite Riots following the bringing in of machinery furnish interesting material for novels, and they are the basis for six novels on the factory. None were written at the time of the rioting but date from the middle of the century until the beginning of the twentieth century. The novels are: Shirley (1849) by Charlotte Brontë,

1

Engels, Frederick, The Condition of the Working Class in England in 1844, p. 93, (John W. LoveII Co., New York, 1887). 
The Old Factory (1881) by William Westall, Through the Fray (1885) by G. A. Henty, Bond Slaves (1893) by Mrs. G. Linnaeus (Isabella) Banks, David's Loom (1894) by John T. Cleg, and Mistress Barbara (1901) by Halliwell Sutcliffe. The last novel mentioned is more concerned with the treatment of factory children than with rioting, but it gives an excellent picture of the hand-loom operatives. Three other novels mention the discontent of this period, but are more interested in showing character development than factory development. The first of these, John Halifax, Gentleman (1856) by Mrs. Dinah Miaria kuloch Craik, relates how the hero averts damage to his new machinery at a time when machines all around his factory are being destroyed. The second, Abel Drake's Wife (1862) by John Saunders, shows the difficulty an inventor encounters when he tries to get some manufacturer, during these hard years, to buy his invention. The third, Forest Folk (1901) by "James Prior," or James Prior Kirk, is about farm life and the smashing of farm machinery, but it gives some historical facts about happenings in the Nottingham factories and is interesting to show how machines were being wrecked in both towns and rural villages.

Although John T. Cleg wrote his novel, David's Loom, in 1894, it seems advisable to discuss it first, since it is the only one of the novels which deals primarily with invention, and is the only one which shows that the antagonism against machinery is so great that the workers will destroy the inventive efforts of one of their own number. After the discussion of this novel, the other books will be discussed in their chronological order.

In the novel, David's Loom, Cleg has an old crippled violinist who loved to dabble in literature write in his own way of the happenings in his town many years before. He uses an interesting method of having this oripple tell the story of his former friends David and 
Stephen Grindrod, exceptional weavers who stood alone for what they felt was right. Cleg shows how useless it was to oppose the advent of machinery, and how much more good than evil would result. Yet the novelist describes the suffering of these people, for he has David say of his neighbors:
"There's hundherds $i$ ' this teawn on th' very edge o' famishin'. We're o grund an' grund whol nobbut strong folk con live. Wakely chaps mun suffer an' dhrop, women an' childer mun pine to nowt."l

He then has stephen say:
"Our mates must be educated into full compre- hension of the laws of progress and we must count among the prophets and teachers they need. In their blindness they struggle against teachers; for what is the potent remedy to cure this pre- vailing misery--to make food cheap and money plentiful? Why, the very power loom they shatter and despise! 12

Cleg has these two characters work for ten long years on a power loom, and, at last, when it is finished, and difficulties surmounted, a crowd of ruffian neighboring weavers entered to break the loom.

The author shows us these grim determined men:

No friendly looks appeared among them now, for in their eyes Grindrod was a traitor to his degree and calling, a man to be summarily disposed of before his treacherous designs made more mischief than had been brought to pass already 3

He has David plead with them:

1 Cleg, John T., David's Loom, p. 30, (Longman's Green and Company, Lond on, 1894).

2

Ibid., p. 32 .

3

Ibid., p. 50 . 
"Think weel o'er what yo're beaun to do! This machine, simple as it stons here between us, has takken ten dhree year o' my life to make. Neet an' day aw've pondher't o'er it, an wrostl't forrad little bi little again sich hindhrance an' throuble as yo cawn't undhertond. Yo known me weel--aw'm no stranger comin' among yo to conthrive yor ruin--iv aw thought this invention could harm a mon here aw'd tak George's hommer an' breighk up mi wark misel afore yor $e^{\prime} e n$. Aw'm sthrivin' for yor good as weel as mi own, iv yo'd nobbut wit to gawm it . . It's idle for yo to feight again peawerlooms. They're bund to come--nay, they han com'n. They're in th' teawn to-day, an' getherin' o'reaund th' counthry side. What then? A loom's a loom. Whether it runs bi foot or engine peawer; machines wain't wortch beaut folk to mind 'em, an aw'll tell yo, honest an thrue, where there's one weighver wanted to-day there'll very soon be ten. Who's beaun to tent 0 these now looms? Why, who but us hondloom weighvers? What does it matther to us whether a frame's built o' timber or metal, whether it's gear't wi threddles or pulleys! Nowt, iv we con addle a wage-an' surelee to God we con ne'er be wur paid nor we han bin!"l

But cleg shows us the picture of the breaking of the loom and of David resolutely going on, determined to strive once more to accomplish his purpose to build a power loom that would aid his fellowworkmen. He then tells us how factories and machinery rose here and there and how

the bulk of our hand-loom weavers, trapped midway between old methods and new, prowled over the parish in clannish, discontended bands, workless, desperate, starving, disturbing public peace, seeing no remedy near or distant for their undoubted conditions of misery. Deprivation had touched its lowest bearable point with them--they could endure no more and live.2

Riots resulted, but machinery and factories sprang up and the fighting was useless.

${ }^{1}$ Cleg, David's Loom, pp. 52-53.
${ }^{2}$ Ibid., p. 79. 
The only remedy Cleg offers is to remove the ignorance and lack of understanding of the wealthier class of England. He has Stephen say to the rich Miss Seaford:

"This very lack of information which you acknowledge is the chief hindrance between us and you. Would to God you rich people could be induced to examine these questions for yourselves! Our homes are open to you. Within a hundred yards of this room I could show you sights to horrify your unsuspecting heart. Believe me, lady, if you and your kind throughout this island were but fully acquainted with the truths of this matter there would be no further cackle of market prices."I

The story is graphically told, but the master's side is not shown. Much earlier, in 1849, Charlotte Brontë wrote Shirley, a novel based on the Yorkshire life with which Miss Brontë had been acquainted from childhood. Probably, as in most of her books, the main characters are drawn from real life, but it is of interest in this study because the author tells of the mill-owner's efforts to introduce machinery into his clothmill in spite of the neighboring weavers.

She pictures the mill-owner, Robert Moore, as a quiet, intelligent, but determined man; a man who will stand by his trade, his mill, his machinery, though all other manufacturers are frightened by the seething anger of the mob. The story follows the fortune of Moore, not only in his business affairs, but in his love affairs, and shows his nature being moulded by contact with Caroline Helstone, whom he eventually marries. Noore's brother, tutor, marries the heiress Shirley Keeldar. Shirley, who owns the land on which Moore's mill is located, helps the manufacturer when trouble starts among, the weavers for she believes that firmness and preparation will prevent trouble from the workers.

1 Cleg, Darid's Loom, p. 67 . 
Miss Brontë describes the "Orders of Council" which forbade neutral powers to trade with France, and had, by offending America, cut off the principal market for the Yorkshire woolen trade. Minor foreign markets such as Brazil, Portugal, Sicily were all overstocked, and much cloth was piled up in the mills because it could not be sold. At this crisis, certain inventions in machinery were introduced which lessened the number of hands employed, and left many men without work or means of livelihood. Added to all this distress, the writer says, was that of a bad harvest, so that the misery of the people made them hate the machinery, caused riots and havoc for the manufacturers.

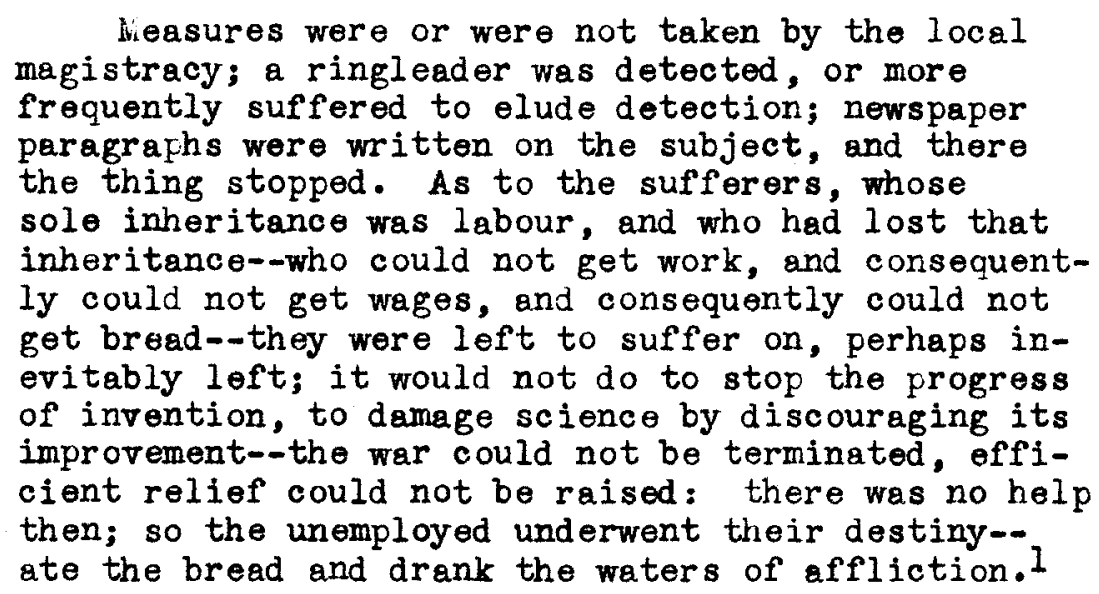

The manufacturer, had risked the last of his capital on the purchase of the new machinery, and waited grimly in his counting-house for the rioters.

Miss Brontë describes another type of mill-owner in the form of wir. Yorke, who sided with the operatives, did all in his power to relieve their distress, and was loved by his neighbors because he was kind and considerate. If he dismissed any workmen from an occupation, he would try to give them something else to do, or at least see that they and their families were moved to a district where they might get

1 Brontë, Charlotte, Shirley, p. 28, (Harper and Brothers, New York and Lond on, 1900). 
work. This man, the author, of course, uses as a mediator between the determined manufacturer and the sullen workers, and he often spoke with severity to the masters whom he felt were mainly at fault because they were indifferent to the suffering round about. Yet the author says she is not speaking of hard or cruel masters, of slave-drivers. The reader is forced to admire the outspoken Robert Moore whom the author makes address a delegation of workers in this manner:

"As to being dictated to by you, or any Jack, $\mathrm{Jim}$, or Jonathan on earth, I shall not suffer it for a moment. You desire me to quit the country: you request me to part with my machinery. In case I refuse, you threaten me: I do refuse--pointblank! Here I stay; and by this mill I stand; and into it will I convey the best machinery inventors can furnish. What will you do? The utmost you can do--and this you will never dare to do--is to burn down my mill, destroy its contents, and shoot me. What then? Suppose that building was a ruin and I was a corpse, what then?--You lads behind these two scamps, would that stop invention or exhaust science? Not for the fraction of a second of timel Another and better gig-mill would rise on the ruins of this, and perhaps a more enterprising owner come in my place. Hear me!--I'll make my cloth as I please, and according to the best lights I have. In its manufacture I will employ what means I choose. Whoover, after hearing this shall dare to interfere with me, may just take the consequences. An example shall prove I'm in earnest."I

Hiss Brontë realizes that at this point her readers will side with the manufacturer, and to counteract this, she has a good, peace-loring workman address the mill-owner:

"It's out o' no ill-will that I am here, for my part; it's just to mak' a effort to get things straightened, for they're sorely a-crooked. Ye see we're ill off--varry ill off; our families is poor and pined. We're thrown out $o^{\prime}$ work wi' these frames: we can get nought to do! we can earn nought. What is to be done? Nun we say, wisht! and 1 ig us down and dee? Nay: I've no grand words

1 Brontë, Shirley, p. 115. 
at my tongue's end, $\mathrm{Mr}$. Moore, but I feel that it would be a low principle for a reasonable man to starve to death like a dumb creatur',--I willin't do't. I'm not for pulling down mills and breaking machines: for, as ye say, that way 0 going on' 11 never stop invention; but I'll talk--I'll mak' as big a din as ever I can. Invention may be all right, but I know it isn't right for poor folks to starve. Them that governs mun find a way to help us; they mun mak' fresh orderations. Ye'll say that's hard to do: So mich louder mun we shout out then, for so much slacker will t' Parliament-men be to act on to a tough job."I

It is the answer the novelist has the mill-owner give to this sincere workman that makes the reader realize the severity, the unyielding attitude of some of the best of masters:

"If I stopped by the way an instant, while others are rushing on, I should be trodden down. If I did as you wish me to do, I should be bankrupt in a month, and would my bankruptcy put bread into your hungry children's mouths? William Farren, neither to your dictation, nor to that of any other, will I submit. Talk to me no more about mach inery; I will have my own way: I shall get new frames in tomorrow. If you broke these, I would still get more. I'll never give

And the author adds a comment on such a master who, by a kind word

to an honest workman, might have made a friend:

It seemed wonderful how he could turn from such a man without a conciliatory or a sympathizing expression. The poor fellow's face looked haggard with want; he had the aspect of a man who had not known what it was to live in comfort and plenty for weeks, perhaps months past: and yet there was no ferocity, no malignity in his countenance: it was worn, dejected, austere, but still patient. How could Moore leave him thus, with the words, "I'll never give in," and not a whisper of good-will or hope, or aid?

Miss Brontë has Moore get the aid of some soldiers, for she has him say:

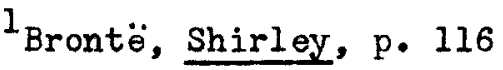

Ibid., p. 117

3 Ibid., p. 118
} 
"Our only plan is to be firm. I see that officient preparation and a resolute attitude are the best means of averting bloodshed."1

But this only held the mob at bay for a while. She shows the manufacturer selling nothing, running his mill on speculation alone, facing total ruin unless peace came to France speedily and the "Orders in Council" were removed. The author has Moore say that the workmen are in touch with those of Nottingham, Nanchester, Birmingham; that all the men are disciplined by their leaders:

"No blow is struck without mature deliberation - . The long-threatening storm is sure to break at last." 2

In this book, liss Bronte uses an outsider, shirley Keeldar, a wealthy young woman, as a stay and help to the mill-owner. Shirley not only invests some of her money in the mill to tide Moore over financially, but she discusses the situation with him, and by this method the novelist brings about a slow change in the demeanor of the manufacturer. hiss Brontë voices her own views when she has Shirley tell Moore:

"I cannot get out of my head a certain idea that we manufacturers and persons of business are sometimes a little--very little, selfish and short-sighted in our views, and rather too regardless of human suffering, rather heartless in our pursuit of gain." 3

He is made to listen to this young woman interested in both her welfare and that of the workmen, so that the author shows him cool, forbearing, and yet unflinching when the rioters come to attack his mill. His attitude is approved by the author, for she comments:

Moore had expected this attack for days, perhaps weeks; he was prepared for it at every point. He had fortified and garrisoned his mill, which in itself was a strong building: he was a cool, brave man; he stood

lBrontë, shirley, p. 209.

2Ibid., p. 243.

3 Ibid., p. 274. 
to the defence with unflinching firmness; those who were with him caught his spirit and copied his demeanour. The rioters had never been so met before. At other mills they had attacked, they had found no resistance; an organized, resolute defence was what they never dreamed of encountering. When their leaders saw the steady fire kept up from the mill, witnessed the composure and determination of its owner, heard themselves coolly defied and invited on to death, and beheld their men falling wounded round them, they felt that nothing could be done here. In haste, they mustered their forces, drew them away from the building, a roll was called over, in which the men answered to figures instead of names: they dispersed wide over the fields, leeving silence and ruin behind them. The attack, from its commencement to its termination, had not occupied an hour. 1

In 1856, Mrs. Dinah Nariah Wuloch Craik, wrote John Halifax, Gentlemen. In this novel, John Halifax, the hero, is confronted, about 1810, with the question of putting machinery in his mill. The workers, however, $\operatorname{lov} \theta$ and trust the master and quietly and peaceably watch for weeks the setting-up of the steari engine.

Mrs. Craik has Phineas, the cripple, say that perhaps it was because John loved his fellow men and dealt humanly with them that in the crisis that had been the destruction of so many mill-owners, his hands could look at him and say:

$$
\begin{aligned}
& \text { "He be a fine fellow, the master; he sticks } \\
& \text { at nothing." }
\end{aligned}
$$

And Mrs. Craik has the master start the machinery, and then let them crowd into the engine room, curious, wondering, while he explained stage by stage how the machinery worked until the more intelligent understood the working principle of the engine.

"But they all looked with great awe at the master, as if he were something more than man. They

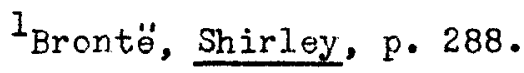

${ }^{2}$ Craik, Dinah Maria Muloch, John Halifax, Gentlemen, p. 319, (A. LeBurt, New York, n.d.).
} 
listened open-mouthed to every word he uttered, cramming the small engine room till it was scarcely possible to breathe, but keeping at a respectful distance from the iron-armed monster, that went working, working on, as if ready and able to work on to everlasting. 1

And the author has John Halifax pay full wages to all hands even if the machine thrusts them out of employ.

This is not a purpose novel, and the bringing in of machinery is only a minor part of the story, but lirs. Craik throughout the book shows that a master can be guided in all his dealings, both business and private, by Christian principles and thus be loved by his employees, respected by his associates, and adored by his family. Although the interest of the story lies in character development, the reader gets a clear picture of a typical middle class English family in the early nineteenth century.

William Westall draws a picture of the sad life of the weaver in his novel, The old Factory, written in 1881. Even though westall himself, had been a mill-owner before he entered the field of literature, he does not relate conditions as they were at the time in wich he lived but as they existed in the earliest stages of factory life. While he did not have any personal experience with the mill at the beginning of the century, his father had been a cotton spinner, and probably related his experiences to young william. The youth was so interested in his father's cotton--spinning business that he carried it on for quite a few years, and even after he becane a journalist, he showed his love for the factory not only in the novel just mentioned and by which he gained his first recognition, but also in another

${ }^{1}$ Craik, John Halifax, Gentlemen, p. 322 . 
novel which is mentioned in the next chapter. The setting is in Lancashire and he tells of the life in which he was reared.

This story centers around the Blackthornes and the Basels, manufacturers. It contrasts the methods used by the elder Blackthorne with those used by his son and by his associate, Basel. The former is fiery-tempered, haughty, determined; the latter are peace-loving and human in their dealings with the workers. The two families are joined also by stronger ties than those of business, for Blackthorne's son and daughter, marry Basel's daughter and son after bitter troubles which make Adam Blackthorne a kinder man to his employees.

He describes the cottagers, their lives, and their location, in these words:

It was a treeless country of stone walls, poor pastures, and rush-grown meadows. Desolate-looking farmhouses dotted the hillsides, and from time to time the travellers passed groups of gray and forlorn-seeming cottages, their broken windows stuffed with rags and pasted up with paper. White-faced women and sad-visaged children would occasionally appear at a door, held ajar to keep out the biting blast. In every one of these cottages was heard the clickity-clack, clickity-clack of the hand-loom; and gaunt and silent men went to and fro, bending beneath the weight of heavy loads of cotton warps and calico pieces.l

He has a character known as Yorkshire Joe tell the son of the mill-owner:
"They say as th' folks i' them there cot- tages is fair deeing $o^{\prime}$ cowd and hunger.... There isn't so very mony factories i' th' coun- try, though mony a one thinks as they're up $0^{\prime}$ th' increase. But that'll be no better for hand loom weyvers. It's just these steam looms as is ruinating on 'em. When they've plenty to do they cannot addle [earn] aboon fifteen or eighteen pence a day, and just now there's hundreds on 'em as isn' $t$ addling aboon two- pence-hapenny--work's that scarce. There

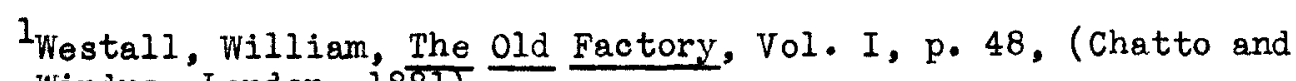
Windus, London, $18 \overline{81}$. 
is mony a one says as there'll be queer doings soon if there isn't a change. They wor sayin so only $t$ ' other neet at Th' Brown Cow. But it worn't allus so. I mind th' time when hand loom weyvers wor welly as weel off as quality--addling their sixty shillings and four pounds a fortneet and drinking two days a week at that . . Mony a one says it wor all along o' their prodigalness as steam loom coom up. suzhow [anyhow] they're ill enough off now and there'll be rough work afoor long; see if they willn't . . Why, brunning factories, breyking looms, and happen killing maysters, to be sure. They're terribly set on again, them as has started steam looms."1

Westall, in The old Factory, gives the opinions of two joint owners of a factory: old Adam Blackthorne, who was a slave-driver and therefore unpopular, wanted to silence rebellion by soldiers and gunplay; Mr. Basel, who was kind and reasoning, wanted to protect his life and property, but not by extreme measures. Westall has him state the belief:

"These poor devils of loom-breakers are ignorant, hungry, and ill-advised. As I understand they neither want to steal anything nor hurt anybody. They suffer, and, looking on machinery as the root of all evil, they seek to destroy it. In this they fail, and they ought to fail; but it would be a mistake to treat them as thieves and murderers. It is quite possible some of them may have to be shot, or bayoneted, or ridden down by dragoons, before the end comes; but, leave the responsibility to that of others, and let us try some less extreme remedy." 2

The author gives the opinion of the better class of workmen when

he has reter shuttleworth, a man for reform but against force, say:

"I am glad to think that our sufferings and our exertions have not been entirely in vain. There is a better spirit abroad than there used to be; the feeling of the upper class towards the lower is more kindly. Noble-hearted men are pleading our cause, and, bad as things are now, I am porsuaded that we are on the eve of better times. But--and that is why I am here this

1

Tiestall, the Old Factory, Vol. I, pp. 48-50.

$2^{2}$ Ibid., Vol. I, pp. 122-124. 
night--I never knew good done by violence. You will break this man's looms, you say. How will that benefit you? He will get more, and that without paying for 'em--the county will have to pay. Then some of you will be found out--for among so many there's sure to be traitors--and you'll get transported--happen hanged. Just think now. How can a few poor hand-loom weavers cope with a whole Government as can dispose of thousands of soldiers and constables, and millions upo' millions o' money? For all Governments are bound to protect property, and this Government of ours--and sorry I am to say it-sets more store on the property of the rich than on the lives of the poor; and when you attack Blackthorne's factory, you attack the King's Government. You are as sure to be licked, lads, as if you went with your banners and crowbars to fight a regiment of soldiers." 1

Westall shows how easily swayed a mob is, for the men who started to follow Peter away from the factory were quickly arrested and turned back to their measures of revolt by the mob leader who tells them:

"Tt's may be true what he says, that we cannot stop steam looms for good, but we can keep 'em back a bit tili the times mend and hand loom weavers can find summut el se to do. And if the country pays for new looms, nobody suffers and we benefit. They cannot make two or three hundred looms in five minutes. As to us being found out and persecuted. that's all nonsense, if we are all true to one another; and I'm sure we are. Give it up and go back? Not me!n2

Dearborn was a labor agitator, the forerunner of the sly, cunning delegates from the union we shall meat later. And Westall here gives us a glimpse of how these men went about leading the mob to acts of violence. But he had the men receive a surprise; as soon as they knocked in the gates, they were enveloped in a flood of light and saw troops with guns aimed at them. They were so dazzled by the light that they thought

1 Westall, The old Factory, Vol. I, pp. 140-14l. I Ibid., Vol. I, p. 143. 
there were many more soldiers around than were actually there. When the soldiers started to shoot and deluged them with water from a reservoir nearby, the workers quickly fled, and were so thoroughly frightened that they did not realize the ruse or that blank cartridges had been used. This was Westall's method of meeting the rioters.

There are two novels which particularly show Luddism with its grimness, its determination for vengeance, and its results. Both of these novels claim historical accuracy.

In the novel Through the Fray, G. A. Henty gives his interpretation of the Luddite riots. Henty is a jurenile novelist, and this book is written for boys. This author seems to pride himself on two things: first, historical accuracy, and secondly, training in character-building habits.

Through the Fray abounds in references to the history of the Luddites. In the preface of the book the author gives a short background of the history and then states:

In the present story I have endeavored to give you an idea of the state of things which prevailed in Yorkshire, where, among the croppers and others employed in the woolien manufactures, was one of the most formidable branches of the secret association. The incidents of the murder of $\mathrm{kr}$. Horsfall and the attack upon Nr. Cartwright's mill are strictly accurate in all their details.l

The story is laid during the years from 1807 to 1813 .

Henty, in this novel, strives to show his juvenile readers the tragedy of a hot temper and to show them that they can fight and conquer their tempers. Ned Sankey, the youthful hero, gets into trouble many times because of his fiery, uncurbed disposition.

IHenty, G. A., Through the Fray: A Tale of the Luddite Riots, preface,

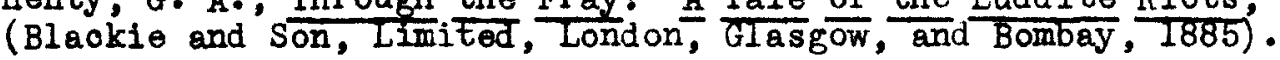


The culmination of his trials is his false accusation for the murder of his step-father, a mill-owner. Ned is acquitted for lack of evidence, but carries the stigma of a murderer for a long while before the guilty person is found. After his step-father's death, Ned takes charge of the mill, puts the new machinery into use, and brings forth the wrath of the Luddites. His mill is attacked, but he stands firmly on his principles, remains calm, and prevails over the mob. Henty compares the older weavers and croppers with the younger ones:

The older men suffered patiently and uncomplainingly, because they could not see any way to better conditions; they accepted the fact that high prices were due to the war, but did not know what the wars were for. 1

The young men had
a passionate desire to right their wrongs, to take vengeance on their oppressors. They were convinced that if they did but hold together and wreck the ma- chines, prosperity would return to Varley.
The organization for resistance was extensive. There were branches in every village in West Yorkshire, Lancashire, Nottingham, and Derby--all acting with a common purpose. The members were bound by terrible oaths upon joining the society to be true to its ob- jocts, to abstain on pain of death from any word which might betray its secrets, and to carry into execution its orders, even if these should involve the slaying of a near relation proved to have turned traitor to the so- ciety. 2

The society sent threatening letters to the manufacturers signed "King Lud" or "Captain Lud" such as the following warnings:

"Sir, this is to give you warning that if you uses the new machinery you are a dead man. You have

\footnotetext{
${ }^{1}$ Henty, Through the Fray, p. 49.

2 Ibid., p. 57 .
} 


\begin{abstract}
been a marked man for a long time for your tyrannical ways, but as long as you didn't get the new machinory we let you live, but we has come to the end of it now; the day as you turns on steam we burns your mill to the ground and shoots you, so now you knows it." 1
\end{abstract}

Henty points out that some manufacturers defied these warnings, fortified their mills, and held them. Others had their mills burned, and still others were murdered. But many of the more cowardly, dared not risk using the machinery, for they were constantly afraid, and the mills were often located in out-of-the-way places, along dark and lonely roads.2

Another thing Henty points out is that, as a rule, the workers employed with the new machinery did not object to it, for they were able to earn larger wages with less bodily toil than they could before the advent of machinery. But the hostility was with the workers who were thrown out of employment, who could no longer make a living by the looms which they worked in their own houses. 3

This novelist explains at length about a manufacturer's ability to get protection against the rioters. The capitalist need only to go before the magistrates, show them the threatening, letters, and ask for a company of infantry to guard the mill. They were then quartered in one of the mill-rooms, ready to keep the manufacturer and his mill from harm; other soldiers regularly patrolled the roads to the mills.4

The author has young Ned tell the magistrates, following an attack on his mills,

"I do not sympathize with the measures the men are taking to obtain redress for what they regard

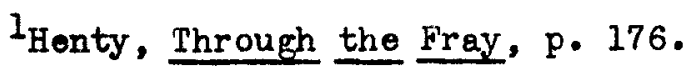

2 Ibid., p. 180.

3 Ibid., p. 196.

${ }^{4}$ Ibid., pp. 196-197-295. 
as a grievance, but I do sympathize very deeply with the amount of suffering which they are undergoing from the introduction of machinery and the high prices of provisions; and I am not surprised, that, desperate as they are, and ignorant as they are, they should be led astray by bad advice."1

The murderous methods of the rioters made many of the Luddites themselves, according to Henty, want to leave the society, but they feared to do so since they would be shot as traitors.2

Finaliy the author states:

The Luddite movement gradually died out. The high rewards offered for the discovery of the murderers of Mr. Horsfall and of the assailants of Cartwright's mill had their effect. Three croppers, liellor, Thorpe, and Smith were denounced and brought to trial. All three had been concerned in the murder, together with Walker, who turned King's evidence for the reward--Meli or and Thorpe having fired the fatal shots. The same men had been the leaders in the attack on Cartwright's mill.

They were tried at the assizes at York on the 2nd of January 1813, with sixty-four of their comrades, before Baron Thomas and Judge Le Blanc, and were found guilty, al though they were defended by Henry (afterward Lord) Brougham. Fourteen of the others were hung, as were five Luddites who were tried before another tribunal.

After this wholesale act of severity the Luddite disturbances soon came to an end. The non-success which had attended their efforts, and the execution of all their leaders, thoroughly cowed the rioters, and their ranks were speedily thinned by the number of hands who found employment in the rapidly-inoreasing mills in the district. Anyhow, from that time the luddite conspiracy ceased to be formidable.3

In 1893, Mrs. G. Linnaeus Banks wrote a novel entitled Bond Slaves: the Story of a Struggle, which she calls a "romance of history"4, and

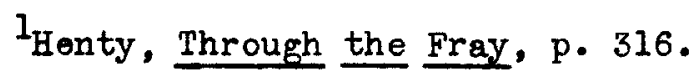

Ibid., p. 329 .

3 Ibid., p. 382 .

${ }^{4}$ Banks, Mrs. G. Linnaeus (Isabelle), Bond Slaves: the Story of a Struggle, p. 3 of preface, (Griffith Farran and Co., Newberry House, London, 1893). 
which uses the historical Luddite leaders mentioned at the close of Henty's book, as a basis for her novel. Mrs. Banks is careful, detailed, and accurate in her accounts, and deals with real people, events, and places. She lived in Manchester, had visited and resided in Yorkshire, and was well acquainted with the type of people she describes. In her preface to Bond slaves she shows how well equipped she was for the task. Not only had she heard fireside tales of the Luddite rioting, but she studied old processes of manufacture, ransacked old book-dealers' catalogues, bought and borrowed rare books on the subject. Concerning the mass of historical facts used throughout the novel, the author writes:

I am doubtful whether the ordinary reader will thank me for overloading my thread of fiction with so many beads of indubitable history.1

This novel is the depressing but graphic story of Walter Hartland's degeneration as a result of the influence of George liellor and the Luddite society on his life. She pictures lellor, the Luddite leader, as headstrong and reckless, the first in danger and the last out of it. He drew Hartland into the society before the latter realized it, and saw that Hartland was always in the front ranks. The book shows the sorrow that resulted for all in the Hartland family.

Nirs. Banks states that her novel

tells of the lava flood that seethes in the brain and maddens in the veins of men long-suffering themselves, or passionately indignant over the wrongs and injustices, real or imaginary, heaped upon themselves or others. And it must be remembered that few questions are single-sided; the masters had their feelings and their grievances co-existent with those of the unemployed or the workers under paid.2

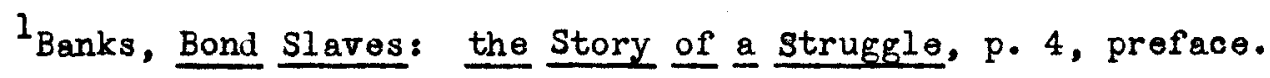

2 Ibid., pp. 119-120. 
Mrs. Banks lays much of the blame on Robert Owen, the philanthropic mill-owner, for she says that, although he tried to do good by writing essays showing ideas of social reform, he really did mischief since the motto of "Liberty, Equality, Fraternity" promulgated in the essays aroused the half-educated, undisciplined men who read his essays, and among whom was this future Luddite leader, George Nellor.l

The novelist gives the horrible oath the Luddites took:

"I,
do deciare and solemnly swear that I will never re-
veal to any person or persons under the canopy of
heaven the names of the persons who comprise this
secret committee, their prooeedings, meetings, places
of abode, dress, features, complexion, or anything
el se that might lead to a discovery of the same, either
by word, deed, or sign, under the penalty of being sent
out of the world by the first brother who shall meet
me, and my name and my character blotted out of exis-
tence, and never to be remembered but with contempt
and abhorrence. And I further do swear that I will
use my best endeavours to punish by death any traitor
or traitors, should any rise up among us, wherever I
can find him or them, and though he should fly to the
verge of nature I will pursue him with unceasing ven-
geance. So help me God, and bless me, and keep my
oath inviolate." 2 .

Such an oath, given by dimmed lantern, late at night, in the heart of the woods, and with masked, grim faces surrounding the new member, the author states, could not be voluntary, since the oath-taker had no idea of the tenor of the oath. But when the oath was taken, the member could not draw back, for at each meeting a roll call was taken, and too many black marks against a name for absence, meant death for that person.

Lrs. Banks describes a gruesome club meeting of the Luddites. One shaded oil lamp on a table at the end of the room cast the room into shadow, and in the front of the room were horrible symbols that struck terror into all hearts, and especially so to men who were as uneducated

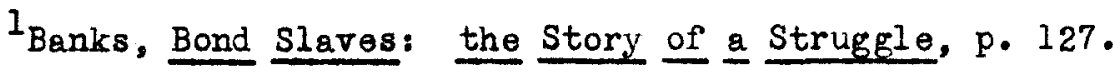
Ibid., p. 166 .
} 
and as superstitious as these hand-loom qperatives.

At the extreme end of the apartment, at an elevation behind the presidential chair, was a large black screen, upheld by two silent figures in black masks, clothed in the white garments of the grave, and holding murderous-looking daggers in their hands.

This black screen was a transparency, with a brilliant light behind, which falling sideways on the grim upholders, made them visible in all their ghastly suggestiveness, of which the awful transparency left not a doubt. There, strongly depicted in white on the black ground, was a full-sized coffin with a nameless 1id, and above that a grinning skull and crossbones, set betweon a pistol and a dagger. And arching over all, to make the import sure, was the inscription, "Death To The Traitors."I

The novelist describes the attacks on the mills by men with blackened faces, who wore smockfrocks or skirts over their clothes, who were well-armed and had been drilled in the use of arms, and who carried also hatchets, hammers, and staves with which to break up the machinery. Their cry was "General Ludd and his men--open, or we break in the door."2 She states that for a long time the Ludaite movement had many sympathizers and received money from all over the country to carry on their work. But she points out that Luddism was a machine that needed plenty to keep it going, and when the mob began to raid private homes and demanded arms, the people began to garrison their houses, requested militia to protect them, and became alarmed at the vengeance of Luddism. Robbery and assassination became a new phase of the movement. She cites one instance where the mob in

exasperation sacked the cottages and houses of the workmen who had served their good masters in defence the previous day. Women and children might shriek, but mob was master, or thought so. Into one huge bonfire went the furniture and effeots alike of clerks and weavers, and finally they gave

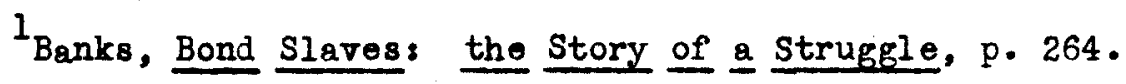

2 Ibid., p. 216. 
to the flames the abandoned mansion of the chief partner, with all its valuable contents, trampling down gardens and ornamental grounds into a hideous waste. The contest ended in the arrival of troops, more bloodshed, a number of prisoners, and the deaths of two more onlookers from stray shots.1

Finally, according to the author, so many arrests were made, and so many of the leaders were either hung or sent out of the country that Luddism in Yorkshire was ended.

Mrs. Banks closes with the statement:

There were other Luddite legacies of which no record has been preserved,--legacies of shame, disgrace, poverty, which clung to the kith and kin of the miserable convicts like a leprosy, until time brought healing; but the Bond Slaves of the fearful oath were never free from its obligation or its dread penalties whilst they walked the earth. The grave closed over them and their evil secrets. That is well kept which no man dare reveal.2

In all of these books the novelists stress that fact that rioting and struggling against invention arailed naught, for, as Stephen Royd is made to say in Mistress Barbara,

Machinery will remain, and none knows yet how near the world will come to a second Golden Age - . We shall see the combing-machine and the power-loom perfected, as well as the spinning frame. We shall manufacture cloth with fifty times the speed, and a fiftieth of the labour that it costs to-day. Lien will have leisure to live, after their short day's work is done."3

Therefore, these novelists show that while they feel the futility of workers combating machinery, they also feel that the workers can be held at bay by determined, but cool measures of reasoning on the part of the masters, and believe force should be used only as a last resort.

1 Banks, Bond Slaves: the Story of a Struggle, pp. 284-285. 2 Ibid., p. 412 .

${ }^{3}$ Sutcliffe, Halliwell, Mistress Barbara, p. 147, (T. Y. Crowell and Company, Now York, 1901). 
For, as Westall adds at the end of the first volume of his book

if they drive weaving out of one district, it will

only take root in another; and even if they were to succeed in destroying every power loom in England, they would simply benefit foreign nations, to their owm loss, and the loss of the country. 1

This writer seems to feel that the best solution possible is found in the words of Peter the workman:

"Better join with others and try to get Parliament reformed and bad laws repealed; for if the laws were just and the law-makers honest, there would be work and porridge for us al1." "2

In Shirley, Miss Brontë emphasizes the fact that the mill-owner, Noore, did not gloat about his victory over the workmen, but instead became more gracious, and more prudent. She has him say to the young woman he marries:

"I have seen the necessity of doing good: I have learned the downright folly of being selfish." 3

Miss Bronté has him decide to give work and food to the starving and unemployed who will come to the mill for help, start day-schools and Sunday-schools, and treat all the workers once a quarter.

Henty has the mill-owner, Ned Sankey, aid the poverty-stricken hand-loom operatives by giving them work to do in their cottages. The author states that Ned knew he would lose money by this policy, and that he could not continue such a transaction indefinitely, but felt he could tide the weavers and the croppers over their present difficulty, and help them adjust themselves to the new machinery. Both the historian and the novelist, then, show that it was useless for the workmen to fight the advent of machinery, that civiliza-

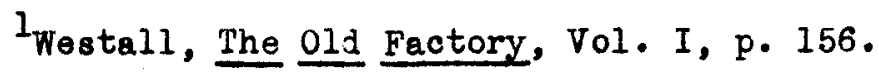

2 Ibid., Vol. I, p. 142.

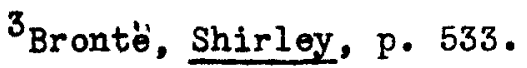


tion made modern methods necessary, but the novelists felt that a sympathetic attitude on the master's side would help the workmen over the difficulty, and an interest on the workmen's part in Parliamentary reform would in some manner help the down-trodden. Since none of these novels were written at the time of greatest stress and agitation over new methods, they are not purpose novels in the same sense as are some of the factory novels discussed in the next chapters. But they do give the student an insight into this first period in the history of the factory system, and were written at a time when labor development was being studied, and English literature reflected this interest. These novelists showed the middle class that the laborer's grievance started early in the century, that he was illtreated, but that when the linglish people did not try to help him, he took the matter into his own hands, with tragic results. The English people could learn better how to deal with the situation in the latter part of the century by studying the struggles of labor in the beginning of the century. 
CHAPTER II

The Problem of the Exploitation of Women and Children 


\section{CHAPTER II}

The Problem of the Exploitation of Women and Children

The problem of the factory women and children during the first part of the nineteenth century is the saddest and the most deplorable phase of factory development. It demanded reform since both the bodies and spirits of the women and children were crushed by the factory regime.

The progress of the factory system demanded a mass of workers to watch the machinery, to place in the cotton, to take out the thread, to bind together broken ends; these mechanical duties demanded little strength or intelligence, and since women and children not only could do this work satisfactorily, but also could be hired for a much lower wage than men, their labor was used wherever possible. Then, too, their size and stature enabled them to get under machines and in corners where men could not go.

The hours were long in the early part of the century; even the youngest children worked from twelve to fourteen hours daily. The mills began work so early in the morning that it was usually necessary to eat breakfast at the mill. Since the machinery was not stopped for breakfast, food was quickly grabbed with a free hand when occasion allowed. At noon, a period from a half-hour to an hour was allowed for the meal. Since there was a growing demand for cotton goods, since factories could now be lit with gas, and since artificial power made the labor less severe, the millowmers kept the factories running as long as was possible. Outside of Sundays, there were few holidajs during the year, hence the strain of the long hours was almost unbearable.

Other factory evils attracted attention to the women and children laborers. The moving machinery caused many accidents, especially to the tired children. The high temperature, poor ventilation, and uncleanliness 
kept them from being healthy; and since they had no method of united action, they were at the mercy of the masters.

One historianl points out that there were three arguments for a change in conditions for these sufferers. First, there was the sentimental argument; that is, that in such a wealthy, humane, Christian country as England, it was unendurable that women and children should be subjected to such hardships. Secondly, there was the argument that demoralizing effects resulted from children having no intellectual and moral training, little home influence, and every opportunity for learning ignorance and vice. The third argument was based on the physical degeneracy of these operatives. It pointed to the stunted growth, the enlarged joints and swollen limbs caused from standing long hours and walking to and fro, day after day, in early life.

This historian shows that the capitalists opposed those arguments. First, they said that these opponents should remember how much the factory helped the employment situation, since many thousands would have no livelihood were it not for the factories. Secondly, they pointed out that if the hours were shortened and work made less exacting, the output would be greatly decreased, and England would lose her supremacy in manufactures. Thirdly, they argued that laws restricting hours would interfere with freedom of labor, of capital, and of contract; if those concerned, the employer and the employee, were satisfied with the hours and the conditions of their labor, why should the government interfere? This was the "laissez-faire" argument that held sway during the first half of the century, and was responsible for the difficulty in accomplishing legislation for the women and children of the factories.

${ }^{1}$ Cheyney, Edward P., An Introduction to the Industrial and Social History of England, $\overline{\mathrm{pp}}$. 251-254. 
Some of the masters felt, however, that work could be made more endurable; and it was largely owing to such mill-owners as Robert Owen, who, with his model mill village, proved that business would continue even though hours were shortened and improvements made, that interest in the factory legislative movement was kept alive.

All the factory acts from 1802 to 1847 dealt with betterment of the conditions of the women and children, especially of the latter. In 1802 an act was passed which attempted to better the conditions of the pauper apprentices. History records the tragic condition of these orphan or unwanted children sent by parishes, even from such large towns as London, to Lancashire to be worked in the mills; thus the parishes were relieved of the task of providing for them, and the manufacturers obtained plenty of cheap labor. Under this act the hours were shortened to twelve (exclusive of meals), night work was forbidden, a little education was to be given, and better ventilation was to be provided. Although inspection was necessary, it was not properly enforced, and the act was ineffective. However, the principle of limiting hours by legislation had been established, and the evils of apprenticeship to some degree disappeared.

In 1819 an act had been passed stating that no children under nire were to work, and limiting the time of work for children to twelve hours daily, exclusive of meal time; in 1825 another bill was passed making a twelve-hour day for all under sixteen years of age, with only nine hours on Saturday.

In 1831 an act was passed making a twelve-hour day for all under eighteen, with no night work for any under twenty-one. But the act of 1833 was the most important up to this time. By this act the children from nine to thirteen had a forty-eight hour week, young persons from thirteen to eighteen, a sixty-nine hour week with no employment during 
the hours from 8:30 P.M. to 5:30 A.M. and, best of all, the first government inspectors were appointed. Before this time the justices of the peace or the local clergy had inspected the mills, but this system was ineffective because these local people usually did not want to make themselves unpopular with their neighbors, the manufacturers, who held a great part of the money of the comunity. The government appointed inspectors, although only four in number to enforce the law.

Because there was so much difficulty in carrying out the law of 1833, another in 1844 was passed that extended the same protection to women as to young persons, the hours to be checked by a public clock, the day to begin whenever any woman or child began work, and mealtimes to be simultaneous. By this act dangerous machinery was to be enclosed, accidents were to be reported, and employers were to be held personally responsible for unsafe conditions in their factories.

The law of 1844 had thus established the primary legislative features of the British system. The main foundations had been laid. The obvious accompanying step was the strengthening of the adninistration to bring effective and more nearly uniform enforcement.1

But the act that was the most important in lifting the great burden of mistreatment from the women and children was that passed in 1847 having only a ten-hour day for all women and children workers, with halftime on Saturdays. In 1850 a law was passed allowing the mill to operate between the hours of $6 \mathrm{A.M}$. and $6 \mathrm{P.M}$. This really lifted the burden off the women and children, since the manufacturer could not evade the law as easily as he could with no limitation on the hours the mill could remain open.

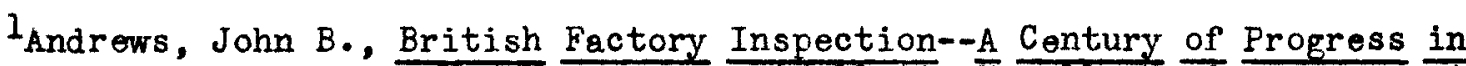
Administration of Labor Laws, $\mathrm{p} .5$, (Bulletin No. 11, U. S. Government Printing office, 1937). 
These factory acts show that the English people were awakening to the need for reform to relieve the women and children toiling in the mills. Some novelists also showed their awareness for the necessity of lightening the labor in the factory. These authors are: Frances Milton Trollope in The Life and Adventures of Michael Armstrong, the Factory Boy (1840), Charlotte E'lizabeth Tonna in Hel en Fleetwood (1841), William Westall in Birch Dene (1889), and Halliwell Sutcliffe in Mistress Barbara (1901). These writers showed that the women and children working in the mills were physically, morally, and spiritually mistreated and it is the purpose of this chapter to check these novels for historical accuracy.

Since the treatment of the children was even worse than that of the women, and since the plight of the pauper apprentice was considered first by legislature, this discussion will, therefore, center first on the pauper apprentice, then turn to the factory child in general: his parents' attitude toward his working, his accidents from the machinery, his mistreatment by his superiors, his ill-health, his low morals, his lack of education, and his inability to get redress for his mistreatment. Lastly, the plight of the factory women will be investigated. Westall and Sutcliffe wrote their novels in 1889 and 1901 respectively, but, since they deal with the period between 1815 and 1825 while Mrs. Trollope and Mrs. Tonna are interested in the period around 1840, the novels written by the men will be examined before those written by the women. Westall, Sutcliffe, and Mrs. Trollope deal primarily with the conditions of the pauper apprentice.

It was nothing new for the children to work, but it was only with the advent of machinery and factories that they were so enslaved. Before that, they had worked at home with the rest of the family under parental care. While some parents may have been cruel and abusive, 
they were the exception. But now, with the unceasing work of the machine, and with the pitiless overlooker who cared only for the work to be done, the scene changed, and the child, especially the pauper apprentice, suffered.

Westall, about whom mention was made in the preceding chapter, was interested in the pauper apprentice. He wrote the novel Birch Dene in 1889, about life in Lancashire during the years from 1815 to 1820. This book was not written to arouse the interest of the reading public in conditions existing at the end of the nineteenth century, but it was written to show the people the tragedies of one of the earlier stages of factory life. Inasmuch as in Birch Dene a former mill-owner is writing, the reader gets an insight into how disgusted a kindly, sympathetic manufacturer could be with the littleness of such employers as the kuberry brothers in Birch Dene.

This novel relates the story of Robin, youth whose mother had died as the result of humiliation over her trial in court for attempting to steal a coat with which to shield her shivering child from the cold. The father, an army officer, had failed to return to London. The boy, frightened and lonely, was stricken with brain fever. When he finally grew better, he found he could not remember the past years of his life. An old book dealer had become interested in the child, took him home, reared and educated him, and left him an inheritance. But a nephew of the old man contrived to get the money and to send Robin to Birch Dene as a pauper apprentice to work for the Ruberry brothers. Robin's superior intelligence won him friends, not only of the laborers, but of the mill-owners, and the young heiress, Hiriam Ruberry. Robin finally married Miriam after he found that he was the son of kindly Miajor Dene, a landed gentleman. Robin received the inheritance not only of his father, but also of the old book-dealer. 
He became a partner in the Ruberry firm and tried to make life happier for the pauper apprentices.

Westall shows the horrors of the apprentice life through the experiences of this superior apprentice. He shows first Robin's introduction to the apprentice house, where an illiterate and untidy elderly couple keep a ramshackle home for the children. He pictures the bare furnishings of the place and the supper of porridge, a little blue milk, and a chunk of coarse bread. He shows how disgusted the new arrivals are at their surroundings and their poor fare, and he shows the neglect of these waifs. They are truly property children or little white slaves.

Westall describes, vividly, the children who had been apprenticed to the factory awhile.

Nost of the boys had nothing on but trousers, shining with grease, and coarse, blue shirts, open at the neck. Their hair was tangled, unkempt, and powdered with cotton fluff; several had black eyes, others ugly wounds on their hands and fingers bound with blood-stained rags. The girls, like the boys, were bare-footed and bare-headed. Their hair was pinned up, very few wore either bodice or gown, only a single under petticoat, and over that a "bishop" or "brat" (a long apron reaching from the neck to the heels). Compared with this lean, sallow, half-naked crew, redolent of factory grease, the newly arrived Londoners looked like so many ladies and gentlemen.l

Then Westall describes the utter confusion that reigned after supper, how the children swore, tore each otiner's hair and punched one another, until the head of the apprentice house stopped the din by cracking at the children with a horsewhip and sent them off to bed. He describes in detail the gloomy, bare, uninviting garret sleeping room with the beds arranged in a double tier all around the room like the bunks on

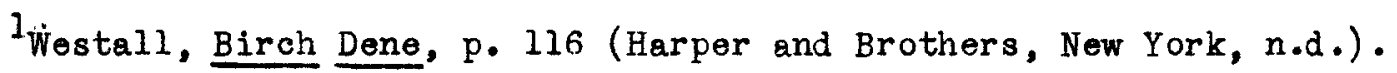


a ship.

The apprentices, with grim humour, dubbed them coffins--probably because many of their occupants had been taken thence to their long home.l

He continues to describe the master of the house as he flourished his whip while the children were undressing so that they hurriedly jumped into their filthy and ill-smelling beds, after which he double-locked the door. Since the windows were barred, the little apprentices were virtually prisoners. Westall shows that it was useless, however, to fear that the children would run away, for they had neither clothes nor money to get far without attracting attention, and if they did attempt to escape they were soon found, returned, and brutally punished; often they were tied up by their hands and flogged until they fainted.

The author then describes how the smaller children picked up loose cotton and swept the floors while the older boys and girls dexterously pieced up the broken threads.

To and fro these children walked all day long, from six in the morning, till half-past seven at night, with an interval of only an hour and a half for rest and meals--often even longer; for, though the legal limit of the day's work was twelve hours, there were no inspectors to enforce the law, and, by early starting and late stopping, many employers lengthened the stint to thirteen hours. How heavily their severe labor told on the children was show by their looks. Their faces were haggard, their forms stunted, their movements languid. Wany did not long survive the terrible ordeal which they were compelled to undergo, and most of those who lived were broken in constitution before they reached middle age.2

Westall then tells how by evening the factory smell and the oppres-

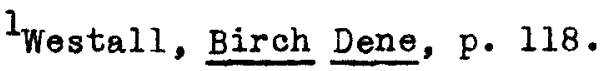

2 Ibid., p. 129 . 
sive heat were so unbearable that the girls often fainted, the little ones were almost too weary to stand, and the overseers hurled oaths, threats, and missiles at the children, and cuffed and strapped their tired little bodies. He points out, therefore, that when the engine finally ceased and the day's work came to a close, the apprentices,

shoeless and half-naked, picked their way, shivering, through the cindered yard to their wretched quarters. But a bright fire and hot porridge awaited them, and after thirteen hours in the suffocating spinning-room, with its jarring noises and monotonous toil, the apprentice house was a haven of rest and a place of delight.1

The historian Lincoln, in his book on the factory, describes the life of the pauper apprentice by saying:

Besides the factories stood apprentice houses in which the children were lodged and fod; and it was the custom for the manufacturer to furnish the apprentice with clothes. The work required of the children was exacting. The pay of the overseers was fixed in proportion to the work produced, a circumstance which bore hard on the apprentices. The greatest cruelties were practiced to spur the children to excessive labor; they were flogged, fettered, and in many cases they were starved and some were drivon to commit suicide. We have it on the authority of John Fielding himself, a master manufacturer and member of Parliament for Oldham, that the happiest moments in the lives of these children were those passed in the workhouse.2

Although westall shows the factory conditions by picturing Robin in the apprentice house and in the factory, it is only for the purpose of showing, in the background, the great mass of underfed, underprivileged, tortured children for whom Parliament and the humanitarians tried to enlist the cooperation of the public during the first half of the century. Another way in which Westall discusses the situation is to make one

\footnotetext{
I'Westall, Birch Dene, p. 134 .

${ }^{2}$ Lincoln, Jonathan Thayer, The Factory, pp. 76-77, (Houghton Mifflin Company, Boston and New York, TI2).
} 
of the landed gentry, a man known in the novel as Najor Dene, evidence his interest in and concern over these children and do all in his power to help them; he also uses a young lady, Niriam, the daughter of one of the mill-owners, to soften the hearts of the Ruberry brothers. This method would show the readers that they also can be liajor Denes and Miriams in their age to help the conditions of the working people. The emphasis the author places on the many, many factory children suffering untold wrong and their inability to cope with the situation, makes the reader feel the children's dependence on him.

At the beginning of the century Haliwell Sutcliffe wrote histress Barbara to show the plight of the factory child in 1825. Sutcliffe was reared in Yorkshire, loved the moorlands and their people. Nany of his novels have Yorkshire as a background, and depict the life of the English landed gentry. The novel Mistress Barbara paints a sympathetic, vivid picture of Squire Cunliffe, a landed gentleman in straightened circumstances, and his lovely daughter Barbara. Stephen Royd, the mill-owner, himself descends from a long line of landed gentlemen, but has been reduced to trade through necessity, and is sensitive to the view his own class held of trade. His whole effort is to earn enough in business to be able to regain his family's property, and thus be in a position to marry Barbara. This he accomplishes after many struggles.

The book deals with the hard times of 1825 and shows the difference between the dealings of the philanthropic though shrewd capitalist, Royd, and the hard, grasping manufacturer, Booth. The author voices his protests of the age through the thoughts and conversations of the characters Stephen Royd and Parson Horrocks.

Sutcliffe has the Parson tell Stephen: 
"There are middlemen in this as in other trades, and the brute who needs labour buys from him who gets his children by the scores from workhouses. Millmasters, workhouse-masters, middlemen--they all play for their own hand."I

The novelist gives an interesting picture of these pauper apprentices. Royd is watching them file out of the factory for lunch.

He saw the out-coming line of children pass in by the low doors of the hovels where they ate, and slept; a little time sufficed them to swallow with famished haste, such food as was provided; and then they came out again, and stood about in listless groups. Not one of them made any attempt to play; the ears of all were turned toward the great bell that would by and by be summoning them to toil. still watching, Royd saw that two or three of them-children whose faces held still a fragment of intelligence-were sliding off toward the row of pig sties that lined one wall of the yard. He followed them, and the listless groups shrank feebly from him, with the instinct of wild animals, as he pushed his way between their ranks. As he neared the railings of the sties, he saw the adventurous three climb over, and mingle with the pigs, and fight with them for the meatballs that had just been thrown to them. For Ephraim Booth was careful of his pigs, and fed them well, knowing that what he spent would come to him again with increase.

Like one in a night-mare, Royd stood and watched the grim contest of the human with the brute. He had heard much of this mill-life; he had thought to have plumbed in fancy its lowest depths; but what he saw here was unbelievable; if one had told him of it-was scarcely credible even now as it passed before his eyes.

The pigs were well-used to the invasion, so it seemed; they had fifty ruses for securing their food, and the children tried to match their guile with the greater guile. The overlooker--inevitable as the air they breathed--stepped in to shorten the impromptu meal. The lash came down, and the children scurried fast as they could climb across the fence; and the pigs were assured once more of a full meal.2

One historian writes about the poor food:

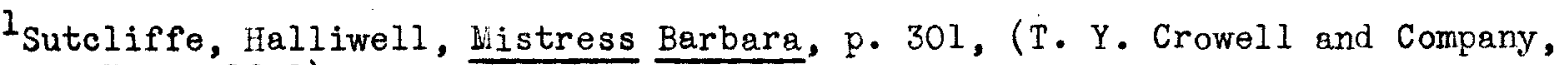
New York, 1901).

2 Ibid., p. 337 .
} 
The scantiest share of coarsest food capable of sustaining animal life has been doled out to the parish apprentices; in the bothies and outhouses of cotton factories, boys and girls, suffering from the unsatisfied cravings of hunger, have watched for the swineherd, have stealthily struggled with pigs for food, and have been fed upon the purloined contents of the pig-trough.l

Another writer interested in the apprentice child was Frances Milton Trollope. She wrote her novel on the Life and Adventures of Michael Armstrong, A Factory Boy. This was the first novel on factory life. It was written according to the biographer of Nrs. Trollope's son Anthony ${ }^{2}$, in 1839 , was published at first serially, and was so popular that the following year it was printed in book form. This biographer states that the novel was based on notes taken by the authoress and her son when they visited Lancashire and Yorkshire. Since they carried letters of introduction from Lord Shaftesbury, they were shown as much of mill life in remote moorland valleys as time allowed.

This biographer continues:

From the side of the enemy, the book was paid the compliment of a counter-issue from the factory owners' point of view. In August 1839 (about five months after Michael Armstrong had begun to appear) there was published the first ten monthly numbers of Mary Ashley, or Facts upon Factories (there is surely an aggressive purpose in the heroine's name), a work by "Frederic Montagu," all advertisements of which were headed with the legend "Mrs. Trollope refuted!"3

Mrs. Trollope tried to be truthful, but she was relating an unusual apprentice situation in an out-of-the-way moorland situation.

I"Alfred" (Samuel Kydde), The History of the Factory Movement, 1802-1847, Vol. I, p. 22, (Simpkins, Marshall and Company, London, 1857).

${ }^{2}$ Sadleir, Michael, Anthony Trollope, p. 93, (Houghton Mifflin Company, Boston and New York, 1927).

3 Ibid., p. 94 . 
In the preface to Michael Armstrong, the novelist has a statement of her purpose for writing the novel. This purpose was to

show the hideous mass of injustice and suffering to which thousands of infant labourers are subjected, who toil in our monster spinning mills . . . The true but most painful picture has been draw faithfully and conscientiously. Of course voices have been raised to deny loudly the truth of all the author's statements, and to assert the whole to be a mere tissue of invention and falsehood. The same charges have been made against her upon another occasion, and she has lived to see the truth of her statements, so impugned, universally admitted. She awaits with perfect confidence the time when similar justice shall be rendered to these pages.. . The author is well aware that many, as well operatives as their superiors, who were engaged in a virtuous struggle against the lawless power which oppresses them, deplore the madness of these ill-advised men as much as herself. . No misconstruction of principles, no misconception of motives can exist with regard to an attempt to ameliorate the lot of the infant labourers.1

Nrs. Trollope's description of the mill which was hidden from public eye and ear, abounds in pictures of horror and servitude. She paints the little apprentices as little savages, poorly fed, poorly housed, poorly treated. She gives a vivid picture of a fever epidemic in the mill, and tells how the children, both the sick and the well ones, were kept together until those with the fever could no longer stand at their work, and then they were thrown in a bare room and left to live or die. She says that the overlooker

went on cleverly supplying the missing hands by recommending to the manager that one healthy child do the work of two, and cleverly also getting all that died by day buried at night without making any fuss or fidget whaterer.2

The historian "Alfred" writes concerning the hasty burial of

$1_{\text {Trollope, Frances Milton, hichael Armstrong, preface, (Dodd and Miead }}$ Company, liew York, n.d.).

${ }^{2}$ Ibid., chapter 20 . 
the pauper apprentices:

Many having died in the night, their bodies were stealthily removed, and were buried without ceremony in graves unknown to their former comrades--these bodies were cast into the earth and buried with the "burial of an ass."

Mirs. Trollope not only shows the conditions of the pauper apprentice in her book, but she also shows the conditions of the factory child in general. Kichael Armstrong is the story of a poor factory boy's rise despite the efforts of Sir Matthew Dowling, a newly-rich, hard-hearted, unprincipled manufacturer, to enslave all the factory children. The author wants to show that working in a factory does not necessarily make a person unfit to associate with his fellow-beings. To show this, she makes an heiress, hiss Brotherton, bocome interested in several factory children, adopt them, and some years later marry one of them. The capitalist receives his recompense, loses his money, and dies a horrible death.

Just as Westall in his novel showed some beneficent characters who tried to understand and remedy the terrible conditions, so also Mrs. Trollope shows a rich heiress, Mary Brotherton, who is kind and intelligent and eager to find out about conditions in existence in the factories at this time. Mrs. Trollope causes her to visit a preacher, a Dr. Bell, who had been for a long time interested in the lot of factory people, but helplessly looked on, since he was not able financially to do much. But the author uses Dr. Bell to explain conditions not only to this interested and inquiring heiress, but also to the reader. The factory child at that time was a property child; it was strapped and docked onefourth of a day's wage if it were only one minute late to work. Mothers and fathers would prod and carry sick and fainting children to the

I"Alfred," (Samuel Kydde) The History of the Factory Movement, Vol. I, p. 24. 
factory to escape a double fine. Children were hired in place of their parents because they worked for less wages than adults; usually the child's wage, according to lurs. Trollope, was six shillings or a little more a month, depending upon the child's age and physical ability, and, since fathers hated to be idle and to see their weary children come home from work, the gin-shops proved to be a good place for them to forget the wrongs of the factory system. The author has Miss Brotherton visit homes and factories, and the reader sees through her eyes the conditions ars. Trollope must have met when she personally toured the factory district before writing the book.

Sutcliffe describes the mill of the money-loving capitalist Booth as a place where

the lamps flare garishly, and the spindles never
rest, and men make night into day for the little
bairns that have scarce grown to lisp their prayers. I He points out that they work until they have no strength left to take them home, and relates the tragic experience Royd and the Parson encountered when they met a little seven year old girl walking, or tottering, home almost asleep on her feet. The child had been working from five in the morning until late at night, was undernourished, and had been beaten at the mill by the overlooker for sleeping at her work. She expected no kindness from anyone. Her response, whenever she was roused from her stupor was,

"Is 't time to waken, father? Father 'tis cowd and dark--let me lig a wee while longer."2

for she always thought she was being awakened to start again to work.

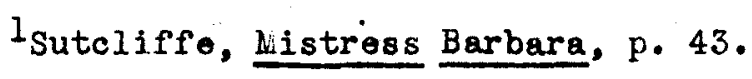

2 Ibid., p. 48 . 
This child soon died from the strain put on her frail little body. As to the attitude of parents toward child labor, Sutcliffe has this little girls's mother say,

"He has us which way we turn, has Ephraim Booth. We said our childer shouldn't work for him; we framed a union among ourselves--that war i' th' better days-an' there war nawther chick nor child i' Marshcotes went to th' miln. An' what did he say to that Parson? We thowt it'd learn him to mend his ways, or boggar him--an' i'stead he goes to th' Heathloy Workhouse, an' gets a score o' pauper childer, an' now, we're forced once an' again to send our childer to him, he pays 'em less no wer."l

One historian explains about the factory children.

As the population of the manufacturing centres of the North multiplied, the demand for little London paupers fell off. The workmen were driven by poverty or greed to send their own children to work in the factories, and thus, in the long run, to beat down their own wages, by the competition of their own children. Wany of them hated the necessity, and some saw that they were really injuring their own class. But what could a man do but imitate his neighbors? His own wages were, perhaps, a shilling a day. His halfdozen children could add fifty per cent to this; and it was almost impossible to feed them otherwise.2

A fourth novelist, known as "Charlotte Elizabeth" wrote Helen Fleetwood in 1841 to arouse interest in the factory child and factory woman. This writer, Mrs. Charlotte Elizabeth Tonna, was as interested in religious creed as in factory conditions; she was very hostile to the church of Rome. While her religious feeling is present throughout the book, it is the factory about which krs. Tonna speaks most. of her book, she herself says,

Let no one suppose we are going to write fiction, or to conjure up phantoms of a heated imagination, to aid the cause which we avowedly embrace. Names may be altered, characters may be grouped, with some latitude of license; but not an incident shall

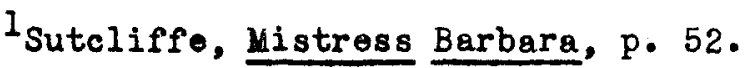

2 Traill, H. D. Social England, Vol. VI, p. 217.
} 
be coined to serve the purpose, however good,
so far as relates to the main subject--that is,
to the factories of this, our free and happy
England. Vivid indeed, and fertile in devices
must the fancy be that could invent a horror be-
yond the bare, every-day reality of the thing!
Nay, we will set forth nothing but what has been
stated on oath, corroborated on oath, and on oath
confirmed beyord the possibility of an evasive
question. Neither will we lift the veil that
piety and modesty would draw over the hidden
atrocities of this diabolical child-market. Elas-
phemy and indecency may, and do abound, turning
every mill into pandemonium; but it is not need-
ful to sully our pages with either. . Let the
pestilence preserve the cloud of darkness in which
it walks; we only desire to show the withered re-
mains of its poor blighted victims.

This statement alone shows something of the author's method of writing; the book is a sentimental, pathetic picture of the people, but the author tries sincerely to show the struggles of the factory women and children.

Helen Fleetwood centers around the heroine, Helen, and the family who adopted her, the Greens. Hard times compel them to leave their country home and go to the city to work in the factory. Their life here is related in a minute manner. Helen is persecuted by her coworkers becsuse she tries to live a Christ-like life. She finally dies partly as a result of suffering from the taunts hurled at her, and partly from the disease contracted in the hot, ill-ventilated factory room. The rest of the family go back to the country, the Widow Green preferring Iife in a poorhouse to that in a heartless, manufacturing city .

Just as Westall showed the contrast of life in a London bookshop under a kindly proprietor with life as an apprentice under an

I Tonna, Charlotte Elizabeth, Helen Fleetwood, Vol. I, p. 59, in Works of "Charlotte Elizabeth," 3 vols., (E. B. Dutton and Company, New York, 1845). 
unsympathetic mill-owner, and just as $\mathrm{Mrs}$. Trollope contrasted life in the worker's home with that of the mill-owner and wealthy class, so Mrs. Tonna contrasts life in the country with life in the manufacturing district. Then she shows how the parents in rural districts were often deceived by parish authorities into believing that the factory district offered untold opportunities to the persevering. In Helen Fleetwood one such shrewd man described it as a place where there is

good lodging, capital clothing, the best to eat, and plenty of it, kind neighbors, generous masters, skilled doctors, fine preachers, capital schools: day, evening, and Sunday Schools.l

The novelist then has Widow Green take Helen Fleetwood and her grandchildren to the city, and she finds there an entirely different atmosphere. She is sickened at the unkempt and badiy-managed household of her daughter. A neighbor, seeing her concern, describes her daughter's family:
"There's your daughter, as nice and respectable a young woman as ever came among us, turned into a stone as I may say towards her own children by harden- ing her heart to their sufferings, that she might live on their toil and ruin. There's her husband, a quiet, good-natured man, doating on his children, but forced to wink at what frets his very life. There's the crip- ple, her legs useless by the over fatigue of always standing at the frames, her arms gone by being caught in the machinery, and she in a decline from fits brought on by her suffering. Her sister--least said is soonest mended: only I can pretty well guess what sort of company she is in all the time. The boy is a devil incarnate: drinks, and swears, and cheats, and seems to hate all good for the sake of hating it. The little fellow, he is leading in the same way; and it's a mercy for the others that they died young. A short life and a sad one they had poor things, they are gone to heaven to be rewarded for it all."i2

Mrs. Tonna has another neighbor say as the widow looks at poor

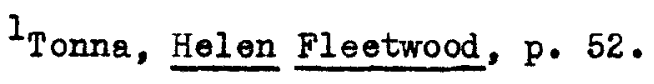

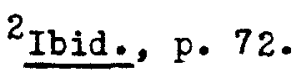


Sarah who has lost her arms in machinery:

"Everything is done by machinery; you see, they are great big things, ever so high and big, all going about and about, some on wheels running up and down the room, and some with great rollers turning about as fast as the steam can drive them; so you must step back, and run forward, and duck, and turn, and move as they do, or off goes a finger or an arm, or else you get a knock on the head, to remember all your lives. As to the sitting down; there's no such thing."I

In Michael Armstrong attention is called to the danger of children being crippled by machinery when they fall asloep at their work, and to the danger resulting from the overlooker whacking them over the heads with a "billy-roller," a long iron piece of the machinery heavy enough to kill the little ones.

The novelists feel that the master is disinterested in all this,

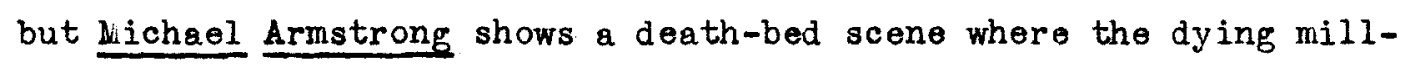
owner, sees the ghosts of factory children around him, and, knowing how he has made the children of his factory toil and suffer, tremblingly calls out to one of his helpers,

"Take them away from me, I tell you! They are all dirty, beastly factory children. Their arms and legs are all broken and smashed, and hanging by bits of skin. Take them away, I tell you Crockley! Their horrid joints will drop upon me! They are dangling and loose, I tell you!"2

In Birch Dene there is the sad story of a dear little pauper apprentice, Harney, who had his hand cut very severely by the machinery. The reader is told that if a doctor had been called immediately, the boy might have lived, but the master did not want to spend any unnecessary money, and doctors were more expensive to call in than apprentices were to find; therefore, the doctor was not called until it was too late,

ITonna, Helen Fleetwood, p. 71 .

2 Trollope, Michael Armstrong, chapter 31. 
and Westall makes the reader not only watch the little waif die a slow and horrible death, but feel with the author that the master was wholly responsible for the child's death.

Such stories of children being crippled and tortured seem almost unbelievable in a land as civilized as was nineteenth century England, but one historian filled two volumes of a work on the history of factory legislation in the first half of this century with many instances that outrival any told by these novelists. He quoted from the speeches of witnesses who were brought into Parliament to tell of the mistreatment of children. Thus the novelists were not exaggerating conditions. In one speech, Sadler, a member of Parliament, described the results that doctors told him were traceable to the long hours, scanty, irregular meals, and polluted atmosphere of the factory. He stated that the doctors

"describe the consequences to be in many cases, languor and debility, sickness, $108 \mathrm{~s}$ of appetite, pulmonary complaints, such as difficulty of breathing, coughs, asthma, and consumption; struma, the endemia of the factory, and other chronic diseases;--while if these more distressing effects are not produced, the muscular power is enfeebled, the growth impeded, and life greatly abridged. Deformity is also a common and distressing result of this over-strained and too early labour . . . Thus are numbers of children distorted and crippled in early life, and frequently rendered incapable of any active exertion during the rest of their days. To this catalogue of suffering must be added, mutilation of limbs or loss of life, by frequent accidents. The overworking of these children occasions a weariness and lethargy which it is imposible always to resist; hence, the poor creatures fall too often among the machinery, which is not in many instances sufficiently sheathed, when their muscles are lacerated, their bones broken, or their limbs torn off, in which cases they are constantly sent to the infirmaries to be cured, and if crippled for life, they are turned out, and maintained at the public cost; or they are sometimes killed upon the spot."l

I"Alfred" (Samuel Kydd), The History of the Factory Movement, Vol. I, pp. $178-179$. 
Other witnesses tell about the strapping of children with heavy leather thongs, and the maiming by the "billy-rollers."

Westall in Birch Dene has a character named Blincoe tell Robin of his experiences at another mill:

"We hajn't half enough to eat, and were a'most kicked and cuffed to death. I hadn't a sound spot on my body. Many did die. I saw one child killed"-lowering his voice. "A spinner knocked him down with a clearer (wooden roller), and he fell with his head on the corner of a carriage rail. He never spoke again, poor littlo thing! . . It was given out as the child died in a fit, and none of us durst say owt different. But it isn't as bad as that here. We mostly get enough grub; and if they put you with a good spinner, you haven't so much to fear. They don't knock big 'uns about as they do little 'uns." I

Yet in this same factory the author relates this story:

A spinner, known as Black Jack, was whiling away his enforced leisure by torturing one of the apprentices, or, as he would have said, having a "bit o' sport." A poor boy, not more than ten years old, had been forced to take of $f$ his clothes, and Jack was now trying to make him sit on a hot steam-pipe. The child struggled and begged for mercy, but he was answered only by jeers and laughter: and as his body touched the burning-iron, he screamed and writhed in agony, greatly, as it seemed to the amusement of the spinners, piecers, and others who were looking on. 2

Concerning this experience, Tom Cat, Robin's overlooker said,

"I don't hold wi' putting children on hot steampipes. But I've seen it done, and it is done. And, what is more, I've seen a lad hoisted up to a hook by his hands, wi' weights fastened to his feet, and then hided wi' a piece of thick belting till he lost his senses. I don't hold with that, nayther."3

The novelists show that the master is disgusted with such mistreatment, but is also too apathetic to interfere. Westall has Mr. Ruberry,

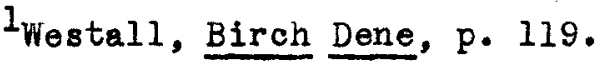

${ }^{2}$ Ibid., p. 140 .

I Ibid., p. 143 .
} 
the mill-owner, tell Robin that he didn't like such treatment, but the author shows us plainly that the mill-owner himself did nothing about it. In Helen Fleetwood, Mrs. Tonna puts these words into the mouth of one of the characters concerning the mill-owner's attitude toward the mistreatment of children:

"in the case of ill-usage, you see the master usually contrives to shift the blame from himself to the managers or overlookers, or spinners: he don't order the children to be beat; he don't see them beaten; and so he gets off, and the poor things have no protection anywhere."1

As for the health of these children, Mrs. Trollope in Michael Armstrong paints the same picture as the historian quoted above when she describes the children thus:

Lean and distorted limbs, sallow and sunken cheeks, dim hollow eyes, that speak unrest and most unnatural carefulness, give to each tiny trembling, unelastic form, a look of hideous premature old age . . The dirty, ragged, miserable crew, wore all in active performance of their various tasks; the overlooker, straps in hand on the alert; the whirling spindles urging the little slaves who waited on them to movements as unceasing as their own.2

Mrs. Gaskell, who has written two splendid books on the cotton industry described vividly and truthfully how tuberculosis often resulted from getting "fluff" in the lungs. Gentle Bessie in North and South (1854) told Nargaret Hale how she and others pot the disease:

"Little bits, as fly off fro' the cotton when they're carding it, and fill the air till it looks all fine white dust. They say it winds around the lungs and tightens them up. Anyhow, there's many a one as works in a carding-room, that falls into a waste, coughing and spitting blood, because they're just poisoned by the fluff."

\footnotetext{
$I_{\text {Tonna, Helen Fleetwood, p. } 71}$

2 Trollope, Micheel Armstrong, chapter 8 .
} 
In response to the query as to whether there is a remedy for this condition, Bessie continues:

"Some folk have a great wheel at one end o' their carding-rooms to make a draught, and carry off th' dust; but that wheel costs a deal of money--five or six hundred pound, maybe, and brings no profit; so it's but a few of th' masters as will put 'em up: and I've heard tell o' men who didn't like working in places where there was a wheel, because they said as how it made 'om hungry, as after they'd been long used to swallowing fluff, to go without it, and that their wages ought to be raised if they were to work in such places. So between masters and men th' wheels fall through." I

In Mistress Barbara, Sutcliffe says of the children working in

Ephraim Booth's mill:

There were none but children working here, yet among all those three-and-twenty faces there was not one which showed any trace of childhood. The lass nearest to him (Royd) was nodding at her work, and her hands were moving unconsciously from the floor to the box of the spinning-frame, from the frame to the floor, though the pile of wool from which she had boen foeding the machine was long since exhausted. Sleepy faces, dull and tear stained faces-all were here--but not one with any sort of playfulness, content, or hope on it. It was plain that these bairns had never played; that was the way Royd fut it to himself as he marked their stunted bodies and weary eyes--and it seemed to him the saddest summing-up of a child's life that any man could find.2

Still worse than the physical mistreatment was the moral condition of the factory children. Concerning the morals of these people, "Alfred" the historian quotes Sadler's speech on this subject:

"Not to mention minor offences, the practice of tippling and drunkenness has astonishingly increased, and has been accompanied by a revolting indecency not formerly known among us: women and children now publicly indulging in the vice; such are the degrading

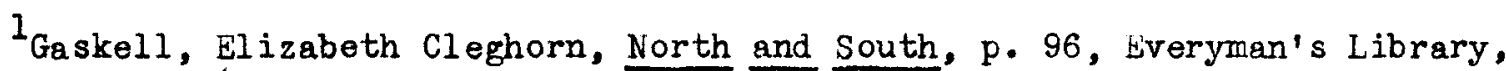
No. 680 , (J. M. Dent and Sons, London and E. P. Dutton and Company, New York, first issue 1914, reprinted 1924).

2

Sutcliffe, Mistress Barbara, pp. 121-122. 
effects of this system."I

Mrs. Tonna particularly lamented the gin-drinking habit of the children and she was bitterly opposed to the factory for so over-taxing the bodies of the little ones that they felt drink was necessary to keep them going. She says concerning this:

The child's stomach, unfitted for long abstinence, and delicately susceptible of injury, becomes doubly disordered by the privations of food and the impurities that find their way into the system from that noxious atmosphere: it loses all desire of wholesome diet, and craves the exciting draught that shall lend a transient stimulus to the frame unstrung by toil, and chilled by the sudden transition from the heated pandemonium of the mill to the raw, keen air of night; the poor little victim who reels from exhaustion as it enters the gin-shop, reels thence a drunkard.2

A little farther in the book Mrs. Tonna has her spokesman talk

about the various evils of the factory system:
"They grow up in the mills from childhood to manhood--that is, the very few among them who live to men and women--and all the change of character they undergo is from bad to worse; from being learners of wickedness to being teachers of it - Those about them are all of one class, and they may lie, they may steal, they may drink, they may make themselves no better than the beasts of the earth, so long as they work out their hours of labour, keeping time with the machinery, and don't openly wrong the employer. Indeed, where there is so much wickedness it's more for their comfort to be like the rest: anyone trying to withstand bad example, and to act a good one, like yon poor girl Helen, must expect that if she don't choose to blacken her mind, they'll blacken her name. Such a rookery of crows can't bear a white dove among them - - If you think me uncharitable, just ask your- self what you would most likely now be if you'd never heard a syllable of good advice, but curs- ing and swearing, and filthy talk from morning to night: then to go home, so tired you had no thought for anything but to get to sleep as fast

I"Alfred" (Samuel Kydd), The History of the Factory Movement, Vol. I, p. 185. 2 Tonna, Helen Fleetwood, p. 95. 
as could be, and up again for the same purpose. This to go from Nonday morning to Saturday night, and Sunday the only play-day you had--the only day when you might, by taking a stroll--satisfy yourself that the world is not made entirely of brick and stone."I

Just as the morals of the children were sadly neglected, so also was their education neglected. Children of poor parentage had never been privileged to attend school even before the days of the factory system; their education had consisted solely in learning the craft or trade of their parents; therefore, the parents did not care about sending their children to school during the years immediately following the advent of the factory system.

When there were not other means of keeping working-class children under supervision and giving them some sort of training, their parents not unnaturally set them to work at an early age. But when, finally, elementary education became compulsory, and there were definite claims upon the children's time, it became very much easier to prevent the employment of those below the legal age, and to enlist parents upon the side of the law. Apart from any other benefit which education conferred, it did check the extensive employment of children at an age when long and constant labour must, according to the present opinion, be deleterious. Until 1876 initiative in education had rested with private bodies; for though various of the Factory Acts, from 1802 onwards, required employers to provide education for their juvenile employees, the clauses imposing this obligation were frequently not enforced, or, where they were nominally complied with, the education supplied was often a mere farce.2

This method of evading the education of children is another point that Mrs. Tonna discusses in Helen Fleetwood. She does this in a splendid manner by having her spokesman, Tom South, who is himself a factory worker,explain and answer questions for widow Green who has always lived

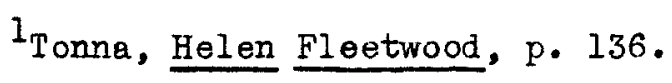

2 Dunlop, 0.J., and Denman, R. D., English Apprenticeship and Child Labour, A History, pp. 293-294, (Macmillan Company, Now York, 1912). 
in the country until she moved to the factory district to let her grandchildren work in the mills. Not only does South tell about the schooling, but he throws light on some of the background history at the same time. This is Mrs. Tonne's method of enlightening her reader and accomplishes, in part, her purpose in writing the novel. Mrs. Tonne differs from the other novelists discussed in that she does not use any characters from a higher class of society. She makes Tom South, a reasoning character, state factory conditions and deplore the low standards of the factory system. She also makes the Widow Green of an inquiring frame of mind, anxious to do her best for her grandchildren. Tom South acknowledges to Widow Green that there is a law that every child should go to school twelve hours a week, and have a ticket to show that he has been,

"but when it comes to the pass, how do they manage? Why, they give them an hour's leave or so at such times when no school is open, or else when there's only schools within reach where the masters and mistresses won't receive the little dirty wretches, covered with the filth of the mill, among their children. Then, to make out the twelve hours, they tell them to go to school on Sund ay morning, ofternoon, and night, as if the poor creatures did not deserve a day's rest, to say nothing of play: of course they won't go."

In response to the question as to how the children get vouchers under such conditions, he proceeds:

"They forge them fast enough, but in a great many mills they are allowed to slip in without any, and the owners that have a conscience above that, turn off the young hands rather than the work should be stopped. Then the children go to the silk-mills, wher $\theta$ they are taken in at any age and worked to death."

Widow Green asks about the inspectors discovering these deceptions as to the schools and punishing the offenders. South replies:

"The inspector comes once a year and is bound to advertize his coming in the newspapers; so they 
take care to have all right just then. But if a complaint is made, and proved too, this fine law allows the father or brother of the of fender to try the cause, and gives him power to dismiss it, if he likes." I

Considerable light is thrown upon the difficulties which reformers had to face by the fact that it was considered necessary to insert a clause to the effect that owners of mills, or their fathers and sons, were incompetent to hear cases under this $\operatorname{act} .2$

Mrs. Tonna was anxious to be perfectly fair and truthful. Since she knew that there were some sympathetic and understanding mill-owners who wanted to live according to the law, who wanted to give their little factory workers an education, she had South say:

"Some of the mill-owners have established schools on their own ground, which are in the main fairly conducted; but where this is not the case, the poorer children are obliged to find them where they can, and I am sorry to say the one you have visited is a specimen of a numerous class, where the chief, nay, the only trouble incurred by the nominal teachers is to give bits of paper, certifying the attendance of the child for two hours per day. A few pupils obtained from the families of snall tradesmen around, pay well and get what they bargain for: but with respect to our poor little factory people, standing room, or at best a few benches to sit down on, with the privilege of handling some books of the kind you saw, is all they can expect. However, as I remarked, this is only one class, frequented by the most neglected of the children; we have very respectable schools in various parts of the town." 3

He admitted that laws had been made and that some benevolent people were trying to improve matters, but he felt that most of the mill-owners did not like the interference, and co-operated as little as posible.

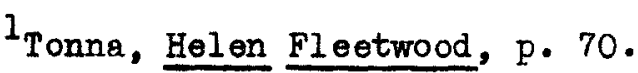

${ }^{2}$ Dunlop, 0. J., and Denman, R. D., English Apprenticeship and Child Labour, A History, p. 288 .

3 Tonna, Helen Fleetwood, p. 115.
} 
The author has South continue to inform the reader through his conversation with widow Green about the difficulties under which the inspectors in this period labored. It is clear that Mrs. Tonna has studied. the factory conditions and has much data at her finger tips. She states through the conversations of the factory workman, South, to the Green family that the inspector had eighteen hundred mills to superintend, which were spread over a large and almost inaccessible area; he had only four assistants or superintendents to visit each mill, very hurriedly, three times a year. The superintendent had not even the power to enter a mill if the owner did not consent, and if he heard something that was wrong he could not insist on an investigation of it; he could only send word to his superior for his inquiry into and punishment of the wrong. The inspector himself could not interfere if the matter complained about had occurred more than two weeks before the time the superintendent discovered and reported it. The inspectors were supposed to watch especially for overwork of the children and hands. Even though the inspector and the superintendent both realized that the master's time-books were often unfairly and inaccurately kept, they had no time on their hurried visits to look for discrepancies in the bookkeeping, and the mill-owner, who always knew when the superintendent was due at the mill, would naturally have everytring in smooth running order two weeks before his arrival, and in this manner avoid punishment for his evasions of the law. Mrs. Tonna has South tell how the mill-owners cheated about the time:

"They cheated the children out of their proper hours for meals and schooling by altering the clock, and other contrivances; and if they wanted to keep all hands at work half-an-hour or longer, after regular closing hours, they would loosen a pin or a strap in the morning, stop the machinery for a few minutes to set it right, and then, under shelter of the very 
act they were breakjng, detain them at night to work up lost time."I

One historian states that by the act of 1833 , the four government-appointed inspectors

had full power of entry into factories, and could make such rules and by-laws as they considered necessary. Henceforth there was a chance that the acts would be enforced. "The introduction of an external authority, free from local bias and partiality, greatly improved the administration of the law, lessened the friction between manufacturers and operatives, and provided a medium of communication between the government and the people at a time when a knowledge of industrial matters was scanty in the extreme." The provisions of this act were sound enough, but the inspectors found it well-nigh impossible to enforce them, because machinery could be kept running, and adult labour could be employed for longer hours than were allowed to children, and it was therefore very easy for the manufacturer to keep boys and girls at work after they should have been sent home.

New problems of administration, of course, challenged the inspectors at each new advance in legislation. The restriction of working hours of children to twelve a day had led many employers to institute a relay system, which made detections of law violations difficult. 3

Later "Charlotte slizabeth" has the character South discuss the manufacturer's method of turning court trials in his favor, for she has Widow Green bring her granddaughter's and Helen's wrongs to the notice of the superintendent, has him do all he can, but the over-looker is acquitted, the mill-owner is given only a small fine, and the girls lose their jobs. Concerning this, Mrs. Tonna has south tell Richard Greene, who has just come from the country to see Helen,

ITonna, Helen Fleetwood, p. 107.

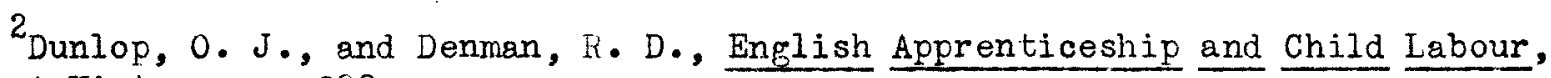
A History, p. 289 .

3 Andrews, John B., British Factory Inspection--A Century of Frogress in Administration of Labor Laws, p. 5 . 


\begin{abstract}
"There the inspector did all that the law allows; he searched out for the cases of injustice, brought them to as fair a trial as he could obtain, and as it was impossible he could stop to superintend it, he placed the matter in most respectable, honourable hands, and gave every help in his power; yet you see the result; and I need not remind you how they baffled him, by intimidating one set of witnesses, brow-beating another, influencing a third, slandering a fourth, perplexing the silly children, quibbling about words, shifting the responsibility from party to party, as in the case of the surgeons' and magistrates' certificates, and finally making sure of a partial decision by putting a near relation on the bench. Self interest - . is a strong feeling in man; and the laws are to be blamed that leave the owners at liberty to go such lengths where it leads them. Nany an honourable, kind-hearted man is drawn away insensibly to do, for his own interest, what he would never think of doing if the fact of its being allowed by the laws, and being done by his neighbors, did not make him look on it as a sort of thing of course, a necessary evil--an act of injustice done by so many that his refraining from it would only ruin himself, without taking anything worth mentioning from the amount of public harm."I
\end{abstract}

But

by the close of the century the most tangible abuses of child labour--early employment, brutal treatment, and over-long hours, and the other injurious conditions against which the nineteenth-century reformers had declaimed--had either disappeared or were greatly modified . . Effective laws were not passed until the outcry of the extremists as to the horrors of child slavery had awakened the emotions of our legislators. To o considerable extent, in fact, reform was sentimental.2

And these novelists have contributed their bit by awakening the emotions of the reading public to the wrongs done the factory child.

The work of the women was not usually hard, but work in the mills was detrimental to their health and morals.

Mrs. Trollope has one girl faint from over-exertion and heat, and die because she was kept at work. The people were so aroused that a strike was imminent. She has Sir Hatthew, in speaking of this to his

$I_{\text {Tonna, Elen }}$ Fleetwood, p. 137

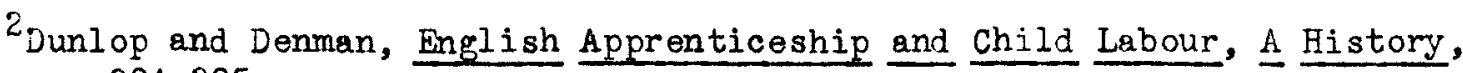
pp. 294-295. 


\begin{abstract}
foreman, Parsons, say:
"The people, old and young, our own people, I mean, have one and all, taken dudgeon about that girl Stephens, that died the week before last, just after leaving the mill. She had been at work all day in the spinning-mill, and who was to guess that she was that low? It was a $d--d$ stupid thing, Parsons, to have a girl go on working, and not know whether she was dying or not"... "That's not the question, Sir Matthew, asking your pardon. There's no great difficulty in finding out whether they are in a real faint, or only making most of being a little sickish from standing, or want of air. That's not the difficulty. The thing is to know, when they really take to the downright fainting, whether they are likely to live through it or not." "Tis the rousing up of people's attention, again, Farsons, there's the danger." 1
\end{abstract}

This account shows that not only is it difficult and detrimental to health to work in a high temperature but more important, that there is a lack of humane feeling on the part of the mill-owner and the foreman. Nrs. Trollope makes it clear the master is interested in the death of this girl solely because it fanned the flamie of discontent in the people.

In Helen Fleetwood, it is against the constent hurrying that Mrs. Tonna has Helen complain:

"There is no resting in a mill, for nobody can stop the great wheels always kept going by the steam. ly work is among much bigger machines than liary's, in the carding-room, where the cotton is pulled out and prepared for the spinners... There'is plenty of bustling, and crowding, and hurrying, but the work
does not seem very hard."

In this carding-room, however, it is so hot that women faint, and Mrs. Tonna has little Nary Green tell her grandmother concerning Helen's fainting,

Irollope, Michael Armstrong, chapter 3 .

2 Tonna, Helen Fleetwood, p. 78. 
"they say it is such a common thing in Helen's room, owing to it being the hottest and most fatiguing of all, that nobody minds it."l

Mirs. Tonna has Helen say concerning the master and overlooker, granny."

"There is not much feeling in a mill, dear

This same writer is bitter against the low moral standard of the women. She has shown the sad plight of the factory children, and she wants each reader to understand how much greater is the effect of the heated, crowded conditions and the bad language on the outlook and attitude of the women workers. She paints at length the persecutions of the character who tries to stand for the right amid all that is ugly and repulsive, and has her say to her grandmother,

"Our fingers are employed and our feet, too, but our tongues are free, and all the mischief that bad tongues, prompted by evil hearts, can do, is carried on, to the ruin of the work people, but not to the hindrance of the work. All that the over-lookers care for is to see everybody feeding the engines, or drawing out the cotton, winding, piecing, and all the rest of the business. And besides,"--she hesitated, looked more distressed, and then added,"you are greatly mistaken if you think the men who overlook our work care for our morals--they themselves are often the worst of the bad."3

Mrs. Tonna makes this picture still more vivid by contrasting these women in the factory with the daughters of the mill-owner, and then she has Helen say of them:

"Mr. Z. I know has daughters growing up: would he send them among us for an hour every day? Not he. He knows too well that their health would be destroyed by staying even so long in the heat, the steam, the stench, and the dust of the rooms where we are pent up from early morning to late night; and he knows that they would never again be let into respectable society if they were supposed to hear the

1 Tonna, Helen Fleetwood, p. 153.

2 Ibid., p. 91 . 3 Ibid., p. 90 . 
vile, filthy talk that his poor labourers use, and the men he sets over them encourage; and which he never dreams of checking, either by his own presence, or by setting any moral, not to say religious person, to watch them. I wonder if $M r . Z$. thinks there are two heavens, one for the masters, another for slaves, or how he expects to escape the reproaches of his victims, if both should meet in the place where God has declared that the covetous as well as the abominable shall go."l

Sutcliffe, after speaking of the children's misery says:

nor were the children in the worst case; their minds were mercifully numbed, and outrage could not hold for them the bitterness it had for the grown women of the parish. The very attitude of the moor-folk toward a factory-girl was proof enough of what went on; for to say a man's daughter went to the mill, was to say, almost to a surety, that the master had robbed her of more than sunlight and free air.2

Yet each of these novels gives the impression that one of the worst evils of the factory system is the monotony of the work. Perhaps that is behind all the brutality, low standards, and weary attitude of the workers. Westall has Blincoe, a pauper apprentice, summarize this when he tells Robin in Birch Dene the reason he tried to run away:

"It is the long, weary hours, piece, piece, piece, week after week, year after year, all day long; no hope, no rest, no change, nowt but piecing ends--factory and bed, bed and factory--nobody to care for you nobody to say a kind word to you!" 3

But Westall does not leave the feeling that conditions are irreparable; he shows some of the things a kindly, sympathetic mill-owner can do to help the situation. He has Mr. Ruberry clean the apprentice house, build a hospital for the apprentices, and hire a nurse to look after any children who are sick or who have been hurt at the factory.

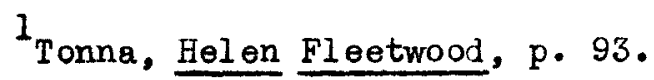

2 Sutcliffe, Mistress Barbara, pp. 136-137.

3 Westall, Birch Dene, p. 151. 
He gives fairer wages, and treats the hands as human beings.

Mrs. Tonna sees the solution to the factory ills in politics and legislation. She feels that it is against the indifference in the legislature that the battle must be waged and that this can be overcome best by quietly and peaceably instructing the women and mothers of England, and having them in turn urge the matter to the attention of their husbands and acquaintances. Mrs. Tonna could not understand how the English women could be anxious to help the children in heathen lands and yet could sit quietly by, ignorant of the need among the factory children in England itself. And she closes her novel by having little Mary say to her brother:

"Oh, Richard, we should pray for those men who are trying to make the factory children less miserable; and whenever you speak to the great folks, put in a word: for I can't help thinking God must be angry with them while they take so much care about their own little ones, and have no thought, no feeling for the perishing children of the poor!l

Mrs. Trollope finds the solution to the difficulty in a ten-hour day at the same wages, brought about by an act of Parliament. She feels that not only would this help the tired, overwrought bodies of the women and children, but that the shorter hours would make it necessary for the millowner to employ more men and thus keep the fathers from idly waiting to take their children's wages. The children would have more time for school and Sunday-school, and the mothers more time and energy to devote to their household duties, and to mending and remaking the old clothes which, under the system then in use, were always in rags and tatters. She has Miss Brotherton, the heiress, do everything in her power to help the factory children. In fact, it was not many years after this book was written,

1 Tonna, Helen Fleetwood, p. 184 . 
that the ten-hour day was put into effect by legislation. 1

After this time, the novelist felt that the need for his tal-

ents lay in a slightly different direction, and he no longer centered his attention on the women and children, but became interested in the worker in general, and in his struggles against the master.

These four novelists all want to raise people from their lethargy regarding the factory women and children and the two who wrote during the "hungry forties," the time of such stress and poverty for the poor, felt that legislation was the urgent need of the day. All of these books are emotional and sentimental, but the stories are told vividly and acquaint the reader with conditions as the author really believed them to be.

This study of the treatment of factory women and children shows that, when checked by historical evidence, the novelists have, in most respects, given a true presentation of conditions. The chief aim of the authors was to let the reader look into the work, the home, the heart of the factory worker, and see the difficulty there. The pictures are sad, many of the characters suffer greatly from disease, persecution, trials, but they have gone steadily forward, onward, upward. Helen Fleetwood went to her heavenly reward, but only after she had helped many of her fellow workers to want to lead better, cleaner lives; kobin took his place in the community and the business world; Michael Armstrong became a fine, outstanding young man.

The authors believe that much can be done to help the workers if the reader will sympathize, do his part to shorten their hours, and above all, think of the operatives not as slaves, but as human beings .

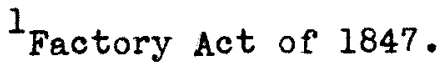


That some good was done by the two of these novels written during the first half of the century is evidenced by the fact that "Alfred" the historian says of them:

Mrs. Trollope's novel Michael Armstrong has been much abused; it has, however, been useful, and so, also, has been Helen Fleetwood by Charlotte Elizabeth.l

I"Alfred" (Samuel Kydde), The History of the Factory Movement,
Vol. II, p. 295. 
CHAPTER III

The Problem of Labor Organizations and Strikes 


\section{CHAPTER III}

The Problem of Labor Organizations and Strikes

A third problem treated in the novels is that of labor organization. Historically, labor had organized earlier, but it did not become a dominant problem until the middle of the century. Accordingly, the literary treatment of the factory, in which labor development is the central consideration, falls mainly into the period since 1846 .

The beginnings of labor organization before this time are reflected in two literary treatments. These beginnings and their treatment in fiction will be reviewed briefly before a more detailed analysis is made of the froblem of labor and its treatment in fiction.

Often people speak of the trade union as dating from the middle of the nineteenth century. It is true that our modern unions did begin then, but long before that workmen had combined in an attempt to fix wages.1 Because of this, the combination acts of 1799 and 1800 made it illegal for any group to combine for a discussion of trade and labor, but these acts suited neither capitalists nor laborers and were not rigidly enforced. Neetings for such discussions were termed "institutions" instead of "combinations," and the law was evaded.

At first the unions wanted legislation and did not try to force the issue by strikes, but when wages fell and prices rose, poverty and suffering caused a serious strike among the cotton spinners of Lancashire in 1808; this, however, availed nothing because the strikers were not well organized. In 1811 the rapid output by machinery overstocked the

1 Traill, H. D., Social England, Vol. V, p. 342 . 
market and prices rose so high and wages fell so low that the laborers united to cause havoc for the manufacturers. Hention was made in the first chapter of these riots and the novels dealing with them.

After this, strikes and riots were common, for the laborers found that the state would not help them and that they must combine to help themselves. In 1824 the laws on combinations were repealed, but so many strikes followed that Parliament allowed no combinations except peaceful associations formed by the laborers to deal with questions of wages and hours of labor. Trade unions multiplied, but accomplished little, for a strike was their only weapon.

Two works of fiction deal with this mid-period in the growth of the labor movement. Mistress Barbara (1901) by Haliwell Sutcliffe, mentioned in the preceding chapters, deals with the labor situation and the question of a strike in 1826. A Manchester Strike (1833) by Harriet lartineau is a nerrative on political economy, and deals with the period in which it was written. Both of these novels, although sympathetic with labor, look at the problem from the side of the philanthropic capitalist.

Niss Nartineau was an outstanding woman writer of her time, and this narrative is of interest because it is the first fiction written on factory conditions. It is, for a story on political economy, written interestingly.

One day Miss liartineau canie across hrs. Marcet's "Conversations on Political Economy," a subject about which Wiss Martineau then knew nothing, but which interested her. It was

not a subject that had much appeal for the masses; but why not make it appealing? As she read Mrs. Marcet's exciting pages, characters illustrating the various Economic principles rose up from them. She could give profit and loss all the glamour of fiction.. The thought of the toiling multitudes 
who "needed" nay "craved" for--the "Series" gave her courage. 1

The stories
consist of a mixture of elementary, borrowed, half- baked and undigested science served up in the form of dull fiction wholly without a redeeming feature. But she had chosen the right moment. Reform was in the air. The Reform Bill was the dominant political question; young $\mathrm{kr}$. Dickens was beginning to attack social abuses, and the demand for education was mak- ing itself heard . . She explains at great length her miethod of writing it, which, she frankly admits, was to get from the library every book she could dis- cover concerning the particular number she happened to be writing and borrow her material, not troubling herself with any other branch of the subject until she needed to get it up.?

The author is very much opposed to strikes. Yet she shows that the employers often were uncompromising and antagonistic to their employees, and were not even willing to attend a public meeting to discuss measures for a peaceable agreement. On the other hand, she shows that few of the workers knew why they were striking and guve such reasons as "No potato peelings!," "Reform and good wages!," "Liberty and cheap bread!"

The story centers around the workman Allen, a friendly, intelligent counsellor of those in distress. He was not anxious to strike, but since the Union seemed to have the interests of the operatives in mind, he was willing to sacrifice his ideas in order to have unanimity. Since he was a married man, he was loathe to become the leader of the strikers and thus bring down the ire of the masters on his head, but his sense of duty to his fellow workmen made him accept the office. Miss lartineau shows the tragedy and suffering that was his because of this leadership. And when the strike failed, the manufacturers would not hire him because of his prominence during the strike, and he, a good, steady workman, resorted

\footnotetext{
${ }^{1}$ Colson, Percy, Victorian Portraits, p. 186, (Rich and Cowan, London, 1932). Ibid., pp. 191-192.
} 
to street-sweeping for a livelihood.

The author gives her opinion by the speeches of a kindly manufacturer, Mr. Wentworth. He tells the workmen in a mass meeting called to discuss the need for a strike that the choice of lowering wages rested neither with the masters who hold the administration of capital, nor with the government, but with the administration of labor, and he said that much greater power was in the hands of the laborers, for as capital increased, the number of laborers increased also, and the proportion of wages had to be less if the masters were to have a profit. liss Martineau felt that when there were fewer workmen than were needed, the men and not the masters were the powerful factor, but when generation after generation reared large families and all had the same trade, wages must consequently fall lower and lower. She makes this sympathetic owner say:

"hy object is to prevent your making a bad case worse, and, if it were possible, to persuade you not to prepare for your descendants a repetition of the evils under which you are yourselves suffering. All that you can now do is to live as you best may upon such wages as the masters can give, keeping up your sense of respectability, and your ambition to improve your state when better times shall come. You must watch every opportunity of making some little provision against the fluctuation of our trade, contributing your money rather for your mutual relief in hard times than for the support of strikes. You must place your children out to different occupations, choosing those which are least likely to be overstocked; and above all, you must discourage in them the imprudent, early marriages to which you are mainly owing the distresses which afflict yourselves and those which for some time, I fear, will oppress your children."I

Because the author could see that strikes would not in any way help the situation, but could hinder the workman's cause by wasting money, she was against the strike. She thus summarized her views:

$1_{\text {Martineau, Harriet, A Manchester Strike, p. } 150 \text { in Illustrations of }}$ Political Economy, No. 7 , (Leonard C. Bowles, Boston 1833). 
Combinations of laborers against capitalists (whatever other effects they may have) cannot secure a permanent rise of wages unless the supply of labor falls short of the demand;--in which case, strikes are usually unnecessary. Nothing can permanently affect the rate of wages which does not affect the proportion of population to capital. Legislative interference does not affect this proportion, and is therefore useless. Strikes affect it only by wasting capital, and are therefore worse than useless. Combinations may avail or not, according to the reasonableness of their objects. Whether reasonable or not, combinations are not subjects for legislative interference; the law having no cognizance of their causes. Disturbance of the peace being otherwise provided against, combinations are wisely therefore now left unregarded by the law.

The conditions of laborers may be best improved, --1 st. By inventions and discoveries which create capital; 2nd. By husbanding instead of wasting capital;--for ins tance, by making savings instead of supporting strikes; $3 \mathrm{rd}$. By Adjusting the Proportion of Population to Capital. I

Mistress Barbara, although written at the beginning of the twentieth century, refers to the unrest of the factory workers during the early days of machinery when times were hard. The author contrasts the life of the manufacturer with that of the landed gentleman, and the business methods of the shrewd but kindly master with those of a hard, grasping one. The young woman, Barbara, daughter of the squire and loved by the mill-owner, is the connecting link between the two classes of society. Sutcliffe pictures the old-type factory of 1825 :

The wool was all combed by hand outside the precincts of the mill; it was woven by hand, likewise, in one or other of the moorland cottages; all that the mill had to do was to spin the delicate threads of these white combings into yarn--and brown peat water, fresh from the windy uplands, did al] the hard work that was needful.2

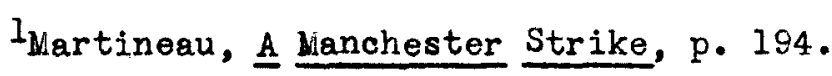

${ }^{2}$ Sutcliffe, Halliwell, Mistress Barbara, p. 74, (T. Y. Crowell and Company, New York, 1901). 
A strike was brewing among the workers because they received less

than a living wage. Royd paid fair wages and worked the employees only ten hours a day; Booth, the task-master, paid only a mere pittance in wages, and worked the children sixteen, eighteen, even twenty hours. Yet sutcliffe says of Booth:

He was in no sense a villain. It did not give him pleasure to see the children's backs grow bent, their faces red with weals; his pleasure was solely in seeing his overlooker get the most work from them that they could give, and cruelty would have seemed wrong-doing to him only if he had been farsighted enough to see that in the long run it would not pay. He could not be judged by any usual standard; he was rather a machine of wood and steel, turned by the power of greed; he referred all issues to the final test of brass; brass was the word most often on his tongue, and his belief in it was sincere as other men's belief in God. 1

The author paints the unreasonable attitude of the mob when he

shows the workers gathered at the inn to discuss the strike:

The murmurs grew articulate at last; tales of want, tales of cruelty, tales of stark lewdness in the factories, were told in the blunt, unstudied words of fact. And Stephen Royd, now that the blood was up and their reason in abeyance, was made to bear the brunt of all; cruelty and want, the sobbing of the little children and the tearless desperation of the women--the mill-masters stood at the head and fount of all these matters, with the over-lookers, whip in hand, beside them. There could be no distinction now; hoyd's gentler dealings were forgotten--he was master; he had shared the masters' past prosperity; he must share with them in what the future held.2

However, the manufacturers did not combine to strengthen their position.

There was no union of the master-weavers in karschotes and Ling Crag with those of the bigger towns; they were a race to themselves, trading in their own fashion in the lonely cleft of moor that harboured them, and even in their own cormonwealth they were not united, but fought each for himself,

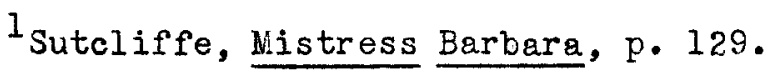

I Ibid., pp. 212-213.
} 
neither giving nor demanding help from one another. 1

But the laborers had an agitator among them and Sutcliffe has the manufacturer, Royd, show his utter disgust of such a person. He says to the agitator in the workmen's hearing:

"Times are bad, you say; then where does your money come from? We masters don't feed you; you won't work to feed yourself; how do you get money to provide wheaten bread, and meat twice a day, and clothes that are too good to work in? . . How do you live, I ask? Why, on the alms of better workers than yourself; you're a beggar, thriving on the discontent you rouse, $--a$ fellow who creeps into honest houses, and whines about hard times, and gets well paid for it. you've had much to say of me in Ling Crag; well, if I lost every penny to-day, I could turn to the loom, or to the combing-pot, and earn my bread as well as any man who stands here. But could you? If there were no fools to listen to you, would you thrive or starve?"2

The author has Royd avert the strike. He enters the inn, releases his overlooker who is about to be tarred and feathered by the laborers, fights the leader, fells him, and questions the mob in no gentle tones. He asks them how far their money would go, how long it would last, where they would find work when they had beggared the one who gave them money and work. Sutcliffe feels that this is the way the manufacturer should deal with strikers; that is, to make them realize he was master in more than name, and yet one of them; to measure their strength, and then fling himself against them, will against stubborn will.3

This novel shows that trade unionism is still in its infancy and the power of labor still latent.

But by the middle of the nineteenth century, the laborer began to feel his power. Two reasons for this were the passage of the factory acts and the repeal of the corn laws. The factory acts from

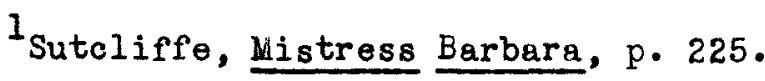

2 Ibid., pp. 105-106.

3 Ibid., p. 220 .
} 
1802 to 1847 helped the laborers by making their hours shorter and by compelling the manufacturers to be more humane to their employees. The corn laws which were designed to make kngland a corn-growing kingdom and to regulate internal trade by fixing a price above which export was forbidden, became a serious problem in the early part of the century. Bad harvests from 1839 to 1846 brought about famine, and the "hungry forties" were hard on the laborers in the factories, for they depended on the farmer for their grain. These laws were repealed in 1846, and this pared the way for the establishment of free trade which helped manufacturing by opening foreign markets for trade.

The realization of the laborer's new power led sone of the union leaders to study more about economic subjects. As a result they began to denounce strikes. Instead of one national organization, they now formed separate unions for the different trades, with local branches, self-governed, but subject to a general code and centralized in an executive committee. Each union now took care of its own interests, though at times kindred unions helped each other financially if the need arose. Capital naturally opposed any effort at the legalization of the trade unions, and, since severe violence and outrages resulted from the unions, public opinion was now strongly against them. This was shown especially in the "Sheffield Uutrages" of 1866.1 However, it was shown that the trade unions could not be proved responsible for all this trouble. In 1867 a Royal Commission was appointed to inquire into the question of the trade unions and to discuss the differences between capital and labor. The Commission heard representatives of both sides. Since witnesses for the unions endegrored to stress the friendly society aspect of the unions, and those opposed to the unions showed an uncom-

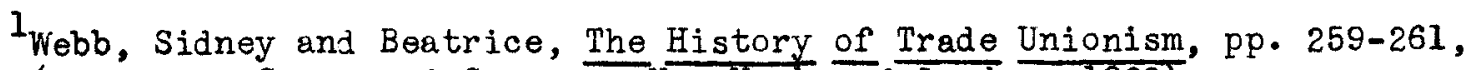
(Longmans, Green and Company, New York and London, 1920). 
promising attitude toward labor, the Cornnission advised that legal protection be given the unions, but opposed any violence by union men either to employers or to fellow workmen. This, however, would not even allow peaceful picketing.

Legalization of trade unions was extended further in 1875 by an act stating that no action of a union was punishable unless the same act was criminal if committed by a single individual. Unions were now powerful and sprang up everywhere. The laborers hoped that such devices as boards of conciliation and division of profits would end the war between capital and labor, but the capitalists demanded still greater reduction of wages and longer hours of work. Strike after strike resulted, but the laborers were usually defeated. A new unionism had asked the state only to allow them to combine and to protect their property. This new order wanted an eight-hour day, municipal organization of work-shops, and even looked forward to nationalization of land and instruments of production. It looked upon the union as a fighting machine. 1

By 1890 , a rate of wages for each industry was established by the union, but even this did not give the union sufficient power. Not until the twentieth century did labor compel capital to listen to its demands, and very few tangible results were shown until after the world War.

The novels that deal with labor organization since the middle of the nineteenth century are: Mary Barton (1848) and North and South (1854) by Elizabeth Cleghorn Gaskell, Hard Times (1854) by Charles Dickens, Put Yourself in His Place (1870) by Charles Reade, and The Story of Stephen Compton (1912) by John Edward Patterson. Brief mention is made in this

\footnotetext{
$1_{\text {Traill, H. D., Social England, Vol. VI, p. } 613 .}$
} 
chapter of three other novels but there is very little antagonism shown between capital and labor. These novels are: probation (1880) by Jessie Fothergill, Thyrza (1887) by George Gissing, and Paul Nercer (1897) by James G. Adderly.

A study of the treatment of labor organization in these novels shows a four-fold purpose on the part of the authors: first, their conception of the antagonism between capital and labor, secondly, the methods employed by each side to gain its end, thirdly, the effects of these methods on those concerned, and fourthly, attempts at a solution of the problem. Each novelist shows a sympathetic attitude toward the laborers. None of these writes from a proletarian point of view.

The outstanding novelist of this group from a standpoint of the factory novels, is Elizabeth Cleghorn Gaskell, wife of a Unitarian minister. Around her in Manchester, according to the Preface in Nary Barton, she saw a constant battle between capital and labor. She saw the povertystricken home of the laborer on the one side, and on the other the fine home of the capitalist. Since she felt that she could voice the woes of the people and enlighten the public, she wrote the novels Mary Barton and North and South. This study will center around these novels which show a keen interest in the laborer's reactions, a strong love of mankind, a sympathy for the down-trodden, a sense of justice to all, and a realistic approach. These novels caused great interest at the time of their appearance because there was a strong feeling regarding the two opposing classes of English life. Mrs. Gaskell wrote these novels just a few years after Mrs. Trollope and Mrs. Tonna wrote their novels on the treatment of women and children in the factory, but by the time vary Barton was written, the burden of the women and children had been lightened greatly by legislation, and the question uppermost in the minds 
of the writers was the great opposition between capital and labor.

Mrs. Gaskell was urged by her husband, after the death of their little son, to turn to writing as an outlet for her emotions. She had been sympathizing with the people around her, she had been endeavoring in a small way to alleviate their bitterness and want, and when one workman asked her the question: "But have you ever seen a child clemmed to death?" it burned in her soul, and, coupled with her own sorrow, gave her an opportunity to show the sorrows of those around her. In the preface of Mary Barton, written in 1848, she explains her feelings:

I bethought me how deep might be the romance in the lives of some of those who elbowed me daily in the busy streets of the town in which I resided. I had always felt a deep sympathy with the careworn men, who looked as if doomed to struggle through their lives in strange alternations between work and want, tossed to and fro by circumstances, apparently in even greater degree than other men. A little manifestation of this sympathy, and a little expression of feelings on the part of some of the workpeople with whom I was acquainted, had laid open to me the hearts of one or two of the more thoughtful among them; I saw that they were sore and irritable against the rich, the even tenor of whose seemingly happy lives appeared to increase the anguish caused by the lottery-like nature of their own. Whether the bitter complaints made by them of the neglect which they experienced from the prosperous--especially from the masters whose fortunes they had helped to build up--were well founded or no, it is not for me to judge. It is enough to say that this belief of the injustice and unkindness which they endure from their fellow-creatures taints what might be resignation to God's will, and turns it to revenge in many of the poor, uneducated factory workers of lanchester. The more I reflected on this unhappy state of things between those so bound to each other by common interests as the employers and employed must ever be, the more anxious I became to give some utterance to the agony which, from time to time, convulses these dumb people; the agony of suffering without the sympathy of the happy, or of erroneously believing that such is the case. If it be an error that the woes, which come with ever returning tide-like flood to overwhelm the workmen in our manufacturing towns, pass unregarded by all but the sufferers, it is at any rate an error so bitter in its consequences to all parties, that whatever public effort can do in the way of merciful deeds, or helpless 
love in the way of widow's mites could do, should be done, and that speedily, to disabuse the workpeople of so miserable a misapprehension. At present, they seem to be left in a state, wherein lamentations and tears are thrown aside as useless, but in which the lips are compressed for curses, and the hands clenched and ready to smite. 1

Therefore, Mary Barton is a story of woe. It deals with the gradual degeneration of the character, John Barton. At first he is shown as a kind father and good, sober workman, but suffering and poverty drive him until in his madness he becomes the murderer of the capitalist's son. Of lesser importance is the rise in character of the heroine, liary Barton, from the role of an average factory girl to that of an outstanding young woman broadened by suffering and adversity. Her love affairs with both the mill-owmer's son and an honest young workman, weave the story together.

In this story the author shows her familiarity with the life she depicts. Because the reader feels that hrs. Gaskell has, by keen realism, shown the necessity for understanding between capital and labor, because each character as she draws it savors so strongly of truth, these novels command attention, and demand a respect for such a writer as Mrs. Gaskell. Above all else, Wrs. Gaskell wanted to be fair to both classes, and when, a little later, she realized that many capitalists were not so aloof and disinterested as she had painted the capitalist Carson, in Mary Barton, she tried to show in another novel, North and South, the kindly but determined manufacturer.

Nary Barton, however, is a defence of the working class, to show what the laborer really thinks. The author shows the stolid endurance of these people, their unselfishness for the weakest in the family,

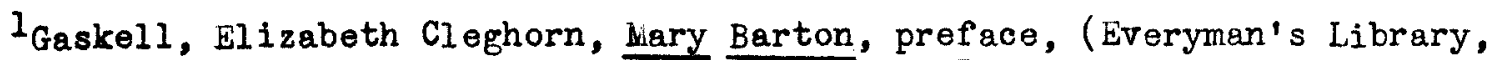
No. $598, J$. M. Dent and Sons, Lond on, and E. P. Dutton and Company, New York, first issue 1911, reprinted 1924 and 1932). 
their neighborly kindnesses, their joy in receiving company into their poor little homes. Yet Barton, the murderer, was a part of this group. Concerning this, Mrs. Gaskell writes:

To intimidate a class of men, known only to those below them as desirous to obtain the greatest quantity of work for the lowest wages, - at most to remove an overbearing partner from an obnoxious firm, which stood in the way of those who struggled as well as they were able to obtuin their rights,--this was the light in which John Barton had viewed his deed.l

The author shows the viewpoint of the saner, more thoughtful workman in the form of a character Job Leigh, who speaks thus to old $\mathrm{Mr}$. Carson, the master:

"If we saw the masters try for our sakes to find a remedy even if they were long about it--eren if they could find no help, and at the end could only say, 'Poor fellows, our hearts are sore for ye; we've done all we could, and we can't find a cure,' we'd bear up like men through bad times."12

Mrs. Gaskell says of the masters:

It was clearly their interest to buy cotton as cheaply, and to beat down wages es low as possible. And in the long run the interests of the workmen would have been thereby benefited. Distrust each other as they may, the employers and the employed must rise or fall together. There nay be some difference as to chronology, none as to fact. But the masters did not choose to make all these circumstances known. They stood upon being the masters, and that they had a right to order work at their own prices, and they believed that in the present depression of trade, and unemployment of hands, there would be no great difficulty in getting it done.. So class distrusted class, and their want of mutual confidence wrought sorrow to both. The masters would not be bullied, and compelled to reveal why they felt it wisest and best to offer only such, low wages; they would not be made to tell that they were even sacrificing capital to obtain a victory orer the continental manufacturers. And the workmen sat silent and stern, with folded hands, refusing to work for such pay. 3

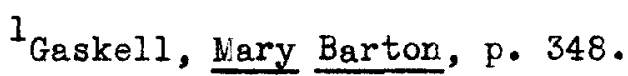

${ }^{2}$ Ibid., p. 365 .

Ibid., pp. 161-162.
} 
But by the time North and South was written, in 1854, Mrs. Gaskell not only has become more friendly toward the capitalist, but she can reason the question more clearly, and she can see that England is trying to help and to treat the laborer fairly. The repeal of the corn laws has overcome the dire poverty of the "hungry forties" and the condition of the leborer has improved to some extent with the widening interest in factory legislstion. The picture she paints in this book, therefore, is not nearly so pathetic and hopeless as that in her first novel. Her aim now seems to be to carry on the good work, and she strives to present all sides of the question fairly and squarely. There is a saner view of the workingman, of the master, of the trade union, and one who comes from the more favored leisure class of the south is the connecting link.

The author creates for her heroine a lovely young woman, the daughter of a clergyman, who comes to the north to live. She is courageous in the face of many doubts and shadows. The just but determined manufacturer meets and loves her, and tries to explain his ideas to her. She is inclined to sympathize with the laborers, and questions repeatedly the monetary standards around her in this manufacturing city.

Mrs. Gaskell shows how largaret Hale, the outsider, sees the north, the industrial section of England, as a place where everything is tested by the standard of wealth; she sees the individual victims, and realizes that there are two classes of people mutually dependent, yet mutually opposed. All this slavish obeisance to wealth is repugnant to Mrs. Gaskell, who had come, herself, from the south, and she uses the character of Nargaret Hale as an outlet, for the feelings, emotions, and questionings that, as a young clergyman's wife, strove within her heart when she first came to the north to live. The author uses this character as a 
basis for allowing the reader to understand both sides of the struggle, for she has both master and worker discuss with Margaret Hale their difficulties with the factory system. The worker's opinion of the master is not very different, in this novel from that of the book written seven years before. Higgins is the name given by the author to the workman of average ability and intellect. She has him say concerning the masters:

"They'd tell us to mind our own business, and they'd mind theirs. Our business being, yo' understand, to take the bated wage, and be thankful; and their business to bate us down to clemming point, to swell their profits.. . I'll tell yo' it's their part,--their due, as some folks call it--to beat us down, to swell their fortunes; and it's ours to stand up and fight hard-not for ourselves alone, but for them round about us--for justice and fair play. we help to make their profits, and we ought to help spend 'em."I

On the other hand, she pictures the capitalist, Thornton, as a self-made man who believes that any of the workers by will power can become leaders in the factory, who feels there is no more need to give his men his reasons for any action on his part than there is need for the servants in the home to be told why there are expenditures or economies in the household budget. The author puts these words in his mouth:

"I maintain that despotism is the best kind of government for them, so that in the hours in which I come in contact with them I must necessarily be an autocrat. I will use my best discretion--from no humbug or philanthropic feeling, of which we have had rather too much in the north--to make wise laws and come to just decisions in the conduct of my business--laws and decisions which shall work for my own good in the first instance-for theirs in the second: but I will neither be forced to give my reasons nor flinch from what I have once declared to be my resolution. Let

IGaskell, North and South, p. 129. 
them turn out: I shall suffer as well as they: but at the end they will find I have not bated nor altered one jot."l

Mrs. Gaskell does not think this the correct viewpoint for the capitalist to have, but she gives it to show the feelings of some of the honest, well-irtentioned capitalists of the day. She stresses the point over and over in both these novels, then, that there is a lack of understanding between the two classes.

That great humanitarian of the nineteenth century, Charles Dickens, in the same year that hrs. Gaskell wrote North and South, penned a biting protest against the materialism of the age, in a novel entitled Hard Times. It is interesting that he and hrs. Gaskell consulted one another about these two novels which were published at first, serially, in Household Words, a periodical which Dickens edited.

The author of Hard Times knew something of factory life, for at the age of ten years, he went to work in a blacking warehouse at Hungerford Stairs.2 In his autobiographical novel David Copperfield, Dickens mentions David's short period of drudgery in lurdstone and Grinley's warehouse. The introduction to the novel states Dickens' antipathy to work in the factory in the following words:

This agony of Dickens' youth appears in heightened colors in Chapter XI of David Copperfield. After reading this chapter, one does not wonder that he never outgrew the grief and humiliation of that period, nor that often in his dreams he wandered desolately back to those gloomy days. 3

In this novel, the story centers around the life and love of the

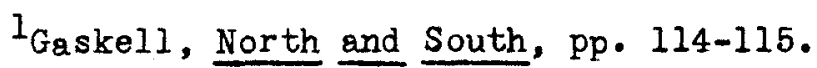

2 Dickens, Charles, David Copperfield, Introduction, p. 31, (Scott, Foreman and Company, Chicago and New York, 1910).

3 Ibid., p. 31 . 
capitalist Gradgrind and his family. The laboring class are represented by two gentle but pathetic creatures, Stephen Blackpool and Rachael. Ihese two love each other but are kept apart by tragic circumstances. These two characters are sympathetically drawn by Dickens, and are so much more realistic than the pompous, fact-loving capitalists Gradgrind and Bounderby, that it is plain that the author's sympathies were entirely on the side of the laboring classes, though he is unsympathetic toward the trade union. Hard Times is a mild satire on those who see facts or figures ano averages and nothing else in the life around them. Dickens does not write in the simple, realistic manner of Mrs. Gaskell, his is an imaginary, exaggerated picture of real life, yet his picture is appealing and pathetic, and convinces the reader that an over-materialistic view is wrong.

This book is noted for its description of the manufacturing town Coketown.

It was a town of red bricks, or of brick that would have been red if the smoke and ashes had allowed it; but as matters stood it was a town of unnatural red and black, like the painted face of a savage. It was a town of machinery and tall chimneys, out of which interminable serpents of smoke trailed themselves forever and ever, and never got uncoiled. It had a black canal in it, and a river that ran purple with ill-smelling dye, and vast piles of building full of windows where there was a rattling and a trembling all day long, and where the piston of the steam-engine worked monotonously up and down, like the head of an elephant in a state of melancholy madness. It contained several large streets all very like one another, and many small streets still. more like one another, inhabited by people equally like one another, who all went in and out at the same hours, with the same sound upon the same pavements, to do the same work, and to whom every day was the same as yesterday and to-morrow, and every year the counterpart of the last and the next...

You saw nothing in Coketown but what was severely workful. If the members of a religious persuasion built a chapel there--as the members of eighteen religious persuasions had done--they made it a pious warehouse of red brick, with sometimes (but this only in highly ornamental 
examples) a bell in a birdcage on the top of it. The solitary exception was the New Church, a stuccoed edifice with a square steeple over the door, terminating in four short pinnacles like florid wooden legs. All the public inscriptions in the town were painted alike in severe characters of black and white. The jail might have been the infirmary, the infirmary might have been the jail, the town-hall might have been either, or both, or anything else, for anything that appeared to the contrary in the graces of their construction. Fact, fact, fact everywhere in the material aspect of the town;

fact, frct, fact everywhere in the immaterial.1

Hard Times is certainly not among the greatest of Dickens' novels, despite the effective description, but it is the only one with the factory as a setting, and two of the leading characters, Gradgrind and Bounderby, capitalists. Dickens makes Bounderby a self-made man who rose by his own efforts, he said of himself, from vagabond to errand boy, to Iaborer, to porter, to clerk, to chief manager, to small partner, to merchant, to banker, to manufacturer.

There was very little in the training of Josiah Bounderby, or any of his class to make them humane employers of labor-and among the several causes which made the early relation of employer and employee under the factory system one of bitter strife, this cause, so strictly social in its origin, is one of the most important.2

Dickens makes this boastful, self-rade man feel that what he could do to gain success every other person could do. And Dickens says of this:

This, again, was among the fictions of coketown. Any capitalist there who had made sixty thousand pounds out of sixpence, always professed to wonder why the sixty thousand nearest Hands didn't each make sixty thousand pounds out of sixpence, and more or less reproached them every one for not accomplishing the little feat. What I did you can do. Why don't you do it? 3

He has Gradgrind and Bounderby say of these workers that they would get drunk, take opium, resort to low haunts, and be

${ }^{1}$ Dickens, Charles, Hard Times, pp. 26-27, (The Nelson Classics, No. 28, Thomas Nelson and Sons, London, Edinburgh, New York, and Paris, n.d.).

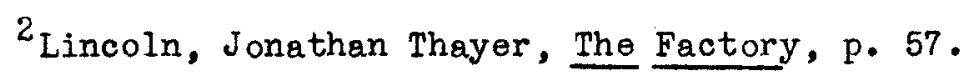

3 Dickens, Hard Times, p. 28. 
"a bad lot altogether, gentlemen; that do what you would for them they were never thankful for it, gentlemen; that they were restless, gentlemen; that they never knew what they wanted; that they lived upon the best, and bought fresh butter, and insisted on Mocha coffee, and rejected all but prime parts of meat, and yet were eternally dissatisfied and unmanageable." 1

Dickens' picture of the self-made master is more disgusting to the reader than lirs. Gaskell's picture of Thornton.

Probation (1880) by Jessie Fothergill gives the picture of one of the kindliest manufacturers. The story opens in 1880 at a time when Lancashire masters, and men also, were independent, proud, and happy. But the years 1862 and 1863 brought famine and suffering because of scarcity of cotton,

and nothing was said about the over-production of the last plethoric year, nor of the piledup goods in the overstocked warehouses.2

The workers seemed to realize the masters were not wholly at fault, for the author shows that the people stoically endure their suffering and even accept relief, a bitter pill to a Lancashire mill-hand. The millowmer did all he could to avert disaster, for Miss Fothergill has him pay wages to the men even when the mills were forced to close. But she does have her superior workman, Myles Heygood, protest bitterly, not against the mill-owner, but against the Radicals in Parliament,

"a pampered set of $\mathrm{rich}$ men who never had a care in their lives, but don't mind how many other people have to bear. There are some, now--Bright and Cobden, and the like--for them I'd die. There's that in their faces which say they have not a mean thought, nor a desire but for our good; but most of them'--he shrugged his shoulders--'those lily-handed politicians who call themselves Radicals in these days, and plan how to prevent a working-man from getting his beer, but

${ }^{1}$ Dickens, Hard Times, p. 28.

2 Fothergill, Jessie; Probation, p. 15, (R. F. Fenno and Company, New York, 1880). 
have half a dozen sorts of wine at their ow tables, and go mincing about at public meetings, talking lightly of trials that would make them cringe if they had to face them, talking about supply and demand and how to improve the conditions of the lower orders--isn't that the phrase? Much they know about the lower orders, and how to improve them! They don't know what ails them yet!"I

In the twentieth century, in 1912, John Edward Patterson had even the labor agitator put in a good word for the masters:

The masters were not all bad, he said--heedless of all the dissent--far from it. They were, in a way, victims with the others, though they did not suffer so much. Class differences and distinctions all the world over, were merely the chance, unorganized growth of centuries of circumstances. It was not the individuals who were wrong, but the whole system . . It was new reasoning to his hearers; but, for the most part, they took it in and believed.. His was evidently not a gospel of pulling down, so much as of lifting up--a natural levelling both ways . . a justice on both sides.2

Patterson, then, in this Story of Stephen Compton, tries to be fair toward both sides.

Mrs. Gaskell, in North and South, shows Thornton worried by competition with the cheap production on the Continent. For his ow interests, he must either shut the factory temporarily, or lower wages, The latter course seems the best for all concerned. The author feels that he is not to be blamed for such a decision, but that he ought to explain the situation to the workers so they will not feel misused. Since the novelists show that this explanation is not made, the opposing sides of capital and labor cannot be conciliated, and the result is either a strike on the part of the workers, or a lock-out on the part of the masters.

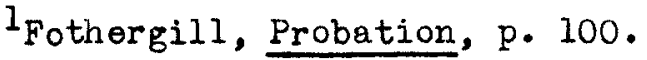

${ }^{2}$ Patterson, John Edward, The Story of Stephen Compton, pp. 66-67,

(George H. Doran Company, New York, 1912).
} 
The novelists state some of the reasons why the workers felt that a strike was necessary. Mrs. Gaskell, in Mary Barton, the earliest novel on this subject, shows that it was lack of work and dire poverty that forced the issue. She has John Barton say:

"I want work, and it is my right." I

A little farther in the book she states that the masters forgot that the strike was in this instance the consequence of want and need, suffered unjustly, as the endurers believed; for however insane, and without ground of reason, such was their belief.2

Little reference is made by the authors to the laborers striking for shorter hours. Mention is made of a strike being called, however, not because of poverty, or the need for money, but because the union believed a strike was necessary. In North and South Mrs. Gaskell has one of the workmen say:

"It's not that we want their brass so much this time, as we've done many a time afore. We'n getten money laid by; and we're resolved to stand and fall together; not a man on us will go in for less wage than th" Union says is our due." 3

Another novelist, Charles Reade, in his book Put Yourself in His Place (1870), gives a monetary reason for the strike and bemoans the fact that:

Indifferent to life, health, and happiness, they could nevertheless be inflamed about six-pence a week. In other words, the money-price of their labor was everything to them, the blood-price nothing. 4

When the masters saw that trouble was imminent, they met to discuss what joint action to take that they might conquer the laborer.

IGaskell, Nary Barton, p. 107.

Ibid., p. 170 .

3 Gaskell, North and South, p. 129.

${ }^{4}$ Reade, Charles, Put Yourself in His Place, p. 106, (A. L. Burt Company, New York, n.d.) 
Mirs. Gaskell in Mary Barton summarizes the owner's meeting:

There might be about twenty gentlemen in the room, including some by courtesy, who were not immediately concerned in the settlement of the present question, but who, nevertheless, were sufficiently interested to attend. These were divided into little groups, who did not seem by any means unanimous. Some were steadily and vehemently opposed to the dangerous precedent of yielding one jot or one tittle to the outward force of a turnout. It was teaching the work-people how to become masters, said they. Did they want the wildest thing hereafter, they would know that the way to obtain their wishes would be to strike work. Besides, one or two of those present had only just returned from the New Bailey, where one of the turn-outs had been tried for a cruel assault on a poor north-country weaver, who had attempted to work at the low price. They were indignant, and justly so, at the merciless manner in which the poor fellow had been treated; and their indignation at the wrong took (as it so often does) the extreme form of revenge. They felt as if, rather than yield to the body of men who were resorting to such cruel measures towards their fellow-workmen, they, the masters, would sooner relinquish all the benefits to be derived from the fulfillment of the commission in order that the workmen might suffer keenly.1

On the other hand, the various writers picture the workers combin-

ing into unions. Nost of the novelists feel the need for combinations, but are against the methods used. Mrs. Gaskell, in Mary Barton, states:

Combination is an awful power. It is like the equally might agency of steam, capable of almost unlimited good or evil. But to obtain a blessing on its labours, it must be under the direction of a high and intelligent will; incapable of being misled by passion or excitement. The will of the operatives had not been guided by the calmness of wisdom.2

For the trade unions, when they saw discontent was brewing, sent labor agitators to the workmen's meetings to fan the flame. Sutcliffe and Dickens show the agitator as a lazy, dishonest, disgusting creature,

\footnotetext{
1Gaskell, Mary Barton, p. 170 .

${ }^{2}$ Ibid., p. 163.
} 
selfishly working for his own ends. He has a steady flow of language, and is equal to any occasion that calls for stirring the emotions of the men.

Dickens, in disgust with the agitator, says of him:

Judging him by Nature's evidence, he was above the mass in very little but the stage on which he stood. In many great respects he was essentially below them. He was not so honest, he was not so manly, he was not so good-humoured, he substituted cunning for their simplicity, and passion for their safe solid course. An ill-made, high-shouldered man, with lowering brows, and his features crushed into an habitually sour expression, he contrasted most unfavourably, even in his mongrel dress, with the great body of his hearers in their plain working clothes. strange as it always is to consider any assembly in the act of submissively resigning itself to the dreariness of some complacent person, lord or commoner, whom three-fourths of it could, by no human means, raise out of the slough of inanity to their own intellectual level, it was particularly strange, and it was even particularly affecting, to see this crowd of earnest faces, whose honesty in the main no competent observer free frpm bias could doubt, so agitated by such a leader. 1

The agitator repeated so often the fact they were grievously

wronged, Dickens felt, that finally each man felt he was being persecuted, and

considered it incumbent on him to join the rest, towards the making of it better; that every man felt his only hope to be in his allying himself to the comrades by whom he was surrounded; and that in this belief, right or wrong (unhappily wrong then), the whole of that crowd were gravely, deeply, faithfully in earnest,--must have been as plain to any one who chose to see what was there, as the bare beams of the roof and the whitened brick walls. 2

This same writer gives a vivid example of the oratory the agitators used to sway their audiences. He has Slackbridge address the mass assembled in a suffocatingly close hall:

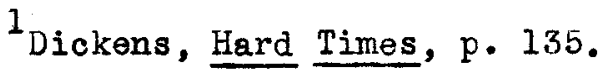

${ }^{2}$ Ibid., p. 135.
} 
"Oh, my friends, the down-trodden operatives of Coketown! oh, my friends and fellow-country-men, the slaves of an iron-handea and a grinding despotism! oh, my friends and fellow-sufferers, and fellow-workmen, and fellow-men! I tell you that the hour is come when we must rally round one another as one united power, and crumble into dust the oppressors that too long have battened upon the plunder of our families, upon the sweat of our brows, upon the labour of our hands, upon the strength of our sinews, upon the Godcreated glorious rights of Humanity, and upon the holy and eternal privileges of Brotherhood:" 1

Wost of the novelists, however, are not against combination, most of them are not even opposed to strikes, but all are opposed to the coercion, the intimidation, and the violence of the trade unions. inrs. Gaskell in wary Barton writes:

As to their decision to work, or not, at such a particular rate of wage, that was either wise or unwise; an error of judgment at the worst. But they had no right to tyrannise over others, and tie them down to their ow procrustean bed. Abhorring what they considered oppression in the masters, why did they oppress others? Because when nen get excited, they know not what they do.2

In North and South this same author shows how the union coerces

and intimidates men. She has the workman Higgins say:

"If a man doesn't belong to th' Union, them as works next looms has orders not to speak to him-if he's sorry or ill it's a' the same; he's out o' bounds; he's none o' us; he comes amiong us, he works among us, but he's none o' us; I' some places them's fined who speaks to him. Yo' try that, Miss; try living a year or two anong them as looks away if yo' look at 'em; try working within two yards o' crowds $o^{\prime}$ men, who, yo' know, have a grinding grudge at yo' in their hearts--to whom if yo' say yo'r glad, not an eye brightens, not a lip moves--to whom if your heart is heavy, yo' can never say nought, because they'll ne'er take notice on your sighs or sad looks (and a man's no man who'll groan out loud 'bout folks asking him what's the matter?)--just yo' try that, Miss--ten hours for three hundred days, and yo'll know a bit what th' Union is,"3

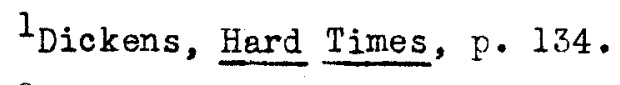

${ }^{2}$ Gaskell, Mary Barton, pp. 162-163.

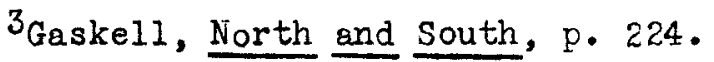


Another still more horrible outgrowth of the unian is the violence of the members to non-union men. One novelist, Charles Reade, wrote a novel in 1870, Put Yourself in His Place, to condemn such practice. In this book he voices a protest against trade unions; he wants to better the conditions for the workmen and to arouse a spirit of self-defense in them; that is, he wants them to strive for more healthy and more sanitary conditions, less dangerous work, and greater happiness; he is against the parsimoniousness of the factory owners, and against their lack of sympathy, of understanding, and of interest in their employees; he bemoans that money is paramount both to owners and to workers. Above all, he is against "rattening" or naiming and torturing victims by union men. His book is a dramatic purpose novel, the story of Henry Little, a well-trained workman from London, an inventor, who is subjected to horrible persecution by the trade union, and cast aside by the capitalist, so that he stands alone, fighting prejudice on all sides. He is a devoted lover to Grace Carden, a lady of high birth, whom he finally wins after rescuing her from a flood. It is enlightening, and it is carefully, faithfully, and realistically drawn.

He believed that the strong situations and sensational events which were the proper substance of the novel should be drawn from records of actual life. To gather such naterial, he became a diligent reader of newspapers and a collector of striking occurrences. He took great pride in this documentation of his fiction, to which he gave the name "matter-of-fact romance"; and when criticized for the improbable character of his incidents, he affirmed, "I feign probabilities. I record improbabilities." Reade thus illustrates a tendency in English fiction which goes back to Defoe and his predecessors, to seek the unusual, the abnormal phases of actual life. 1

His biographer tells of him concerning his preparation for writing

${ }^{1}$ Lovett, R. M. and Hughes, H. F., History of the Novel in England, p. 245, (Houghton Mifflin Company, Boston, 1932). 
this book:

Yet he went down to sheffield, and other manufacturing centres, with a mind impartial and open to conviction. He did not hesitate to fix blame on the masters where he deemed it due; and he expected that either side would recognize the judicial attitude of a writer who had as little liking for the brutality of plutocracy as for the brutality of rattening. 1

It is also interesting to find that the

assassins were so infuriated by his picture of themselves and their dark deeds, that they actually proposed to add him to the number of their victims, and sent him formal notice to that effect. Whether they thought better of it, or whether as they read on they perceived that the author was no more a friend of the tyranny of capital than of the tyranny of labor, and so had the wit to avoid striking a friend in mistake for a foe, we know not.2

Reade shows the method of "rattening" thus: first, a scrawled note is sent as a warning; if no attention is paid, a second note is sent that is even more threatening; then, if no heed is given, they "do" the man, that is, disable him from work by fracturing his skull, breaking an arm, or cutting a sinew of his wrist, or blinding him for life by putting in his work-trough powder which will explode when he builds a fire. Reade says of this:

They have gone as far as shooting men with shot and even with bullet, but never so as to kill the man dead on the spot. They do him. They are skilled workmen, you know; well, they are skilled workmen at violence and all, and it is astonishing how they contrive to stop within an inch of murder. They'll chance it though sometimes with their favorite gunpowder. If you're very wrong with the trade, and they can't do you any other way, they'll blow your house up from the cellar, or let a can of powder down the chimney, with a lighted fuse, or fling a petard in at the window, and they take a chance of killing a housefull of innocent people, to get at the one that's on the black books of the trade and has to be done. ${ }^{3}$

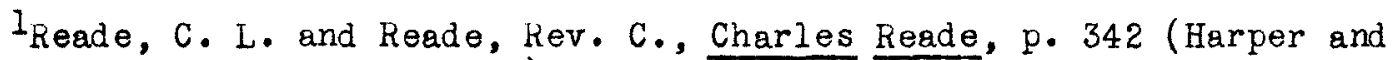
Brothers, New York, 1887).

2 Ibid., p. 341 .

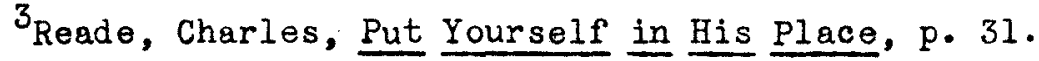


All this the author shows they tried to do at one time or another to the hero of the book, Henry Little, because he did not join the union and received higher wages, though his work warranted better pay. As for the master who paid higher wages to such a man, the author has the foreman say to the secretary of one of the unions,

"if a Ilaster wants his tanks tapped and his hardening-liquor run into the shore, or his bellows to be ripped, his axle-nuts to vanish, his wheel-bands to go and hide in a drain or a church belfry, and his scythe blades to dive in a wheel-dam, he has only to be wrong with your Union, and he'll be accommodated as above."I

Reade shows also that the union will, to all appearances, try to find the culprits and will offer a reward for information, but this is only a blind to keep the public from realizing their underhanded methods. He shows the various methods employed by the press in treating such a subject; he had some papers extremely careful not to lay the blame on the unions, others simply stated bare facts, and still others elaborated the details. Of course, keade shows that it was this last method that aroused the reading public to action. He has so much comment nade concerning Little's treatment by the union that a strike is to be called if Little remains, and, rather than have more trouble, the master lets his fine, staunch workman go. This gives Reade a chance to blame the masters for being so easily intimidated and he has Little say to the workers concerning a master such as this:

"After all, you deserve to win, for you are true to each other; but a master can't be true to a man, nor to anything on earth, but his pocket." 2

Mrs. Gaskell gives a vivid picture of violence by union men when

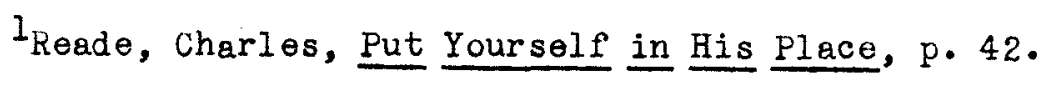

Ibid., p. 42 . 
she has John Barton tell of the results of vitriol being thrown at one of the men who refused to strike:
"none on us would ever throw vitriol again (at least at a knob-stick) if they could see the sight I saw to-day. The man lay, his face all wrapped in cloths, so I didn't see that; but not a limb, nor a bit of a limb, could keop from quivering with pain. He would ha' bitten his hand to keep down his moans, but couldn't, his face hurt him so if he moved it e'er so little. He could scarce mind me when I telled him about Jonas; he did squeeze my hand when I jingled the money, but when I axed his wife's name he shrieked out, 'Mary, Wary, shall I never see you again: Mary, my darling, they've made me blind because I wanted to work for you and our own baby; oh, liary, Mary!" I

In North and South, Mrs. Gaskell shows the worst results of violence as far as the union is concerned, when Higgins states sadly:
"We had public opinion on our side, till he and
his sort began rioting and breaking laws. It were
all o'er wi' the strike then." 2

The leaders in the violence always found that

punishment and suffering were the mutual consequences to those who had taken part in the riot. 3

But vivid accounts in both novels show also that the los for the worker is indeed great. He didn't count the cost it would be to him to see his children begging for bread, and to sit helplessly by while they "clemmed," or starved, to death. In Mary Barton, John's wife, son, and neighbor's twins die for lack of food, heat, and medicine. They sell the furniture, piece by piece, till nothing is left. The author vividly dericts the horrible cellar home where Davenport dies for want of necessities. Mrs. Gaskell also points out another tragedy resulting from strikes when she

\footnotetext{
1Gaskell, Mary Barton, p. 178 .

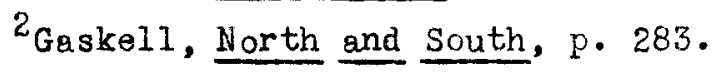

3 Ibid., p. 181 .
} 
shows Barton, and others, taking opium to deaden the pangs of hunger so that more food will be left for their loved ones. In North and South she shows how the men often take to drink to forget; how they spend money in this way to deaden their sorrows instead of buying a little bread for their families. She shows how Boucher, drunk, falls into a ditch full of water and is drowned, and his wife and little ones are left without provision.

Then virs. Gaskell turns to the master. He also loses. The strike had kept Thornton from

$$
\begin{aligned}
& \text { completing some of the large orders he had then on } \\
& \text { hand. He had locked up a good deal of his capital } \\
& \text { in new and expensive machinery, and he had also } \\
& \text { bought cotton largely, for the fulfilment of these } \\
& \text { orders, taken under contract. That he had not been } \\
& \text { able to complete them, was owing in some degree to } \\
& \text { the utter want of skill on the part of the Irish } \\
& \text { hands whom he had imported; much of their work was } \\
& \text { damaged and unfit to be sent forth by a house which } \\
& \text { prided itself on turning out nothing but first-rate } \\
& \text { articles.l. }
\end{aligned}
$$

All of this evidence shows that the novelists believe that, eren though the laborer does have cause for complaint, the strike does not pay since there is a loss to each one concerned. How, then, do the authors attempt to solve the problem of overcoming the antagonism between capital and labor?

Mrs. Gaskell's solution is the one voiced by many of the writers of the early period. She does not really show the reader how the wrongs may be overcome, she does not plan a program for her nation or for the manufacturer to adopt, but she does plead for a sane, Christian viewpoint toward all humanity, for the reader to realize that laborers are persons whose personalities must be respected. She saw the human side of the question and sympathetically, realistically, wins her

\footnotetext{
${ }^{1}$ Gaskel1, North and South, p. 408.
} 
audience to her side. By doing this, she is related to the torch-bearers of Christian socialism in the Victorian period, and because of her wide democracy, she has a place in the progress of her feriod.

She states her stand on the capital-labor question in Mary Barton by showing that old Carson, the master, when he realized his past mistakes, hoped:

That a perfect understanding, and complete confidence and love might exist between masters and men, that the truth might be recognized, that the interests of one were the interests of $a 11$, and, as such, required the consideration and deliberation of all, that hence it was most desirable to have educated workers, capable of juding, not mere machines of ignorant men, and to have them bound to their employees by the ties of respect and affection, not to be mere money bargains alone, in short, to acknowledge the spirit of Christ as the regulating law between both parties. 1

In North and South she paints Thornton as gradually becoming more generous, more open-minded, more just. He learned to consult with

Higgins, the laborer.

Once brought face to face, man to man, with an individual of the masses around him.. . they had each begun to recognize that 'we have all of us one human heart.'2

He tried new experiments for the welfare of his men, consulted them in his plans, such as a dining room for which the provisions wer $\theta$ bought wholesale, and the cost of maintenance equally divided among the men. He found he was more interested in the work because he was benefiting them, and because of his closer contact with these shrewd, ignorant, human people. The author states that by and by he lost all

sense of resentment in wonder how it was, or could be, that two men like himself and Higgins, living by the same trade, working in different ways at the

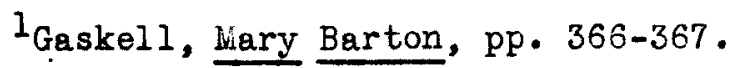

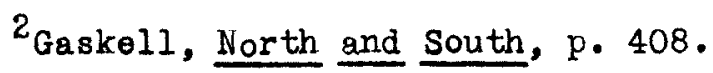


same object, could look upon each other's position and duties in so strangely different a way. And thence arose that intercourse which though it might not have the effect of preventing all future clash of opinions and action, when the occasion arose, would, at any rate, enable both master and man to look upon each other with far more charity and sympathy, and bear with each other more patiently and kindly. Besides this improvenent of feeling both $\mathrm{Mr}$. Thornton and his workmen found out their ignorance as to positive matters of fact, known heretofore to one side, but not to the other.1

Mrs. Gaskell did not think that her solution would clear away all troubles, or that it would end all strikes, but she had Thornton say that such methods

"may render strikes not the bitter venomous sources of hatred as they have hitherto been."2

Dickens offered very little as a way of settling difficulties. He does say that

exactly in the ratio as they worked long and monotonously, the craving grew within them for some physical relief--some relaxation, encouraging good humour and good spirits, and giving them a vent--some recognized holiday, though it were but for an honest dance to a stirring band of music. 3

He does have the workman, Stephen Blackpool, give the various methods that will not settle the trouble:

"The strong hand will never do't. Vict'ry and triumph will never do't. Agreeing fur to mak one side unnat'rally awlus and forever right, and t'other side unnat'rally awlus and forever wrong, will never, never do't. Nor yet lettin alone will never do't. Let thousands upon thousands alone, aw lead in the like lives and aw faw' in into the like muddle, and they will be as one, and yo will be as anoother, wi' a black unpassable world betwixt yo, just as long or short a time as sitch-like misery can last. Not drawin nigh to fok, wi' kindness and patience an' cheery ways, that so draws nigh to one another in their monny troubles, and so cherishes one another

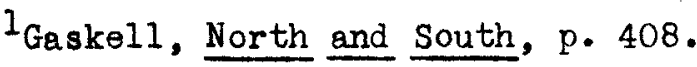
$2_{\text {Ibid., p. } 420 .}$

3 Dickens, Hard Times, p. 29. 
in their distresses wi' what they need them-seln--like, I humbly believe, as no people the genelman ha seen in aw his travels can beat-will never do't till th' Sun turn t'ice. Most $o^{\prime}$ aw, rating 'em as so much Fower, and reg'latin 'em as if they was figures in a soom, or machines-wi'out loves and likens, wi'out memories and inclinations, wi'out souls to weary and souls to hope-when aw goes quiet, draggin on wi' em as if they'd nowt o'th'kind; and when aw goes onquiet, reproachin yo-this will never do't, Sir, till God's work is onmade."I

Dickens, according to this account, would, like Mrs. Gaskell, have masters and men love one another, have them co-operate, and treat each other as human beings. He has Gradgrind change through suffering until he makes

his facts and figures subservient to Faith, Hope and Charity, and no longer trying to grind that Heavenly trio in his dusty little mills.2

And then this writer at the close reminds the reader that this is a purpose novel, by saying in closing,

Dear reader! it rests with you and me whether, in our two fields of action, similar things shall be or not. Let them bel We shall sit with lighter bosoms on the hearth, to see the ashes of our fires turn grey and cold. 3

Reade in his book tries to find some remedy for safeguarding the life of the workman. He drew rules showing first, what the masters could do to help by taking all possible precautions for the safety of the workmen; second, what the workman might do in exercising care and thought for his own safety, how he should strive to keep his children from unhealthy trades where for a small remuneration they learn swearing, drinking, indecency, and how he should prefer spending his money for hot baths, than for gin; and lastly, what the legislature might do by inspection and reports on the unhealthy trades, and on the master's hoedlessness to measures of safety, and by passing acts not allowing children in these dangerous trades. Reade wants Life, Labor, and Capital to go hand in hand, and

\footnotetext{
${ }^{1}$ Dickens, Hard Times, p. 147 .

2 Ibid., p. 283 .

3 Ibid., p. 284.
} 
all cooperate with Legislature. But he also shows that where these measures were carried out, the workmen themselves were unappreciative and discontented, preferring their own methods. He closes his novel by showing that he was not so much striving for a solution as to get the public to realize what was happening:

I have drawn my pen against cowardly assassination and sordid tyranny; I have taken a few undeniable truths, out of many, and have labored to make my readers realize those appalling facts of the day which most men know, but not one in a thousand comprehends, and not one in ten thousand realizes, until Fiction-which, whatever you may have been told to the contrary, is the highest, widest, noblest, and greatest of all the arts--comes to his aid, studies, penetrates, digests the hard facts of chronicles and blue-books, and makes their dry bones live.l

Miss Fothergill, in Probation, has her workman, Myles Heygood, believe that solution to the question would be for the workers to share the master's wealth at his death, rather than to have it pass on to a son who never worked for the money. But the author has the heroine, Adrienne Blisset, a young lady of poor but cultured parentage, question this solution by saying:

"Suppose the arerage working-man became possessed of that money, or of part of it--money which he had not earned-money which had become his by a lucky chance. . . Do you think it would do him a real and permanent good, increase his self-respect, lessen his self-indulgence, make him steadier, soberer, more inwardly dignified, worthy and honorable? . . . Just think what you, a workman, might do, by setting an example to your fellowmen. Take the right side. You are too good for the commonplace career of an ordinary 'intelligent working-man,' for a blind submission to trade-union rules, and for an obstinate resistance to your masters, just because they are your masters, or because your union bids you resist them. Don't be a tool; use your reason; consider the why and wherefore of things. Be answerable to your conscience alone for all you say and do. Help to show your fellows that all improvement in their con-

1 Reade, Charles, Put Yourself in His Place, p. 526. 
dition must arise actively from within, not be received passively from without."I

George Gissing in Thryza, a character sketch of the joys and sorrows of a superior factory girl, paints a scheme by which a cultured manufacturer's son, Egremont, strives to raise the standards of a few outstanding workmen, and thus, slowly, as the years pass, help more and more of the workers. He states his idea in these words:

"What I should like to attempt would be the spiritual education of the upper artisan and mechanic class. At present they are all but wholly in the hands of men who can do them nothing but harm--journalists, socialists, vulgar propagators, of what is called free thought. These all work against culture, yet here is the field waiting for the right tillage. I often have in mind one or two of the men at our factory in Iambeth. They are well-conducted and intelligent fellows, but, save for a vague curiosity, I should say they live without conscious aim beyond that of keeping their families in comfort. They have no religion, a matter of course; they talk incessantly of politics, knowing nothing better, but they are far above the gross multitude. I believe such men as these have a great part to play in social development--that, in fact, they may become great social reformers, working on those above them-the froth of society-no less than on those below... Now suppose one took a handful of such typical men and tried to inspire them with a moral ideal. At present they have nothing of the kind, but they own the instincts of decency, and that is much. I would make use of the tendency to association, which is so strong among them. They have numberless benefit clubs; they stand together resolutely to help each other in time of need and to exact terms from their employers . . . Why shouldn't they band for moral and intellectual purposes? - . . It seems to me that if I can get them pure and simple, without a thought of political or social purposes--especially without a thought of cash profit, which is so disastrously blended with what little knowledge they acquire--I shall be on the way to founding my club of social reformers. I shall be most careful not to alarm them with hints that I mean more than I say. Here are certain interesting English books; let us see what they are about, who wrote them, and why they are deemed excellent. That is our position. These men must get on a friendly footing with me. Little by little I shall talk with them more familiarly, try to understand each one. Success depends upon my personal influence. I may find that it

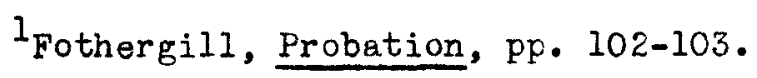


is inadequate, yet I have hope. Naturally, I have points of contact with the working class which are lacking to most educated men." 1

But this idea is unsuccessful, because, save for one unusual workman, the men are satisfied with their lot, and are not anxious to change. Gissing has a wealthy business man say of Egremont as a social reformer:

"Social reform, pooh: Why, who are the real social reformers? The men who don't care a scrap for the people, but take up ideas because they can make capital out of them. It isn't idealists who do the work of the world, but the hard-headed, practical, selfish men. A big employer of labour'll do more good in a day, just because he sees profit'll cone of it, than all the mooning philanthropists in a hundred years. Nothing solid has ever been gained in the world that wasn't pursued out of self-interest.2

James G. Adderly wrote Paul Mercer (1897) to show a priest's efforts to aid the degenerates and unfortunates of East End London by building for them a refuge and by teaching them to share and work together for the comrnon good. The hero who has become interested in this understanding, suddenly, on his father's death, becomes a millionaire with a large factory commity on his hands. The author in the last chapter, has him build a model factory and a nodern community carried forward on the principal of all sharing equally for the common good.

These nineteenth century writers, then, offered little real help for the problem; their purpose was mainly to awaken the slumbering public to their responsibility toward these down-trodden workers.

A twentieth century writer, John Edward Patterson, goes a little further in his thinking. The Story of Stephen Compton is the story of an industrious youth who rises from newsboy to factcry worker to inventor, to labor leader, to capitalist, to politician, all the while striving for solidarity between capital and labor. Through his struggle he is hindered

\footnotetext{
IGissing, George, Thyrza, pp. 14-16 (E. P. Dutton and Company, New York, 1887).

2 Idid., p. 140.
} 
by a profligate brother and helped by a high-principled young woman whom he finally marries.

Patterson voices the idea of silencing strikes by letting the workers share in the profits, by having a system of bonuses. He has his hero go up and down the land praaching this new industrial doctrine.

There ought to be no more strikes for increased pay, he said repeatedly, nor for shorter hours, but every worker in the kingdom should at once come out for a fair return from the profits of his labour--and stay out till he got it, even if he starved to death in doing so. It was the panacea for all wage-troubles. It would make employers and operators co-workers with one mutual end and interest. It would do away with competition and animosity between masters and men, would bring a general feeling of brotherhood into all industries; therefore it was the duty of the State authority to bring it into being without further delay; and if the State did not do so, then it was the business of every worker to stand idle till it was done.1

Fatterson wanted to tear down the old order of industrialism and rebuild it on a more humane, more nearly equal basis. He believed the State should establish a system of mationalizing the houses so that there would be no "jerry building" or building houses merely to sell them above cost, and no slum landlords. He knew that he would be accused of being socialistic in his tendencies, so he has steve state that his is an idea not of Socialism, but of Brotherhood, and explain the differenc $\theta$ in these words:

"Brotherhood carries no sense of equality except that of comradeship. Socialism is a beautiful impossibility-an alluring vision that draws otherwise able men from a possible Niddle course that would eventually lead to a happy and permanent marriage between capital and labour. I have now come to the conclusion that Socialism would only be possible where all men were born with equal abilities, equal chances, equal passions and equal virtues. But while there is aspiration in human blood, intelligence and

\footnotetext{
${ }^{1}$ Patterson, John Edward, The Story of Stephen Compton, p. 135.
} 
stupidity in different minds and unequal opportunities in all men, there can be no true equality even in a community."1

Lastly, Patterson believed that it was largely due to the middleman that difficulties occurred, and steve preaches:

"Co-operate, and let the manufacturer carry his goods in every case to the consumer. It is not so much the producer as the middleman who is the cause of industrialism. The whole system is wrong; and some persons must suffer while that system is being. changed for a better one; it always has been so in every trade and nation and it must be so until industrialism becomes a matter of permanent peace to all concerned in any one nation." 2

With the exception of Sutcliffe, each of the novelists discussed in this chapter is writing about labor conditions as they existed in his own day, and therefore writes from his own experience or observation. Each novelist gives a slightly different interpretation, but all are based on the one word:co-operation. Each author is undoubtedly in earnest. Most of the writers show a sense of justice and a love for all classes that not only helped them understand, without prejudice, both sides of the question, but aid the reader to understand the magnitude of the capitalist-labor problem. Some give worthwile suggestions, others offer little tangible aid, but all want both sides to join hands and together shoulder responsibilities. By getting the reader to think about the question, by laying the facts before him, and by making him realize the great need in this field, the novelists have accomplished the purpose for which they wrote.

1 Patterson, The Story of Stephen Compton, p. 276. ${ }^{2}$ Ibid., p. 312. 
CHAPTEK IV

The Problem of the Literary Effectiveness of the Novels 
CHAPTER IV

The Problem of the Literary Effectiveness of the Novels

The three problems discussed thus far have dealt with an analysis of different aspects of the factory system. There remains the problem of the literary effectiveness of the novels. There are three questions to consider: (1) what was the effect when they appeared? (2) what is their inherent literary value? (3) what is their availability today?

It is impossible for me to say much about the effect they had at the time of publication since but few materials are accessible to me.1 However, the magazine articles listed would lead to the inference that Nary Barton, North and South, Shirley, Hard Times, John Halifax, and Put Yourself in His Place were well received in their day. "Alfred," as was mentioned in the second chapter, remarked that Michael Armstrong and Helen Fleetwood were useful.2

This contemporary judgment corresponds with my analysis of the inherent literary values. I shall give this in terms of setting, story movement, and characterization.

Practically all of the novelists are most successful in their treatment of the setting. Each novelist seems to have striven to present the factory environment in such a manner that the reader's imagination will be stirred, his attention gained, and his sympathy aroused. Most of the writers present the scene by means of contrast. For example, Mrs. Trollope

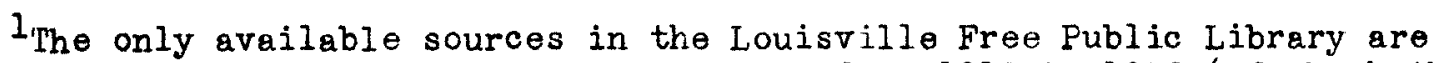
Poole's Guide to Periodical Literature from 1815 to 1906 (of which the years from 1815 to 1881 are accounted for only by an abridged volume), and A Reader's Guide to Periodical Literature from 1900 to the present year. Of the few articles listed at the time of the appearance of the novels, none are available, either because the library files are incomplete, or because the volumes were damaged in the recent flood.

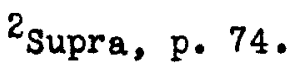


in Michael Armstrong contrasts the home of the mill-owner with that of the factory boy; Mrs. Tonna in Helen Fleetwood contrasts life in a rural community with life in a manufacturing city; Mrs. Gaskell begins her novel Mary Barton by describing a little grassy field two miles from Wanchester where the workpeople went on holidays, and she thus heightens the sordidness of their living conditions in the city. In North and South this same writer employs contrast to even greater lengths by describing life in the rural communities of Southern England with life in the manufacturing cities of Northern England. Mention has already been made of Dickens' noteworthy description of Coketown in Hard Times. Probably the best description is that of Charles Reade in the opening pages of Put Yourself in His Place. Before he introduces any of the characters to the reader, he contrasts the two places where the action of the story takes place, that is, the manufacturing town where it is almost death to breathe the foul air, and the idyllic country village with its pure air and lovely hills and rills. He draws such a strong contrast that the reader can almost picture the differing looks and attitudes of the inhabitants of these two towns, and he sympathizes with anyone who is compelled to live in the factory town. He gives the setting in these words:

Hill sborough and its outlying suburbs make bricks by the million, spin and werve both wool anc cotton, forge in steel from the finest needle up to a ship's armor, and so add considerably to the kingdom's weal th.

But industry so vast, working by steam on a limited space, has been fatal to beauty: Hillsborough, though built on one of the loveliest sites in England, is perhaps the most hideous town in creation. All ups and downs and back slums. Not one of its wriggling, broken-backed streets has hand some shops in an unbroken row. Houses seem to have battled in the air, and stuck wherever they tumbled down dead out of the melée. But worst of all, the city is pock-marked with public-houses, and bristles 
with high round chimneys. These are not confined to a locality, but stuck all over the place like cloves in an orange. They defy the law, and belch forth messy volumes of black smoke, that hang like acres of crape over the place, and veil the sun and the blue sky even in the brightest day. But in a fog,--why, the air of Hillsborough looks a thing to plow, if you want a dirty job.

Nore than one crystal stream runs sparkling down the valleys, and enters the town; but they soon get defiled and creep through it heavily charged with dyes, clogged with putridity, and bubbling with poisonous gasses, till at last they turn to mere ink, stink, and malaria, and people the churchyards as they crawl.

This infernal city, whose water is blacking and whose air is coal, lies in a basin of delight and beauty, noble slopes, broad valleys, watered by rivers and brooks of singular beauty, and fringed by fair woods in places; and, eastward, the hills rise into mountains, and amongst them towers Cairnhope, striped with silver rills, and violet in the setting sun.l

The literary setting is, then, the strongest feature while the story movement is the weakest. The reader's attention soon wanders because he finds himself "preached" at. Particularly at fault on this point is the narrative Nanchester Strike and the novels Helen Fleetwood, Michael Armstrong, Put Yourself in His Place, Bond Slaves, David's Loom, and The Story of Stephen Compton. The first mentioned novel is the most objectionably didactic. Bond Slaves suffers also because of the author's minute attention to historical accuracy. Put Yourself in His Place would suffer greatly from its author's rambling asides were it not for its dramatic action.

Mrs. Gaskell, alone, has found artistic means of surmounting this difficulty, for in wary Barton, she weaves the protest into the story by making the characters give much of the comment. However, her protest is as vigorous as the other rovelists. In fact, she had to soften her

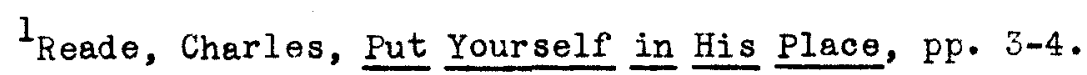


protest in North and South.

Another fault in the story-movement is that it is often mawkish and sentimental. Helen Fleetwood is the most disgusting in this respect. This book overflows with the author's religious views. Never is the reader allowed to lose sight of the error of Catholicism. The Green family syend much of their time at home reading the Bible, singing hyms, praying, preaching against the church of Rome. The reader lays this novel aside with the peculiar feeling that the author has gone to extremes in painting the heroine as a saint persecuted for the sake of her religious views by her fellow workers.

Again, these authors often become too sensational, too dramatic. Wichael Armstrong pictures the wild flight of the heiress from factory to factory, from apprentice house to apprentice house, searching for the little factory boy. Sensational, also, is the death bed scene of the heartless mill-owner. Bond Slaves is also too sensational throughout. The pictures of the secret Luddite gatherings, and the final trial and hanging of the leaders are blood-curdling. Birch Dene is another novel that is too draratic. It opens with the sensational picture of the hero's mother attempting to steal a coat, her detection, her trial, her death, and the lad's consequent attack of mental fever. A little farther in the book westall describes the death of the book dealer and the unscrupulous nephew's hiding of the old man's will. Then he describes, most dramatically, the apprentice house with the stories of the runaway, Blincoe, and the dying child, Harney. The author becomes dramatic again when he unfolds the relationship between Najor Dene and Robin, and also when he describes the mill-owner's flight fron the vengeance-seeking mob of factory workers.

Most sensational writer of all is Charles Reade. In Put Yourself in His Place, the hero's life is constantly endangered, and often he 
escapes only by a hairbreadth. Reade dramatically paints the bursting of the dam, the dynamiting of the reservoir, the galloping of the horse and rider throughout the tow warning the people to flee, the mad, wild rushing of the inhabitants to higher ground, the rising and roaring of the flood-water mercilessly destroying all in its path. This incident Iives before the reader's eyes; the hero, Henry Little, with miraculous effort gets to the girl he loves to save her from the swirling waters. The short phrases, the repetition, the expressive language make the following account of the rescue a masterpiece of description and suspense:

With a loud cry he seized her by her long, floating hair, and tried to draw her in at the window; but the mighty water pulled her from him fiercely, and all but dragged him in after her; he was only saved by clutching the side of the wall with his left hand; the flood was like some vast solid body drawing against him, and terror began to seize on his heart. He ground his teeth; he set his knee against the horizontal projection of the window; and that freed his left hand; he suddenly seized her arm with it; and, clutching it violently, ground his teoth together, and, throwing himself backward with a jerk, tore her out of the water by an effort almost superhuman. Such was the force exerted by the torrent on one side, and the desperate lover on the other, that not her shoes only, but her stockings, though gartered, were torn off her in that fierce struggle. 1

Mrs. Gaskell's story-telling is dramatic, but not sensational. In Mary Barton, her description of the meeting where the workmen decide to vent their wrath on the mill-owner's son is well-written and filled with suspense. It is not sensationally overdrawn but it is given calmly and sympathetically.

Their clenched fists, their set teeth, their livid looks, all told the suffering which their minds were voluntarily undergoing in their contemplation of crime, and in familiarising themselves with its details.

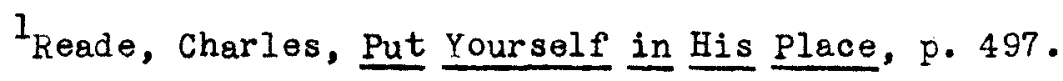


Then came one of those fierce oaths which bind members of trades' unions to any given purfose. Then, under the flaring gaslight, they met together to consult further. With the distrust of guilt, each was suspicious of his neighbor, each dreaded the treachery of another. A number of pieces of paper (the identical letter on which the caricature had been drawn that very morning) were torn up, and one was marked. Then all were folded up again, looking exactly alike. They were shuffled together in a hat. The gas was extinguished; each drew out a paper. The gas was relighted. Then each went as far as he could from his fellows, and examined the paper he had drawn without saying a word, and with a countenance as stony and immorable as he could make it.

Then, still rigidly silent, they each took up their hats and went, every one his own way. I

From this point in the story the author keeps the reader's attention, for after John Barton murders young Carson in fulfillment of the requirements of the meeting where the marked paper was drawn, he goes to Glasgow. Jem Wilson, the one Mary Barton loves, is accused of killing the young man because of jealousy over the latter's attention to hary. Jem is arrested, brought to trial, and the reader is afraid an innocent man will pay the penalty. But Mary Barton discovers the marked paper, realizes her father's part in the murder, and is torn between love for her father and love for Jem. She cannot betray her father, but she finally decides that if she can prove an alibi for Jem, he will probably be acquitted. Nary journeys to Liverpool to find a cousin who could witness that Jem was walking along the road from lanchester to Liverpool on the night of the murder. This evidence, which the author has given at the very end of the trial, turns the course of events, and Jem is set free. But Mirs. Gaskell continues to hold the reader in suspense for she has Mary become very 111 and hover between life and death

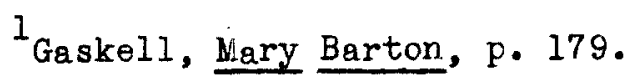


for many days. Finally she returns home to find her half-crazed and dying father there. Before he dies, he acknowledges his guilt and old Mr. Carson finally forgives him. Nary and Jem marry.

There are many opportunities for sensationalism in this story, and, although it is not without emotion, she tells the story in a matter-of-fact manner--simply, appealingly, graphically. The book is filled with pathos and moves quickly and interestingly. This is the best of the factory novels.

In Shirley, Charlotte Brontë tries also to abstain from melodrama and sentimentalism. She draws an interesting picture of Yorkshire life in a small industrial village. This novel shows that the author has tried to give a carefully conceived and sympathetic study of the people of Yorkshire. Her pictures of the moors are poetically painted. It is, however, not easy to read for it is rambling and may be said to have two plots: first, the story of the mill-owner and the influence of the lovely Caroline Helstone on his life, and secondly, the story of Shirley Keeldar, the wealthy heiress, and her love for the tutor, Louis Hoore. Her satire upon the three curates is unnecessary to the story movement and detracts from the beautiful story of Caroline Ilelstone's love for Kobert Moore.

Miss Brontë begins her novel with this statement to her readers:

Do you anticipate sentiment, and poetry, and reverie? Do you expect passion, and stimulus, and melodrama? Calm your expectations; reduce them to a lowly standard. Something real, cool, and solid lies before you; something as unromantic as Monday morning. 1

She does not exclude romance, but she does strive to be matter-offact, yet show the smothered feelings of the working class and as such, appeals to the reader's sympathies.

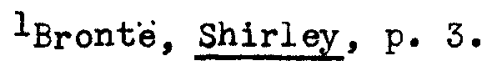


Neither is there any sensationalism in Wrs. Gaskell's other novel, North and South. There are, however, two very interesting scenes; the first is a mob scene outside John Thornton's house. The men are eager to break in the factory doors and wreck vengeance on the mill-owner. Thornton, with arms folded, waits. Mrs. Gaskell then has Margaret Hale rush to Thornton's side and plead with the men to go back home. One ruffian hurls a rock at Thornton; Margaret rushes forward, and the rock hits her in the temple. This causes the mob to file quickly and quietly away.

The second scene that arouses particular suspense concerns the stealthy return of the wayward Hale boy who has long ago been accused of mutiny on ship-board. It is death if he is discovered in England. But the author has Frederick Hale return just in time to bid his mother farewell before she dies. Nargaret and her father dread his discovery. After a few short days at hone, Frederick one dark night, accompanied by his sister, goes to the railway station to start on his journey from his native land. A drunkard, a former sailor friend, recognizes and addresses the Hale boy. Frederick knocks him down, and quickly boards the train. The police follow clues and question Nargaret concerning who killed this drunken man by knocking him down. Thornton intervenes by proving the man died from a disease and not from the blow given by Frederick. While this novel is not quite as interesting as Nary Barton, it is nevertheless, one of the best novels on the factory.

Hard Times, probably because it is by the pen of the well-loved Dickens, is also classed as a better factory nuvel. The story moves quickly from the time Stephen Blackpool is falsely accused by Tom Gradgrind and Bounderby of robbing the bank, until young Tom is forced to acknowledge his guilt and flee for America. There are many pathetic 
pictures in the book such as that of Rachel when the innocent stephen is found, mangled almost beyond recognition and almost dead, in a ditch where he fell a few nights before. Another sad picture is that of Gradgrind's change from a proud, materialistic mill-owner, to a sad, weary, broken-down old man as a result of his son's guilt. This novel is the only one where there is any trace of humor, and even here the slight smile that comes to the reader's face is not as a result of some laughable scene or some Dickensonian character, but only as a result of some little aside of the author. While none of the novels end on a pessimistic note, they are all overflowing with pathos and play upon the reader's sympathy. They are novels of deep, unrelieved human tragedy, and the pictures of human suffering are too dark. They need humor to enliven the picture. Another faulty aspect of the story-telling is the romantic solution. The conclusion of the novel should be impressive and lend emphasis to the whole story. But here the factory novel of ten fails, for the reader closes the book feeling that the author is too idealistic and has forced a happy ending. In many of these novels class barriers are broken. Either the factory worker, after his station has been raised by some financial settlement, marries the heiress as Birch Dene, or the self-made manufacturer, having changed and softened in his attitude toward the working class, marries the cultured or wealthy heroine as in Shirley, North and South, Mistress Barbara, and The Story of Stephen Compton. This is not convincing, but a happy ending was in accordance with the desires of the reading public of thet day, and the authors often responded by raising the fortunes of the central figure through an advantageous marriage.

The characterization is not altogether impossible because of the sympathy it engenders in the reader. This sympathy is aroused first, 
in general, by pity for weak humen beings who are the victims of their environment. They are pathetic figures struggling against defeat, striving merely for self-preservation. Secondly, the reader's sympathy is aroused by strong central characters who rise above untoward circumstances; with these the reader likes to identify himself. But the characterization is weak wherever the sympathy is overdone or where it becomes too one-sided.

The two great weaknesses in the characterization are that the characters are either extremely good or extremely bad, and that there are certain stereotypes. The central figure for the working-class is painted as patient, long-suffering, gentle, forbearing, while the manufacturer is painted as cruel, snobbish, self-righteous, unyielding, money-mad. The working-class are pictured as innocent creatures exposed to unrelieved villainy.

The figures are stereotyped. The children are all over-worked and mistreated, the women haggard and listless; the men restive, given to excessive drinking, smoking, talking. The manufacturer is either a cruel tyrant or a self-made, determined man. The central figure is usually depicted on a pedestal above his fellows. There is usually, also, sone outsider--a person of wealthy influence or culture, sometimes even a relation of the mill-owner himself--who becomes interested in the main character and in the factory people in general, and who is the means of changing the character of the mill-owner.

In spite of these deficiencies, the characters usually contrive to appeal to the reader, and when they speak, reveal feelings and attitudes in a graphic manner. The simplicity of speech of the leading working-class characters arouses pity for the down-trodden, 
while the blunt, harsh speech of the manufacturer arouses disgust for the capitalist class. The use of dialect and colloquial speech, while it presents some difficulties, has the advantage of conveying an intimate understanding of factory people.

It is probably largely because of its splendid character delineation that hary Barton appeals to the reader more than any other of these factory novels. Mrs. Gaskell graphically tells the stories of the helpless class of workers with whom she came in contact on her errands of mercy as a minister's wife. She had accurate knowledge and she was a keen observer. Her leading characters in the book grow gradually either better or worse amid the struggle of Iife: John Barton grows worse step by step, day by day, while his daughter Mary rises, gradually, toward a finer, nobler character. Adversity has affected them just as the reader sees that people in real life are affected. Her book is therefore more realistic, her characters are better drawn than those of other novelists discussed.

The last question concerns the availability of these novels today. What use are they in the twentieth century?

As social documents they are still of considerable interest. This discussion has shown that the novelists' interpretation of the factory development is a plastic counterpart to that of the historian's treatment of factory development.

Few of these novels have risen, however, to the place of classics. Only six of them are still read to any extent in our day. These are: Mary Barton, Shirley, North and South, Hard Times, John Halifax, and Put Yourself in His Place. Most of these are read because they are by well-known authors. Mrs. Gaskell is more famous to-day for her book Cranford than for her industrial novels, Charlotte Brontë for the novel Jane Eyre, Dickens for such novels as David Copperfield, 
Tale of Two Cities, Oliver lwist, and Reade for his Cloister and the Hearth. Even though John Halifax is Mrs. Craik's only well-known book, it is read not because it is an industrial novel, but because of its picture of the nineteenth century middle-class gentlemen. Unless a novel that advocates a contemporary idea tells a story or portrays characters that will be perennially interesting, interest in the book itself will lag when the idea becomes outdated. Too many novels of propaganda have rested their whole case upon the immediate appeal of the idea they are attempting to spread, and their doom has soon been sealed. They survive, if at all, largely as an indication of the thought of the period in which they were written.1

The proletarian writer must feel that these nineteenth century middle-class novelists were sitting comfortably by the fireside, looking out the window on a dreary, unsympathetic world, trying to portray this poverty-stricken humanity, but, not having experienced this struggle themselves, their solution of love, co-operation, benevolence was too idealistic to be workable.

The industrial novelist to-day is more radical. He is either from the working class or from that part of the middle-class which suffered greatly from the depression. He is writing not from a humanitarian motive, but as a result of his own, often bitter, experience.

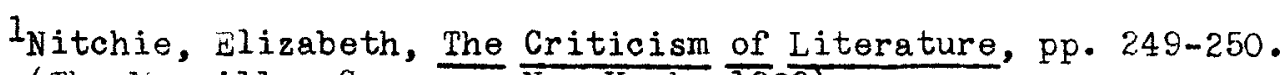
(The Nacinillen Company, New York, $\overline{19} 2 \overline{9}$ ). 
CONCLUSION 


\section{CONCLUSION}

To summarize briefly the results of this study of the factory novel:

(1) It took some time before the experiences of factory ife found literary expression, but when public attention was aroused, the interpretation of the factory in fiction attracted some of the ablest writers.

(2) The outstanding factory problems are covered by the novels though some of them were written many years after the problem was experienced.

(3) As social documents, the factory novels are authentic, and as far as I can judge, effective.

(4) The point of view is characteristically middle-class with their belief in good-will, co-operation, benevolence, and with their humanitarian and sentimental motives. The classic expression of this type of fiction is Mary Barton. 


\section{BIBLIOGRAPHY}

\section{Norels}

Adderly, James Granville, Paul lercer, E. P. Dutton and Company, New York, n.d.

Banks, Mrs. G. Linnaeus (Isabella), A Manchester Man, Abel Heywood and Son, lanchester; Simpkins, Marshall, Hamilton, Hunt and Company, Lond on, 1897

Banks, Mrs. Linnaeus (Isabella), Bond Slaves: The Story of a Struggle, Griffith Farren and Company, London, 1893

Brontë, Charlotte, Shirley, Harper and Brothers, New York and London, 1900

Cleg, John T., David's Loom, or Th' Owd Weighver, Longmans, Green and Company, London, 1894

Craik, Dinah Maria Muloch, John Halifax, Gentleman, A. L. Burt, New York, n.d.

Dickens, Charles, Fard Times, The Nelson Classics, No. 28, Thomas Nelson and Sons, London, Edinburgh, New York, Toronto, and Paris, n.d.

Fothergill, Jessie, Probation, R. F. Fenno and Company, New York, n.d. 
Gaskell, Elizabeth Cleghorn, Mary Barton, Everyman's Library, No. 598, J. M. Dent and Sons, London; E. P. Dutton and Company, New York, first is sued 1911, reprinted, 1924, 1932

Gaskell, Elizabeth Cleghorn, North and South, Everyman's Library, No. 680 , J. M. Dent and Sons, London; E. P. Dutton and Company, New York, first issued 1914, reprinted, 1924

Gissing, George, Thyrza, E. P. Dutton and Company, New York, n.d.

Hamerton, Philip Gilbert, Wenderholme, Roberts Brothers, Boston, 1877

Henty, G. A., Through the Fray: A Tale of the Luddite Riots, Blackie and Son, Limited, London, Glasgow, and Bombay, 1885

Kettle, Rosa M., Mistress of Langdale Hall, T. F. Umvin, Lond on, 1872

Martineau, Harriet, "A Manchester Strike: A Tale" in Illustrations of Political Economy, No. 7, Leonard C. Bowles, Boston, 1833

Naugham, W. Somerset, Liza of Lambeth, Doubleday, Doran and Company, New York, 1936

Patterson, John Edward, The Story of Stephen Compton, George H. Doran and Company, New York, 1912

"Prior, James," (James Prior Kirk), Forest Folk, Dodd, Neade and Company, New York, 1901 
Reade, Charles, Put Yourself in His Place, A. L. Burt Company, New York, n.d.

Saunders, John, Abel Drake's Wife, Lockwood and Company, Lond on, 1862

Sutcliffe, Halliwell, Mistress Barbara, T. Y. Crowell and Company, New York, 1901

Tonna, Charlotte Elizabeth, Helen Fleetwood, Vol. I of Works of "Charlotte Elizabeth," 3 vols., E. P. Dutton and Company, New York, 1845

Trollope, Frances Milton, The Life and Adventures of Michael Armstrong, A Factory Boy, Dodd, Meade and Company, New York, n.d.

Westall, William, Birch Dene, Harper and Brothers, New York, n.d. Westall, william, The old Factory, 3 vols., Chatto and Windus, London, 1881 


\section{Background Material}

Abbott, Willis $\mathrm{J}$. Notable Homen in History, chapters on Frances Wilton Trollope and Harriet Martineau, John C. Winston Company, Philadelphia, 1913

"Alfred" (Samuel Kydd), The History of the Factory Movement (1802-1847), 2 rols., Simpkins, Marshall and Company, Lond on, 1857

Andrew, John B., British Factory Inspection: A Century of Progress in Administration of Labor Laws, U. S. Bulletin, No. 11, 1937

Cambridge History of English Literature, ed. by A. W. Ward and A. R. Waller, Vol. XIII, Part II, Chapt. XI, Nacmillan Company, New York and Lond on, 1933

Cazamian, Louis, Le Roman Social En Angleterre (1830-1850), not translated, Paris, 1903

Cheyney, Edward P., Introduction to the Industrial and Social History of England, pp. 199-312, liacmillan Company, New York and London, 1907

Colson, Percy, Victorian Portraits, pp. 173-223, Rich and Cowan, Lond on, 1932

Dictionary of National Biography, ed. by Leslie Stephen, articles on the lives of Banks, Brontë, Craik, Dickens, Fothergill, Gaskell, Gissing, Hamerton, Henty, hartineau, Reade, Saunders, Tonna, Trollope, Westall, Laomillan Company, New York; Smith Elder and Company, London, first ed. 1885 , supplements in $1901,1912,1927$ 
Dunlop, O. J., and Denman, R. D., English Apprenticeship and Child Labour, A History, pp. 261-350, kacmillan Company, New York, 1912

Encyclopedia of Social Sciences, ed. by E. R. A. Seligman and A. Johnson, articles on "Capitalism," "Christian Socialism," "Corn Laws," "Labor Legislation and Law," "Industrialism," and "Industrial Kevolution," Wacmillan Company, New York, 1935

Engels, Frederick, The Condition of the Working Class in England in 1844, John W. Lovell Company, New York, 1887

Hammond, J. L., and Barbara, The Rise of Modern Civilization,

Harcourt Brace and Company, New York, 1926

Hammond, J. L., and Barbara, The Town Labourer, 1760-1830: The New Civilization, Longmans, Green and Company, Lond on and New York, 1920

Hutchins, B. L., and Harrison, A., A History of Factory Legislation, P. S. King and Son, London, 1918

Lincoln, Jonathan Thayer, The Factory, Houghton Nifflin Company, Boston and New York, 1912

Lovett, R. M., and Hughes, R. F., History of the Novel in England, Houghton Nifflin Company, Boston, 1932

Reade, C. L., and Reade, Rev. C., Charles Reade, Harper and Brothers, New York, 1887 
Sadleir, Michael, Anthony Trollope, Chapters on Frances Milton Trollope, Houghton Mifflin Company, Boston and New York, 1927

Tickner, F. W., Social and Industrial History of England, pp. 510-698, Longman's, Green and Company, New York, London, n.d.

Traill, H. D., Social England, Vols. $V$ and VI, references to factory conditions in the nineteenth century, G. P. Putnam Son, New York, Cassell Company, Limited, London, 1905

Webb, Sidney and Beatrice, The History of Trade Unionism, Longmans, Green, and Company, London, New York, 1894

White, L. A., and Shanahan, E. W., The Industrial Revolution and the Economic World To-day, pp. 39-209, Longman's Green, and Company, Lond on, New York, and Toronto, 1932 


\section{Life}

I was born in Louisville and received my education in the public schools, Louisville Girls Hign School, and University of Louisville. I received my B.A. in 1925, majoring in mathematics and English.

After a year in Louisville Normal School, I was placed in my present capacity as teacher of mathematics at Honsarrat School, Louisville. For a number of years I have been a member of the Wathematics Curriculum Committee and helped to formulate a Course of Study for pupils of low ability.

Graduate work in mathematics not being available in 1930 , I took my major in English and my minor in education. My thesis is a result of my reading Mrs. Gaskell's industrial novels. 